ISSN 2520-2553

\title{
АННАЛИ
}

\section{ЮРИДИЧНОЇ ІСТОРІї}

Том 3. Номер 1-2, січень-червень 2019

Міждисциплінарний науковий журнал 
АННАЛИ ЮРИДИЧНОЇ ІСТОРІї - український періодичний науковий журнал, присвячений проблематиці всесвітньої та вітчизняної історії права. Видається щоквартально у формі тематичних випусків.

Засновники журналу: Міжнародний центр громадянської політологї̈ при Київському національному університеті імені Тараса Шевченка, Львівський медієвістичний клуб при Львівському національному університеті імені Івана Франка.

Журнал індексується в наукометричних базах даних: Slavic Humanities Index (Canada) ma Google Scholar

\section{Головний редактор - В. М. МЕЛЬНИК}

\section{Наукова редакційна рада:}

доктор юридичних наук, професор Т. І. Довнар (Мінськ, Республіка Білорусь)

доктор історичних наук, доцент О. Б. Келлер (Тюбінген, ФРН)

доктор філософських наук, професор Ф. М. Кирилюк (Київ, Україна)

доктор історичних наук, професор А. І. Кудайбергенова (Алмати, Республіка Казахстан)

доктор філософії, професор економіки М. Луптак (Прага, Чеська Республіка)

доктор юридичних наук, професор В. С. Макарчук (Львів, Україна)

доктор історичних наук, професор Я. Г. Рієр (Могильов, Республіка Білорусь)

кандидат юридичних наук, доцент Н. М. Ковалко (Київ, Україна)

кандидат юридичних наук О. В. Середа (Харків, Україна)

кандидат історичних наук, доцент I. Я. Терлюк (Львів, Україна)

\section{Редакційна колегія:}

проф. М. Р. Арпентьєва (Калуга, РФ); доц. О. А. Бакалець (Бар, Україна); ас. О. О. Белов (Вінниця, Україна); доц. А. Г. Бульвінський (Київ, Україна); ст. викл. О. В. Вербова (Гродно, Республіка Білорусь); маг. В. Б. Кіорсак (Львів, Україна); пр. спец. А. В. Лебідь (Москва, РФ); доц. І. М. Ліхтей (Ужгород, Україна); проф. Ф. М. Медвідь (Київ, Україна); проф. К. В. Мезенцев (Київ, Україна); В. П. Петрушенко (Вінниця, Україна); доц. В. В. Сажина (Мінськ, Республіка Білорусь); п.н.с. О. К. Скаленко (Київ, Україна); доц. С. О. Шаляпін (Архангельськ, РФ).

\section{Офіиійний сайт журналу: http://legalhistoryjournal.com.иa}

Журнал публікує наукові статті оглядового і проблемного характеру. До друку приймаються статті, що розкривають актуальні питання історії права, історичної та політичної географії права, історії юридичної філософії, історії політичної і правової думки. Опубліковані статті відображають авторську позицію. Позицію редакції висвітлює вступне слово головного редактора або члена редакційної ради. Журнал особливо вітає на своїх сторінках дискусійні матеріали і приділяє велику увагу наповненню розділу рецензій.

Журнал є учасником проекту «Бібліометрика української науки» Національної бібліотеки Украӥни імені В. І. Вернадського

(C) Авторські права захищено, 2019 
ISSN 2520-2553

\section{АННАЛЫ}

\section{ЮРИДИЧЕСКОЙ ИСТОРИИ}

Том 3. Номер 1-2, январь-июнь 2019

Междисциплинарный научный журнал 
АННАЛЫ ЮРИДИЧЕСКОЙ ИСТОРИИ - украинский периодический научный журнал, посвященный проблемам всемирной и отечественной истории права. Издается ежеквартально в формате тематических выпусков.

Учредители журнала: Международный центр гражданской политологии при Киевском национальном университете имени Тараса Шевченко, Львовский медиевистический клуб при Львовском национальном университете имени Ивана Франко.

Журнал индексируется в наукометрических базах данных:

Slavic Humanities Index (Canada) u Google Scholar

\section{Главный редактор - В. М. МЕЛЬНИК}

Научный редакционный совет:

доктор юридических наук, профессор Т. И. Довнар (Минск, Республика Беларусь)

доктор исторических наук, доцент О. Б. Келлер (Тюбинген, ФРГ)

доктор философских наук, профессор Ф. М. Кирилюк (Киев, Украина)

доктор исторических наук, профессор А.И. Кудайбергенова (Алматы, Казахстан)

доктор философии, профессор экономики М. Луптак (Прага, Чешская Республика)

доктор юридических наук, профессор В. С. Макарчук (Львов, Украина)

доктор исторических наук, профессор Я. Г. Риєр (Могилев, Республика Беларусь)

кандидат юридических наук, доцент Н. Н. Ковалко (Киев, Украина)

кандидат юридических наук О. В. Середа (Харьков, Украина)

кандидат исторических наук, доцент И. Я. Терлюк (Львов, Украина)

\section{Редакционная коллегия:}

проф. М. Р. Арпентьева (Калуга, РФ); доц. А. А. Бакалец (Бар, Украина); ас. А. А. Белов (Винница, Украина); доц. А. Г. Бульвинский (Киев, Украина); ст. преп. О. В. Вербова (Гродно, Республика Беларусь); маг. В. Б. Киорсак (Львов, Украина); вед. спец. А. В. Лебедь (Москва, РФ); доц. И. М. Лихтей (Ужгород, Украина); проф. Ф. М. Медведь (Киев, Украина); проф. К. В. Мезенцев (Киев, Украина); нез. иссл. В. Ф. Петрушенко (Винница, Украина); доц. В. В. Сажина (Минск, Республика Беларусь); вед.н.с. А. К. Скаленко (Киев, Украина); доц. С. О. Шаляпин (Архангельск, РФ).

\section{Сайт журнала: http://legalhistoryjournal.com.иа}

Журнал публикует научные статьи обзорного и проблемного характера. К печати принимаются статьи, которые раскрывают актуальные вопросы истории права, исторической и политической географии права, истории юридической философии, истории политической и правовой мысли. Опубликованные статьи отображают позицию автора. Позицию редакции освещает вступительное слово главного редактора либо члена редакционного совета. Журнал особенно приветствует на своих страницах дискуссионные материалы и уделяет большое внимание наполнению отдела рецензий.

Журнал является участником проекта «Библиометрика украинской науки» Национальной библиотеки Украины имени В. И. Вернадского

(C) Авторские права защищены, 2019 
ISSN 2520-2553

\section{THE ANNALS}

\section{OF LEGAL HISTORY}

Volume 3. No 1-2, January-June 2019

Interdisciplinary Scientific Review 
THE ANNALS OF LEGAL HISTORY - Ukrainian periodic scientific journal devoted to the problems of world and national history of law. Published quarterly in the format of the thematic issues.

Founders of the Journal: The International Centre for Civil Political Science of the Kyiv National University named after Taras Schevchenko, Lviv Medieval Club (at Lviv National University named after Ivan Franko).

The scientific journal is indexed in databases: Slavic Humanities Index (Canada) \& Google Scholar

\section{EDITOR-IN-CHIEF - VIKTOR M. MELNYK (Kyiv, Ukraine)}

Scientificboard:

Dr. Prof. Taisiia I. Dovnar (Minsk, Belarus)

Dr. Prof. Olga B. Keller (Tubingen, Germany)

Dr. Prof. Ajzhamal I. Kudaibergenova (Almaty, Kazakhstan)

Dr. Prof. Fedir M. Kyryliuk (Kyiv, Ukraine)

PDr. Milan Luptak (Praga, Czech Republic)

Dr. Prof. Volodymyr S. Makarchuk (Lviv, Ukraine)

Dr. Prof. Yakov G. Rier (Mogilev, Belarus)

PhD Natalia M. Kovalko (Kyiv, Ukraine)

$\mathrm{PhD}$ Olga V. Sereda (Kharkiv, Ukraine)

PhD Ivan Ya. Terlyuk (Lviv, Ukraine)

Editorial board:

Dr. Prof. Mariiam R. Arpentieva (Kaluga, Russia); PhD Oleksiy A. Bakalets (Bar, Ukraine); $\mathrm{PhD}$ Oleksanr O. Belov (Vinnitsya, Ukraine); PhD Andriy G. Bulvinskyj (Kyiv, Ukraine); Lecturer Olga V. Verbova (Grodno, Belarus); MA Vladyslav B. Kiorsak (Lviv, Ukraine); Researcher Anna V. Lebid (Moscow, Russia); PhD Igor M. Lihtey (Uzhgorod, Ukraine); PhD Prof. Fedir M. Medvid (Kyiv, Ukraine); Dr. Prof. Konstantyn V. Mezentsev (Kyiv, Ukraine); Researcher Viktor P. Petrushenko (Vinnitsya, Ukraine); PhD Varvara V. Sazhina (Minsk, Belarus); Dr. Prof. Oleksiy K. Skalenko (Kyiv, Ukraine); PhD Sergey O. Shalyapin (Arkhangelsk, Russia).

Web-site of the Journal: http://legalhistoryjournal.com.ua

The journal publishes research papers and reviews on the history of law problematic. Journal accept for publication articles which disclose topical issues of the history of law, history of legal philosophy, history of political and legal thought. Published articles reflect the author's position. 


\section{MICT}

\section{ОРИГІНАЛЬНІ НАУКОВІ СТАТТІ}

Олексій Бакалещь (Бар, Украӥна). Метрична книга Свято-Успенської церкви 1839-1855 рр. як джерело дослідження громадянського стану людини в Барському регіоні у 30-50-х рр. ХІХ століття (архівна розвідка) ................10

Олександр Белов (Вінниияя, Україна). Нарис теорії податкової поведінки ...

Юлія Гаврильченко (Мінськ, Республіка Білорусь). Актуальні проблеми сучасного оподаткування: нарис співвідношення публічної і приватної мети

Олександр Кукса (Мінськ, Білорусь). Дипломатичні відносини БНР та уряду Павла Скоропадського

Віктор Мельник (Київ, Україна). Боротьба Візантії за право володіння Італією: історико-юридична характеристика війни 541-552.

Михайло Тупиця (Львів, Украӥна). Утворення і початки функціонування Сяноцього гродського уряду та інтеграція Сяноцької землі до складу Польського королівства в XIV-XV ст. 105

Владислав Сасін (Київ, Україна). Розвиток ідеї народного суверенітету за доби середньовіччя: державний і церковний виміри. 


\section{СОДЕРЖАНИЕ}

\section{ОРИГИНАЛЬНЫЕ НАУЧНЫЕ СТАТЬИ}

Алексей Бакалеи (Бар, Украина). Метрическая книга Свято-Успенской церкви за 1839-1855 гг. как источник по исследованию гражданского состояния жителей Барского региона..........................................10

Александр Белов (Винница, Украина). Очерк теории налогового поведения. .24

Юлия Гаврильченко (Минск, Беларусь). Актуальные проблемы современного налогообложения в контексте соотношения публичных и частных целей.

Александр Кукса (Минск, Беларусь). Дипломатические отношения Белорусской Народной Республики и правительства Павла Скоропадского (1918)

Виктор Мельник (Киев, Украина). Борьба Византии за право владения Италией: историко-юридическая характеристика войны 541-552 гг.

Михаил Тупиця (Львов, Украина). Создание и начало функционирования Саноцкого гродского правления и интеграция Саноцкой земли в состав Польского королевства (XIV-XV вв.).

Владислав Сасин (Киев, Украина). Развитие идеи народного суверенитета в средние века: государственное и церковное измерения. 


\section{CONTENT}

PhD Alexey Bakalets (Bar, Ukraine). THE METRIC BOOK OF THE HOLY-USPENSKY CHURCH FOR 1839-1855 AS A SOURCE FOR THE STUDY OF THE CIVIL

STATUS OF THE CITIZENS OF THE BAR REGION (In Ukrainian) .10

PhD Oleksandr Belov (Vinnitsya, Ukraine). THE THEORY OF TAX

BEHAVIOR: INTRODUCTION (In Ukrainian)

Dr. Prof. Yulia Gaurylchenko (Minsk, Belarus). CURRENT PROBLEMS OF MODERN TAXATION IN THE CONTEXT OF THE RELATIONSHIP OF PUBLIC AND

PRIVATE GOALS (In Russian).

PhD Alexander Kuksa (Minsk, Belarus). DIPLOMATIC RELATIONS BETWEEN

THE BELARUSIAN PEOPLE'S REPUBLIC AND THE UKRAINIAN

STATE IN 1918 (In Russian)

PhD Viktor Melnyk (Kyiv, Ukraine). THE STRUGGLE OF BYZANTIUM FOR

THE RIGHT TO OWN ITALY: HISTORICAL AND LEGAL CHARACTERISTICS

OF THE WAR IN 541-552 AD (In Russian). .65

MA Mykhailo Tupytsia (Lviv, Ukraine). ESTABLISHMENT AND BEGINNING

OF THE FUNCTIONING OF THE SANOK GOVERNMENT AND THE

INTEGRATION OF SANOK LAND TO THE POLISH KINGDOM

IN XIV-XV CENTURIES (In Ukrainian). .105

BA Vladyslav Sasin (Kyiv, Ukraine). THE DEVELOPMENT OF IDEA

OF POPULAR SOVEREIGNTY IN THE MIDDLE AGES: STATE

AND CHURCH VIEWS (In Ukrainian). 
DOI 10.38129/Ann.Yur.Ist.2019.3.1.2.10

УДК 329.532 .3

\title{
МЕТРИЧНА КНИГА СВЯТО-УСПЕНСЬКОЇ ЦЕРКВИ ЗА 1839-1855 pp. ЯК ДЖЕРЕЛО ДОСЛІДЖЕННЯ ГРОМАДЯНСЬКОГО СТАНУ ЛЮДИНИ В БАРСЬКОМУ РЕГІОНІ У 30-50-х РОКАХ ХІХ СТОЛІТТЯ
}

\author{
ОЛЕКСІЙ БАКАЛЕЦЬ (Бар, Україна)
}

Відтворюючи історичну пам'ять, формуючи інтерес до спадщини народу, залучаючи молодь до державного будівництва, український народ, за словами видатного українського історика Ісидора Нагаєвського, «сповняє свою неповторну місію. I чим більше він виростить відданих синів і дочок та творить свою власну духовну і матеріальну культуру, він виконує неповторну історичну місію» $[1, \mathrm{c.2}]$.

Історичні джерела: речові, письмові, усні, зображальні, лінгвістичні, топонімічні відіграють важливу роль в об'єктивному висвітленні української історії, культури, історії церкви, регіональної історії, генеалогічних, релігійних, етнічних процесів. Письмові джерела $\epsilon$ матеріальними носіями письмової інформації про людей та суспільство: літописи, хроніки, житія, грамоти, універсали, скарги, законодавчі акти, ділові документи, метричні та актові книги, статистичні джерела, переписи населення, матеріали соціологічних досліджень, преси, судово-слідчі документи, документи громадських об'єднань та політичних партій, мемуари, записні книжки, приватне листування, подорожні нотатки іноземців, автобіографії, агіографічна, наукова та художня література [1, с. 9].

Відомий історик, вчений, державний діяч, автор магістерської дисертації «Барське староство. Історичні нариси XV - XVIII ст.» (1894 р.) М. C. Грушевський (1866-1934) дав блискучий приклад наукового використання творів давньоукраїнських літописців, зарубіжних істориків, хронік, архівних документів для створення історії українського народу, а також Барського краю [2]. Здійснені дослідником публікації джерел не втратили значення і сьогодні. Плідно сьогодні в цьому напрямку працюють вітчизняні історики-джерелознавці: М. Варшавчик, Л. Винар, В. Смолій [3], М. Котляр, Я. Калакура, І. Войцехівська [5], Ю. Мицик, І. Гирич, М. Дмитрієнко, Л. Дубровіна, В. Сергійчук, В. Солдатенко, Б. Корольов, П. Толочко, В. Даниленко, В. Верстюк, В. Мордвінцев [7; 8], В. Томазов [8; 10], 
Ю. Легун [6], С. Єсюнін [4].

Серед письмових інформаційних джерел вагоме місце займають метричні книги, що містять важливу інформацію про громадянський стан людини (народження, хрещення, вінчання, смерть, відспівування) [3, с. 628]. У 260-у річницю Свято-Успенської церкви міста Бар важливо відкрити сторінки ії історії. В цьому нам допоможе метрична книга, яка велася у церкві з 1838 до 1855 року включно і яка є об'єктом нашого дослідження.

Тривалий час метричні книги, як найцінніше джерело для генеалогічних досліджень певного міста чи регіону, залишалися поза увагою професійних науковців. Такі дослідження, активізовані в незалежній Україні, сприяють введенню до наукового обігу одного із найінформативніших джерел для вивчення і відновлення родоводів [7; 8; 10].

Перші метричні книги на українських землях з'явилися у XVI ст., але систематично і повсюдно їх було запроваджено указом Петра I у 1702 р., а 3 1724 р. Синод затвердив зразок формуляра метричної книги. Їх ведення стало обов' язковим для православних священиків, а також католиків, іудеїв та лютеран. Ці книги вели священики і дяки у двох екземплярах на великих паперових аркушах.

Перший примірник метричної книги відсилався до Духовної консисторії у повітове місто, де підшивався в один великий зведений том за поточний рік.

Другий примірник книги залишався у церкві та зшивався 3 метричними книгами за попередні роки. У межах однієї парафії цілісний том виходив за 15-50 років.

В пропонованому читацькій увазі дослідженні розглядається зміст метричної книги Свято-Успенської церкви заштатного м. Бар Могилівського повіту Подільської губернії, де збереглися записи за 18391855 роки, тобто за 16 років (див. дод. Б!). На 148 сторінках зафіксовано 210 подій (переважно вінчання) 38 січня 1839 р. до 2 жовтня 1855 р. [6].

Записи у даній книзі вели: дяки Петро Козловський (з 8 січня 1839 р. до 27 січня 1844 р.), Євстафій Твуравський (з 19 травня 1844 р. до 2 вересня 1845 р.), Петро Козловський (з 14 жовтня 1845 р. до 29 серпня 1846 р.), Євстафій Твуравський (з 6 жовтня 1846 р. до січня 1850 р.), Сильвестр Куліковський (з 5 лютого 1850 р. до 25 жовтня 1851 р.), Василь Храткович (3 жовтня 1851 р. до 1855 р.).

Частину тексту метричної книги важко прочитати через висихання чорнила та потьоки від потрапляння води на частину сторінок. Але в цілому текст доступний для ознайомлення. На жаль, не збереглися інші 
книги, де містилася цінна інформація про народження, одруження, хрещення, вінчання, смерть та відспівування місцевих жителів.

Своїми підписами завіряли правильність записів у метричній книзі наступні священники Свято-Успенської церкви: Матвій Новіцький у 18391844 рр., Тимофій Страшевский у 1844 р., Василь Кузмінський у 1844-1850 рр., Семеон Карчевський у 1850-1855 рр. [7].

Класичний запис про вінчання (затверджений у 1838 р.) сповіщає повну дату здійснення таӥнства, місце мешкання, соціальний стан, ім'я по батькові, прізвище нареченого та нареченої 3 зазначенням віку, віросповідання та кількості шлюбів для наречених (для нареченої вказується ім'я батька, а в разі попереднього шлюбу - прізвище попереднього чоловіка), місце мешкання, соціальний стан, професію, імена, імена по батькові, прізвища поручителів, імена священника та причту [3, с. 628]. Цих вимог чітко дотримувалися зазначені священики та дяки (див. нижче витяги із книги).

Проаналізуємо деякі записи із метричної книги Свято-Успенської церкви заштатного міста Бар (документи передані мовою оригіналу).

«1839 года Январъ 22 дня по Указу его Императорского Величества г. Бара Успенской Церкви Священноцерковнослужители произвели обыскъ желающих вступить въ бракъ и показалось следуещее: 1. Женихъ крестьянинъ Мартын Николаев Мытковский православного исповедования, проживающий в Могилёвском уезде деревни Войнашовка в приходе сей церкви. 2. Невеста крестьянка Марта Фёдорова Ткачучка того ж исповедования, проживающая в Могилёвском уезде деревни Войнашовка в приходе сей церкви. 3. Возраст къ супружеству имеютъ совершенный, именно: Женихъ 20 лет, а невеста 18 лет, оба находятся въ здравом уме. 4. Родства между ними духовного или плотского и свойства возбраняющего по установлению Св. Церкви брак никакого нет. 5. Женихъ холость, а невеста девица. 6. К браку приступают они по своему взаимному согласию, а не по принуждению и на то имеют от родителей позволение. 7. По троекратному соглашению сделанному в означенной Церкви 1839-го года Января 5, 15 и 22 числа препятствия к сему браку никакого никемъ не объявлено. 8. Для удостоверения беспрепятственного сего брака имеется письменный документъ. 9. По сему бракосочетание означенныхъ лиц предположено совершить сего года Января 22 дня во узаконенное время при посторонних свидетеляхъ. 10. Что всё показанное уж о женихе и невесте справедливо, в томъ удостоверяютъ своей подписью как они сами, такъ и поручители, съ темъ, что если что окажется ложным, то подписавшиеся повинны за то суду по правилам церковным и Законамъ 
гражданскимъ.

Женихъ Крестьянинъ Мартын Николаев Мытковский

Невеста Крестьянка Марта Фёдорова Ткачучка

Поручители со стороны жениха крестьяне деревни Войнашовки: Николай Андреевъ Паращук и Никита Павлов Захарчукъ. Со стороны невесты: Григорий Андреев Ткачукъ и Петр Павлов Захарчукъ крестьяне той же деревни.

Обыскъ сей производили: Свяшенникъ Матвий Новицкий

Дьякъ Пётръ Козловский» [6, с. 5-7].

3 іншого запису про вінчання ми дізнаємося про наступне: «1849 года Августа 26 дня по Указу его Императорского Величества Заштатного г. Бара Успенской Церкви Священноцерковнослужители произвели обыскъ желающих вступить въ бракъ показалось следуещее: Женихъ Винницкого уезда Титулованный советникъ Иванъ Николаевъ Лазавский, Православного исповедования. 2. Невеста Отставного генерал-маёра Антона Иванова Бачинского дочь Юлия Ригина, жительствует въ Хуторахъ. 3. Возраст къ супружеству имеютъ совершенный, именно: Женихъ 33 г., а невеста 16 лет, оба находятся въ здравом уме. 4. Родства между ними духовного или плотского родства и свойства возбраняющего по установлению Св. Церкви брак никакого нет. 5. Женихъ холость, а невеста девица. 6. К браку приступают они по своему взаимному согласию, а не по принуждению и на то имеют от родителей позволение. 7. По троекратному соглашению сделанному в монастырской Церкви 1849 года Августа 20, 22 и 26 числа препятствия к сему браку никакого никемъ не объявлено. 8. Для удостоверения беспрепятственного сего брака имеется письменный документъ. 9. По сему бракосочетание означенныхъ лиц предположено совершить сего года Августа 26 дня во узаконенное время при посторонних свидетеляхъ.

Женихъ Иванъ Николаевъ Лазавский

Невеста Юлия Ригина

Поручители за жениха: помещикъ Стиранъ Маевский, Кочинская Динария и Кавалеръ Думский, по невесте: помещикъ Петр Одвенский, помещикъ Долинский Василий

Свяшенникъ Симеон Карчевский

Протоиерей Василий Кузьмин

Дияконъ Иеофан Тыривский» [6, с. 69].

У третьому документі, датованому 15 жовтня 1850 р. записано: «1850 года Октября 15 дня по Указу Его Импрераторского Величества города Бара Успенской Церкви Священной Церковнослужители производили обыскъ о 
желающих вступить въ бракъ и оказалось следующее: 1. Женихъ Барский мещанинъ Александръ Ивановъ Манита, православный, жительствуетъ в приходе сей Церкви. 2. Невеста Барская мещанка Агнесса Варикова Прохницка Римского обряда, жительствуетъ в приходе Барского Костёла. 3. Возраст къ супружеству имеютъ совершенный, а именно: женихъ 20 лет, невеста 18 лет и оба находятся в здравом уме. 4. Родства между ними духовного или плотского родства и свойства возбраняющего по установлению Св. Церкви брак никакого нет. 5. Женихъ холостъ, а невеста девица. 6. К браку приступают они по своему взаимному согласию, а не по принуждению и на то имеют от родителей позволение. 7. По троекратному соглашению сделанному в монастырской Церкви сего года и октября 1, 8 и 15 дней препятствия к сему браку никакого никемъ не объявлено. 8. Для удостоверения беспрепятственного сего брака имеется письменный документъ. 9. По сему бракосочетание означенныхъ лиц предположено совершить в Монастыре сего года октября 15 дня во узаконенное время при посторонних свидетеляхъ. 10. Что всё показанное уж о женихе и невесте справедливо, в томъ удостоверяють своей подписью как они сами, такъ и поручители, съ темъ что если что окажется ложным, то подписавшиеся повинны за то суду по правилам церковным и законамъ гражданскимъ.

Женихъ Мещанинъ Александръ Ивановъ Манита

Невеста Мещанка Агнесса Ваврикова Прохницка

Поручители за жениха: барские Мещане Андрей Никитинъ Матвеенко и Иванъ Онуфриев Манита, по невесте: Яковъ Ивановъ Ходзинский и бывший крестьянин Успенской юридики Тарасий Яковлевъ Поворознюкъ.

Обыскъ сей производили: Свяшенникъ Симеон Карчевский Дияконъ Иеофан Тыривский» [6, с. 102].

Розглянувши частину записів про одруження із метричної книги Свято-Успенської церкви м. Бара за 1839-1855 рр. можна зробити деякі висновки.

По-перше, нами встановлено, що середній вік «женихів» у Барі та навколишніх селах у 30-50-х роках становив 28 років, а «наречених» - 25 років (враховуючи повторні шлюби для вдів та вдівців) (див дод. В).

По-друге, серед осіб, які укладали шлюб і проходили обряд вінчання, переважають православні і лише декілька разів зафіксовані випадки одруження православних із римо-католиками.

По-третє, у ролі поручителів (свідків) виступають селяни, міщани, офіцери та дворяни, переважно місцеві поміщики (див. дод. Б).

По-четверте, переглянувши прізвища наречених, їх поручителів та 
церковнослужителів, які реєстрували шлюб, можна серед сучасних мешканців міста Бар, сіл Войнашівка, Шпирки, Шершні та інших віднайти подібні прізвища. Приклади: Митковський, Матковський, Попик, Нетупський, Маніта, Прохніцький, Юзвенко, Нікітін, Бортник, Мацюк, Кащенко, Ришовський, Гвоздецький, Блащук, Гуд, Захарчук, Якубчик, Ходзінський, Кремінський, Слободянюк, Ткачук, Барчук, Тихолаз, Царенко, Максімов, Матвієнко, Карчевський, Козловський та інші (див. дод. Г).

\section{Соціальний, національний склад та динаміка чисельності населення} м. Бар Подільської губернії в 1861 - 1913 рр. (за даними С. М. Єсюніна)

\begin{tabular}{|c|c|c|c|c|c|c|c|c|c|c|}
\hline \multirow[b]{2}{*}{ Рік } & \multirow[b]{2}{*}{$\begin{array}{c}\text { Динаміка } \\
\text { чисельності }\end{array}$} & \multicolumn{5}{|c|}{$\begin{array}{c}\text { Становий } \\
\text { склад }\end{array}$} & \multicolumn{4}{|c|}{$\begin{array}{c}\text { Національний } \\
\text { склад }\end{array}$} \\
\hline & & 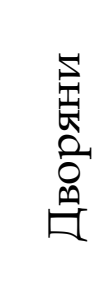 & 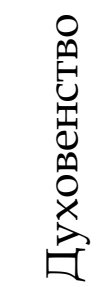 & 宣 & 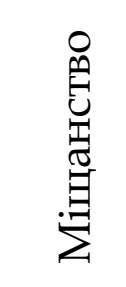 & 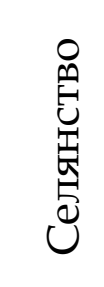 & 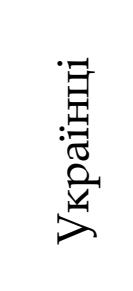 & :ै & 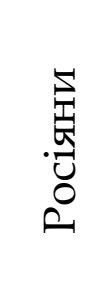 & 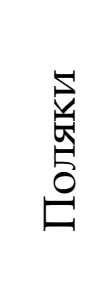 \\
\hline 1861 & 7274 & $\begin{array}{r}133 \\
1,9 \%\end{array}$ & $\begin{array}{c}58 \\
0,8 \%\end{array}$ & $\begin{array}{r}384 \\
5,3 \%\end{array}$ & $\begin{array}{c}6317 \\
86,8 \%\end{array}$ & $\begin{array}{r}194 \\
2,7 \%\end{array}$ & - & - & - & - \\
\hline 1881 & 11566 & - & - & - & - & - & - & - & - & - \\
\hline 1897 & 9982 & $\begin{array}{r}232 \\
2,3 \%\end{array}$ & $\begin{array}{c}48 \\
0,5 \%\end{array}$ & $\begin{array}{c}78 \\
0,8 \%\end{array}$ & $\begin{array}{c}8658 \\
86,7 \%\end{array}$ & $\begin{array}{r}809 \\
8,1 \%\end{array}$ & $\begin{array}{l}3332 \\
33,4 \%\end{array}$ & $\begin{array}{c}5764 \\
57,7 \%\end{array}$ & $\begin{array}{r}485 \\
4,9 \%\end{array}$ & $\begin{array}{c}378 \\
3,8 \%\end{array}$ \\
\hline 1913 & 22663 & - & - & - & - & - & - & - & - & - \\
\hline
\end{tabular}




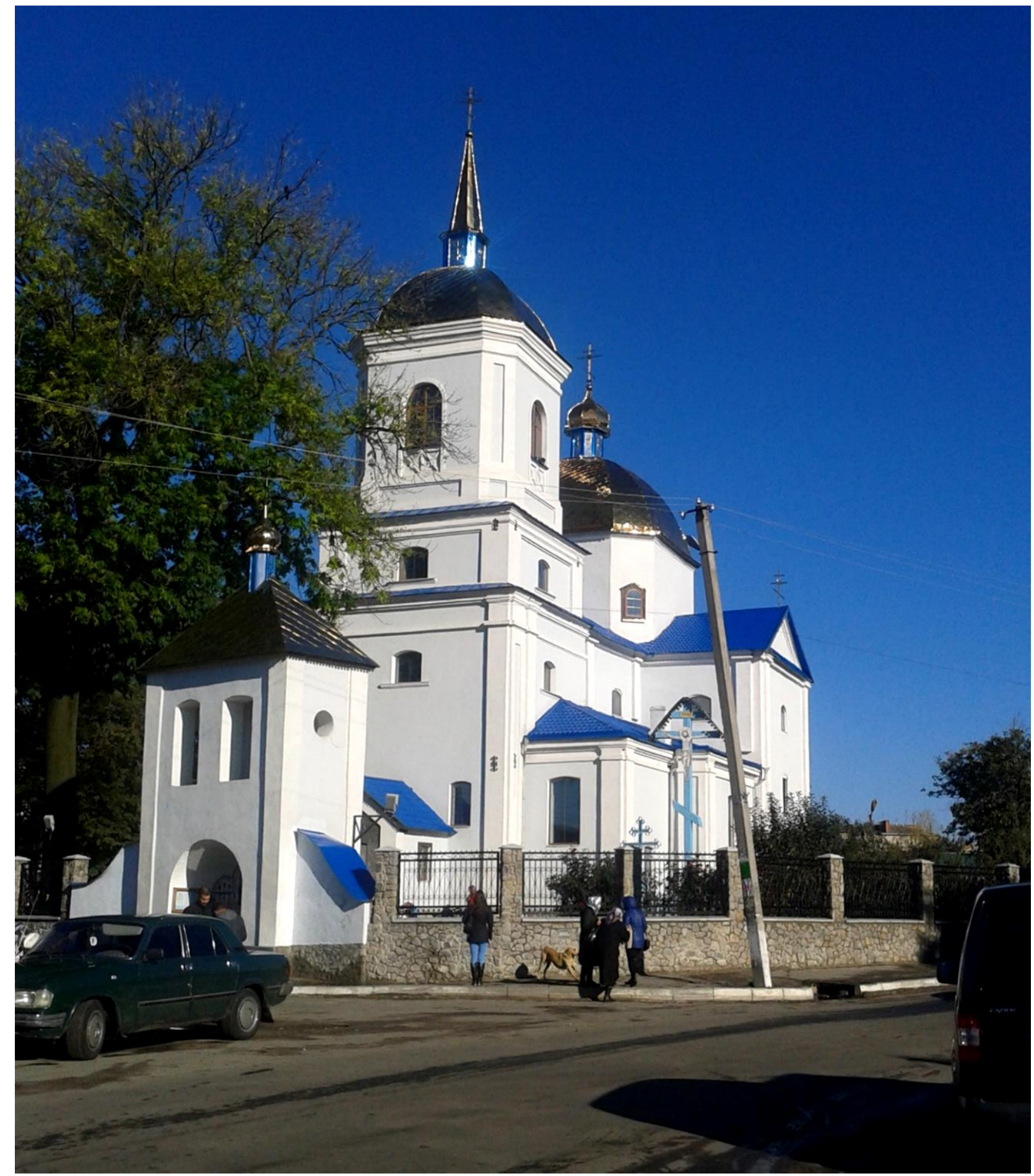




\section{Додаток Б. Запис про реєстрацію шлюбу від 15 жовтня 1850 p. в Свято-Успенській церкві м. Бар Могилівського повіту}

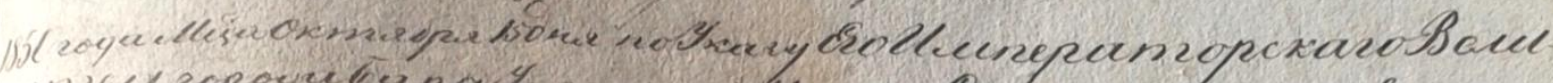

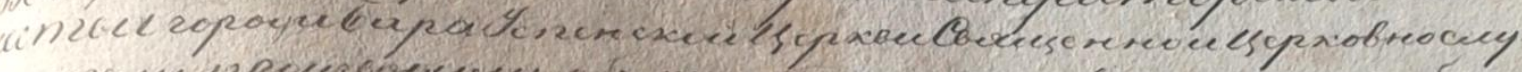

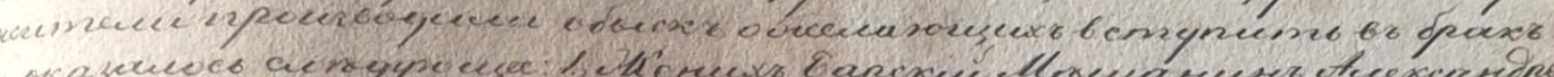

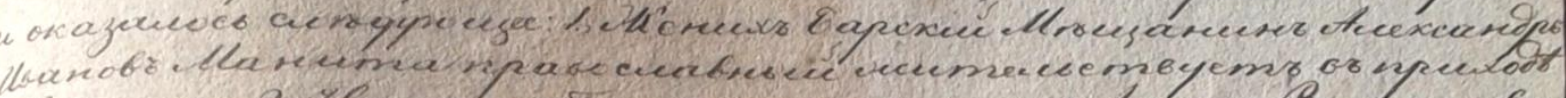

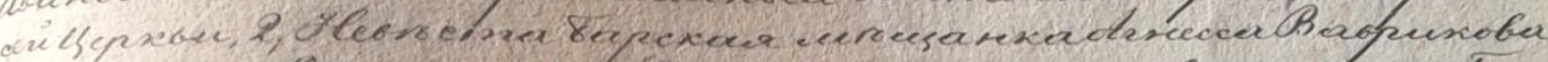

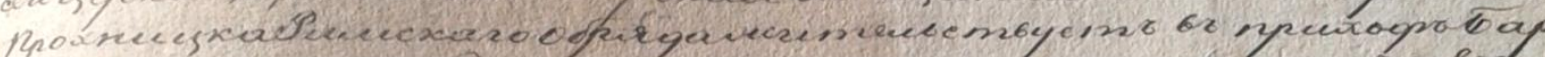

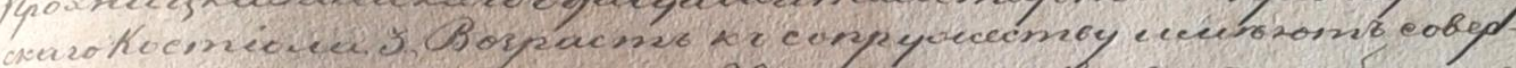

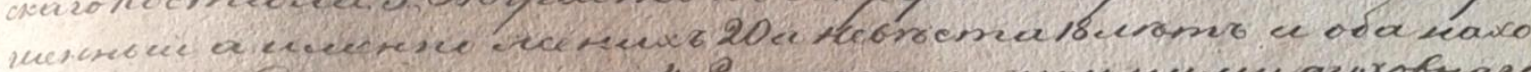

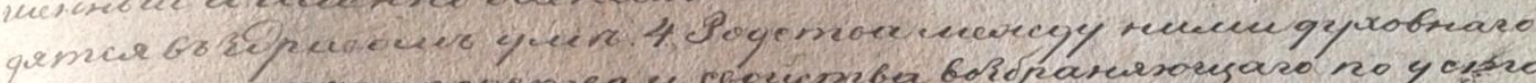

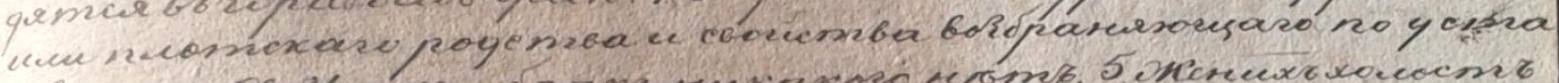

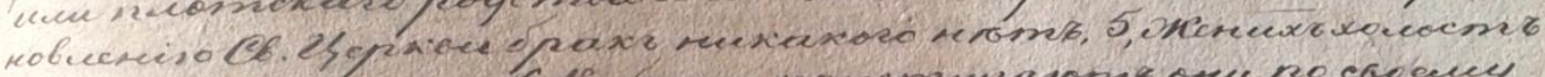

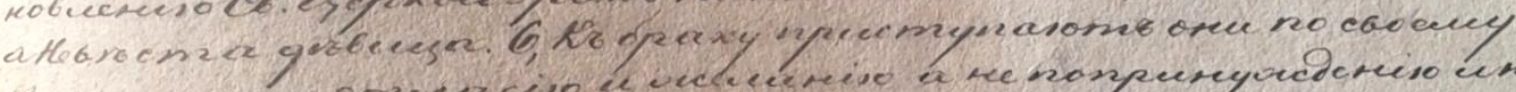

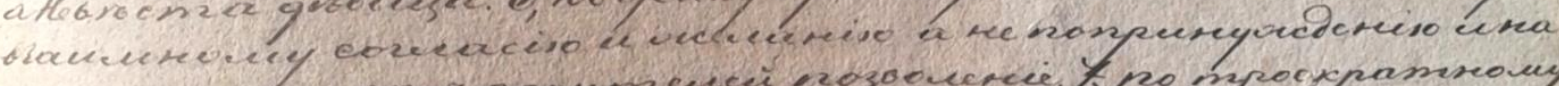
ya

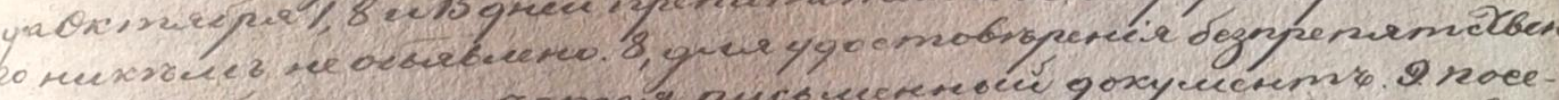

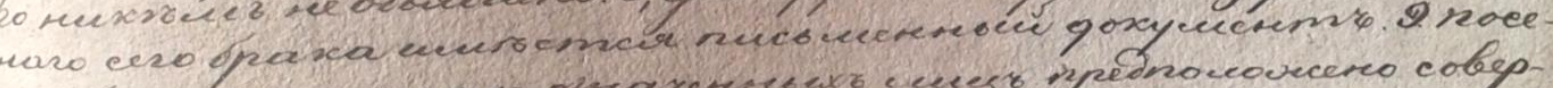

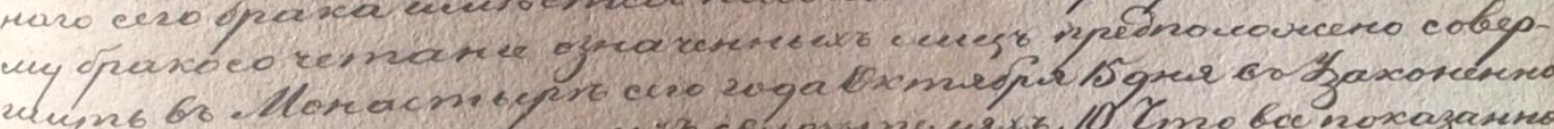

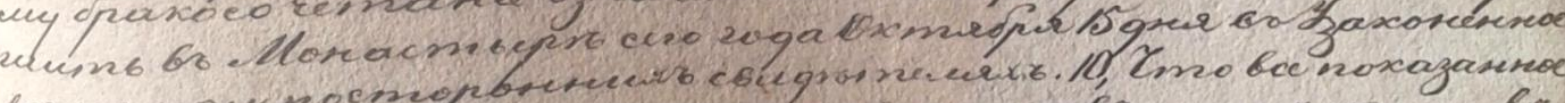

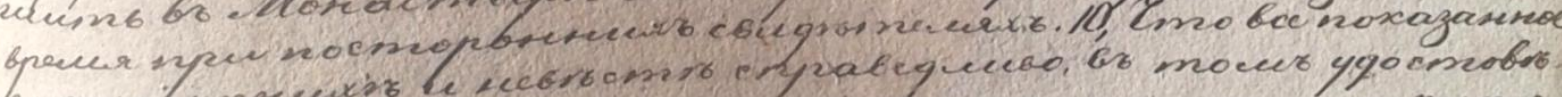

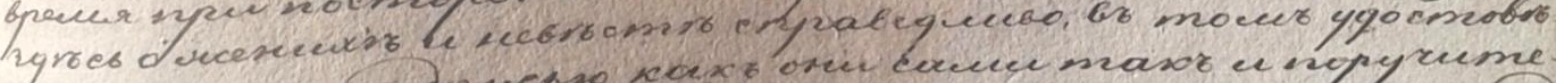

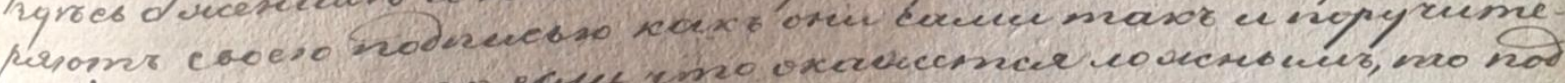

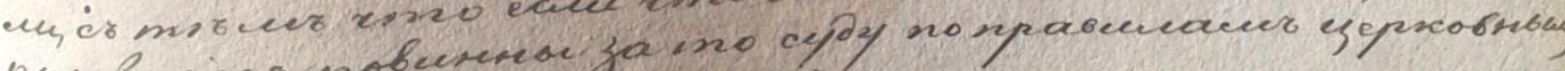
nucabuciear soburere jaingencer.

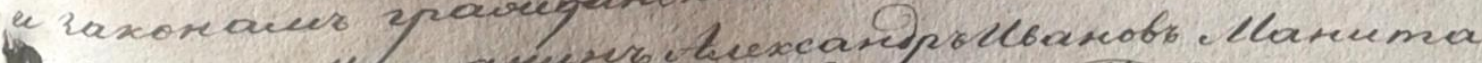

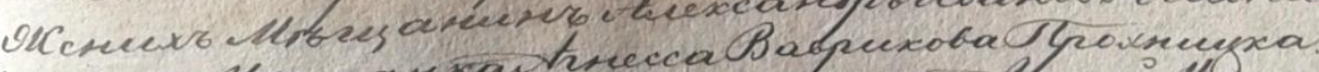

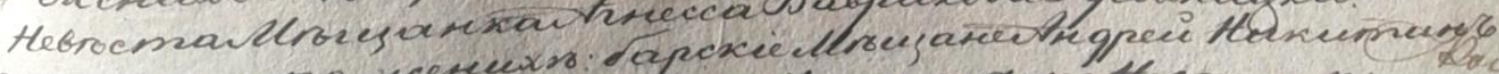

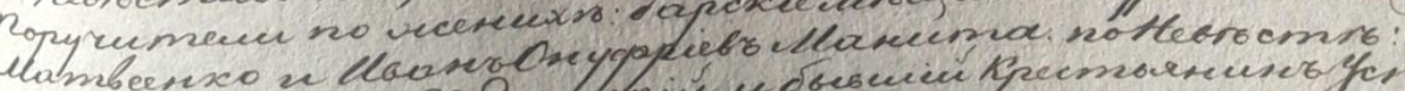

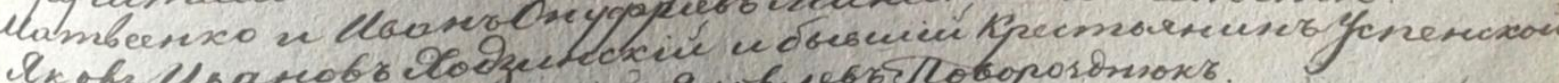

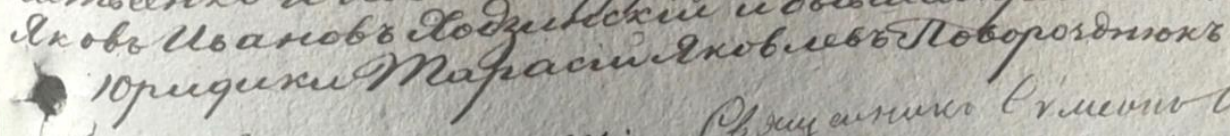


Додаток В. Відомості про віковий, соціальний, релігійний стан наречених за 1839-1855 рр. за даними метричної книги Свято-Успенської церкви м. Бар

\begin{tabular}{|c|c|c|c|c|c|c|}
\hline $\begin{array}{c}\text { № } \\
\Pi / \Pi\end{array}$ & $\begin{array}{c}\text { Ім'я, по } \\
\text { батькові, } \\
\text { прізвище }\end{array}$ & $\begin{array}{c}\text { Кіл- } \\
\text { ть } \\
\text { років }\end{array}$ & $\begin{array}{l}\text { Віроспо- } \\
\text { відування }\end{array}$ & $\begin{array}{c}\text { Соціальний } \\
\text { стан }\end{array}$ & $\begin{array}{c}\text { Місце } \\
\text { проживання }\end{array}$ & $\begin{array}{c}\text { Дата } \\
\text { вінчання }\end{array}$ \\
\hline 1 & 2 & 3 & 4 & 5 & 6 & 7 \\
\hline 1 & $\begin{array}{l}\text { Прокіп } \\
\text { Іванович } \\
\text { Поветчук } \\
\text { Агафія } \\
\text { Степанівна } \\
\text { Нечапка }\end{array}$ & 40 & $\begin{array}{l}\text { Православний } \\
\text { Православна }\end{array}$ & Селянин & $\begin{array}{l}\text { С.Войнашівка } \\
\text { С.Войнашівка }\end{array}$ & $\begin{array}{l}8.01 . \\
1839 p .\end{array}$ \\
\hline 2 & $\begin{array}{l}\text { Петро } \\
\text { Васильович } \\
\text { Вербицький } \\
\text { Олена Іванівна } \\
\text { Кульчицька }\end{array}$ & 25 & Православний & Громадянин & $\begin{array}{l}\text { М. Бар } \\
\text { М. Бар }\end{array}$ & $\begin{array}{l}15.01 . \\
1839 \mathrm{p} .\end{array}$ \\
\hline 3 & $\begin{array}{l}\text { Данило } \\
\text { Григорович } \\
\text { Чинкалюк } \\
\text { Фросина } \\
\text { Іванівна } \\
\text { Попик }\end{array}$ & 17 & Православний & Селянин & С. Шпирки & $\begin{array}{l}22.01 . \\
1839 \mathrm{p} .\end{array}$ \\
\hline 4 & $\begin{array}{l}\text { Мартин } \\
\text { Миколайович } \\
\text { Митковський } \\
\text { Марія } \\
\text { Федорівна } \\
\text { Ткачук }\end{array}$ & 20 & $\begin{array}{l}\text { Православний } \\
\text { Православна }\end{array}$ & Селянин & $\begin{array}{l}\text { С.Войнашівка } \\
\text { С.Войнашівка }\end{array}$ & $\begin{array}{l}22.01 . \\
1839 \mathrm{p} .\end{array}$ \\
\hline 5 & $\begin{array}{l}\text { Дмитро } \\
\text { Іванович } \\
\text { Ришовський } \\
\text { Параска } \\
\text { Олексіївна } \\
\text { Бєлоусова } \\
\end{array}$ & 19 & Православна & Міщанин & М. Бар & $\begin{array}{l}22.01 . \\
1839 \text { p. }\end{array}$ \\
\hline 6 & $\begin{array}{l}\text { Федір } \\
\text { Максимович } \\
\text { Маніта } \\
\text { Євдокія } \\
\text { Іванівна } \\
\text { Поворознюк }\end{array}$ & 20 & Православна & Міщанка & М. Бар & $\begin{array}{l}22.01 . \\
1839 \mathrm{p} .\end{array}$ \\
\hline 7 & $\begin{array}{l}\text { Кирило Ілліч } \\
\text { Лисицький } \\
\text { Анна Яківна } \\
\text { Назаревичева }\end{array}$ & 24 & $\begin{array}{l}\text { Православний } \\
\text { Православна }\end{array}$ & Оберофіцер & $\begin{array}{l}\text { М. Бар } \\
\text { М. Бар }\end{array}$ & $\begin{array}{l}22.01 . \\
1839 \mathrm{p}\end{array}$ \\
\hline
\end{tabular}




\begin{tabular}{|c|c|c|c|c|c|c|}
\hline 1 & 2 & 3 & 4 & 5 & 6 & 7 \\
\hline 8 & $\begin{array}{l}\text { Іван } \\
\text { Федорович } \\
\text { Поветчук } \\
\text { Євдокія } \\
\text { Михайлівна } \\
\text { Василевська }\end{array}$ & 22 & $\begin{array}{l}\text { Православний } \\
\text { Православна }\end{array}$ & Селянин & $\begin{array}{l}\text { М. Бар } \\
\text { М. Бар }\end{array}$ & $\begin{array}{l}29.01 \\
1839 \text { p }\end{array}$ \\
\hline 9 & $\begin{array}{l}\text { Петро } \\
\text { Вікентійович } \\
\text { Остапчук } \\
\text { Олена Іванівна } \\
\text { Франкова }\end{array}$ & 20 & $\begin{array}{c}\text { Православний } \\
\text { Православна }\end{array}$ & Селянин & $\begin{array}{l}\text { M. Бар } \\
\text { М. Бар }\end{array}$ & $\begin{array}{l}23.04 \\
1839 p\end{array}$ \\
\hline 10 & $\begin{array}{l}\text { Тимофій } \\
\text { Семенович } \\
\text { Глинник } \\
\text { Агафія } \\
\text { Павлівна } \\
\text { Мацюк }\end{array}$ & 45 & $\begin{array}{l}\text { Православний } \\
\text { Православна }\end{array}$ & $\begin{array}{l}\text { Рядовий } \\
\text { Уланського } \\
\text { полку } \\
\\
\text { Міщанка }\end{array}$ & $\begin{array}{l}\text { М. Бар } \\
\text { М. Бар }\end{array}$ & $\begin{array}{l}23.04 \\
1839 \text { p. }\end{array}$ \\
\hline 11 & $\begin{array}{l}\text { Яків } \\
\text { Андрійович } \\
\text { Юзвенко } \\
\text { Марія Іванівна } \\
\text { Енецька }\end{array}$ & 35 & $\begin{array}{l}\text { Православний } \\
\text { Римо- } \\
\text { католичка }\end{array}$ & Селянка & С. Ястрибці & $\begin{array}{l}25.05 . \\
1839 \text { p. }\end{array}$ \\
\hline 12 & $\begin{array}{l}\text { Іван } \\
\text { Миколайович } \\
\text { Папроцький } \\
\text { Анастасія } \\
\text { Романівна } \\
\text { Білоусова }\end{array}$ & 25 & $\begin{array}{c}\text { Римо-католик } \\
\text { Православна }\end{array}$ & Міщанка & $\begin{array}{c}\text { С.Вербівці } \\
\text { Ушицького } \\
\text { повіту } \\
\\
\text { М. Бар. }\end{array}$ & $\begin{array}{l}02.06 . \\
1839 \text { p. }\end{array}$ \\
\hline 13 & $\begin{array}{l}\text { Андрій } \\
\text { Михайлович } \\
\text { Бортник } \\
\text { Докія } \\
\text { Тимофіївна } \\
\text { Гримаченко }\end{array}$ & 25 & Римо-католик & Міщанин & $\begin{array}{l}\text { M. Бар } \\
\text { М. Бар }\end{array}$ & $\begin{array}{l}23.10 . \\
1840 \text { p. }\end{array}$ \\
\hline 14 & $\begin{array}{l}\text { Вікентій } \\
\text { Полікарпович } \\
\text { Нетупський } \\
\text { Марина } \\
\text { Олександрівна } \\
\text { Мошинська }\end{array}$ & 48 & $\begin{array}{l}\text { Православний } \\
\text { Православна }\end{array}$ & Громадянин & $\begin{array}{l}\text { M.Бар } \\
\text { М.Бар }\end{array}$ & $\begin{array}{l}21.08 . \\
1855 \text { p. }\end{array}$ \\
\hline
\end{tabular}


Додаток Г. Список поручителів та їх соціальний стан (складено О. Бакальцем за матеріалами метричної книги)

\begin{tabular}{|c|c|c|}
\hline № п/ா & Ім'я, по батькові, прізвище & Соціальний стан \\
\hline 1 & 2 & 3 \\
\hline 1 & Андрій Шаповальчук & селянин \\
\hline 2 & Лаврін Сарачук & селянин \\
\hline 3 & Павло Балагура & селянин \\
\hline 4 & Василь Вербицький & громадянин \\
\hline 5 & Іван Степанович Кульчицький & дворянин \\
\hline 6 & Данило Чипкалюк & селянин \\
\hline 7 & Фросина Попик & селянка \\
\hline 8 & Петро Чипкалюк & селянин \\
\hline 9 & Данило Гвоздецький & селянин \\
\hline 10 & Мартин Митковський & селянин \\
\hline 11 & Марта Ткачук & селянка \\
\hline 12 & Петро Захарчук & селянин \\
\hline 13 & Дмитро Ратибський & міщанин \\
\hline 14 & Параска Білоус & міщанка \\
\hline 15 & Олексій Микитович Гуд & міщанин \\
\hline 16 & Петро Васильович Верджбіцький & громадянин \\
\hline 17 & Семен Іванович Повієнчук & селянин \\
\hline 18 & Орест Грещинський & дворянин \\
\hline 19 & Яків Іванович Ходзінський & міщанин \\
\hline 20 & Павло Блащук & селянин \\
\hline 21 & Іван Підвальський & селянин \\
\hline 22 & Іван Федорович Гвоздецький & міщанин \\
\hline 23 & Роза Валанрук & селянка \\
\hline 24 & Устим Кремінський & міщанин \\
\hline 25 & Данило Криворучко & міщанин \\
\hline 26 & Микита Черниш & міщанин \\
\hline 27 & Анастасія Слободянючка & селянка \\
\hline 28 & Іван Дмитрович Висюк & селянин \\
\hline 29 & Іван Ткач & селянин \\
\hline 30 & Іван Боршанович & міщанин \\
\hline 31 & Данило Криворучко & міщанин \\
\hline 32 & Степан Барчук & селянин \\
\hline 33 & Василь Жаврук & міщанин \\
\hline 34 & Василь Іванович Корбут & дворянин \\
\hline
\end{tabular}




\begin{tabular}{|c|c|c|}
\hline 1 & 2 & 3 \\
\hline 35 & Степанида Балагура & селянка \\
\hline 36 & Іван Тихолаз & селянин \\
\hline 37 & Антон Мошинський & міщанин \\
\hline 38 & Яків Іванович Височанський & селянин \\
\hline 39 & Тимофій Войтков & селянин \\
\hline 40 & Ілля Захарчук & селянин \\
\hline 41 & Гнат Ткач & селянин \\
\hline 42 & Марчук & селянин \\
\hline 43 & Матрона Захарчук & селянка \\
\hline 44 & Іван Максімов & офіцер \\
\hline 45 & Ігнатій Зіжукало & дворянин \\
\hline 46 & Іван Царенко & міщанин \\
\hline 47 & Степан Максимович Якубчик & міщанин \\
\hline 48 & Дементій Іванович Надич & селянин \\
\hline 49 & Олексій Іванович Твардовський & селянин \\
\hline 50 & Антон Якович Сіпацький & Дворянин \\
\hline 51 & Свстарх Валентинович Масєркін & дворянин \\
\hline 52 & Василь Григорович Волощук & Дворянин \\
\hline 53 & Тарас Якович Поворознюк & селянин \\
\hline 54 & Онуфрій Іванович Маніта & міщанин \\
\hline 55 & Ілля Семенович Любчик & міщанин \\
\hline 56. & Іван Іванович Блажевський & міщанин \\
\hline 57. & Федір Андрійович Глінський & селянин \\
\hline 58 & Степан Степанович Кашубейко & селянин \\
\hline 59 & Андрій Матвійович Шаповальчук & селянин \\
\hline 60 & Семен Іванович Повітчук & селянин \\
\hline 61 & Іван Федорович Повітчук & - \\
\hline 62 & Федір Андрійович Гринник & - \\
\hline 63 & Андрій Федорович Бронецький & міщанин \\
\hline 64 & Олексій Петрович Юзвенко & міщанин \\
\hline 65 & Герасим Петрович Мацюк & міщанин \\
\hline 66 & Павло Карпович Трачевський & міщанин \\
\hline 67 & Микита Іванович Сторожук & міщанин \\
\hline 68 & Лев Іванович Петров & міщанин \\
\hline 69 & Василь Павлович Качановський & міщанин \\
\hline 70 & Федір Васильович Вороновський & міщанин \\
\hline 71 & Семен Васильович Яблоцький & унтер-офіцер \\
\hline
\end{tabular}




\begin{tabular}{|c|c|c|}
\hline $\mathbf{1}$ & $\mathbf{2}$ & $\mathbf{3}$ \\
\hline 72 & Алексій Федотів & фельдфебель \\
\hline 73 & Орест Лукич Матковський & - \\
\hline 74 & Микола Степанович Перковський & дворянин \\
\hline 75 & Назарій Добранський & дворянин \\
\hline 76 & Костянтин Іванович Войтович & міщанин \\
\hline 77 & Свирид Михайлович Василевський & міщанин \\
\hline 78 & Іван Онуфрійович Маніта & міщанин \\
\hline 79 & Іван Миколайович Мірчук & селянин \\
\hline 80 & Олександр Блажеєв-Мошинський & міщанин \\
\hline 81 & Олімпія Кривіцька & міщанка \\
\hline 82 & Павло Йосипович Хмелівський & міщанин \\
\hline 83 & Пилип Гаврилович Томашевський & міщанин \\
\hline 84 & Андрій Іванович Маковський & дворянин \\
\hline 85 & Микола Андрійович Пірнаковський & дворянин \\
\hline 86 & Іван Миколайович Гинкалюк & селянин \\
\hline 87 & Семен Григорович Демчук & селянин \\
\hline 88 & Кіндрат Кащенко & міщанин \\
\hline 89 & Ілля Степанович Любчак & міщанин \\
\hline 90 & Петро Семенович Третяк & міщанин \\
\hline
\end{tabular}

\section{ЛІТЕРАТУРА}

1. Бакалець О. А. Історія Украӥни з найдавніших часів до початку XXI ст. Навчальний посібник. / О. А. Бакалець. - Львів: Магнолія, 2016.

2.Грушевський М. С. Барське староство. Історичні нариси XV - XVIII ст. / М. С. Грушевський. - Львів, 1996.

3. Енциклопедія історії України: в 10-ти т. / Редкол.: В. А. Смолій (голова). - Т.6. К.: Наукова думка, 2009.

4. Єсюнін С. М. Міста Поділля у другій половині XIX - на початку XX ст.: монографія / С. М. Єсенін. - Хмельницький: ФОП Мельник А. А., 2015.

5. Калакура Я., Войцехівська І. Істричне джерелознавство. / Я. Калакура, I. Войцехівська. - К., 2006.

6. Легун Ю. В. Генеалогія селян Подільської губернії: джерела. / Ю. В. Легун. Вінниця, 2005.

7. Метрична книга Свято-Успенської церкви м. Бара. - Бар. -1839-1855. - 148 арк.

8. Мордвінцев В. М., Томазов В. В. Метричні книги. // Українська архівна енциклопедія. - К., 2008.

9. Мордвінцев В. М. Метричні книги. // Вісник Київського університету: Історія, вип. 41. - К., 1999. 
10. Томазов В. В. Генеалогія козацько-старшинських родів: історіографія і джерела (друга половина XVII - початок XXI ст.). / В. В. Томазов. - К., 2006.

PhD Alexey Bakalets (Bar, Ukraine)

THE METRIC BOOK OF THE HOLY-USPENSKY CHURCH FOR 1839-1855. AS A SOURCE FOR THE STUDY OF THE CIVIL STATUS OF THE RESIDENTS OF THE BAR REGION

The author of the article attempted to analyze the metric book of the Holy Dormition Orthodox Church of the city of Bar for the period from 1839 to 1855, revealing the peculiarities of the social status and religious affiliation of young residents of Bar and its environs.

Key words: Metric, Metric book, Acts of Civil Status, Brides.

доц. Алексей Бакалец (Бар, Украина)

МЕТРИЧЕСКАЯ КНИГА СВЯТО-УСПЕНСКОЙ ЦЕРКВИ ЗА 1839-1855 ГГ. КАК ИСТОЧНИК ПО ИССЛЕДОВАНИЮ ГРАЖДАНСКОГО СОСТОЯНИЯ ЖИТЕЛЕЙ БАРСКОГО РЕГИОНА

Автор статьи попытался проанализировать метрическую книгу Свято-Успенской православной церкви города Бар за период с 1839 по 1855 гг., раскрывая особенности социального положения и религиозной принадлежности молодых жителей Бара и его окрестностей.

Ключевые слова: метрика, метрическая книга, акты гражданского состояния, невесты.

доц. Олексій Бакалець (Бар, Україна)

МЕТРИЧНА КНИГА СВЯТО-УСПЕНСЬКОЇ ЦЕРКВИ ЗА 1839-1855 pp. ЯК ДЖЕРЕЛО ДОСЛІДЖЕННЯ ГРОМАДЯНСЬКОГО СТАНУ ЛЮДИНИ В БАРСЬКОМУ РЕГІОНІ У 30-50-х РОКАХ ХІХ СТОЛІТТЯ

Автор статті зробив спробу прочитати та проаналізувати метричну книгу СвятоУспенської православної церкви за період з 1839 до 1855 року, що розкриває особливості соціального стану та релігійної приналежності молодих жителів м. Бара та його околиць.

Ключові слова: метрика, метрична книга, акти громадянського стану, наречені.

* Бакалець Олексій Андрійович, кандидат історичних наук, доцент кафедри історії, правознавства та методики навчання Глухівського національного педагогічного університету імені Олександра Довженка, здобувач Інституту історії НАН України, член НСКУ. E-mail: bakalec_alex@ukr.net. 
DOI 10.38129/ Ann.Yur.Ist.2019.3.1.2.24

УДК 340.115 .3

\title{
НАРИС ТЕОРІЇ ПОДАТКОВОЇ ПОВЕДІНКИ
}

\author{
ОЛЕКСАНДР БЕЛОВ (Вінниця, Україна)*
}

Податкова теорія походження держави набирає все більше прихильників серед істориків юриспруденції. Однак, тлумачення та дефініція оподаткування вимагає не лише хорошої юридичної підготовки, але й застосування принципів так званого «соціально-психологічного підходу». Ось чому, говорячи і пишучи про податки, не можна оминати дослідницькою увагою психоісторичний контекст податкової поведінки.

Чому одні люди сплачують податки сумлінно і без незадоволення, а інші шукають способів уникнення навіть незначних відрахувань? Що змушує людей вигадувати найскладніші схеми уникнення сплати податків, ризикуючи великими штрафами і навіть свободою? Чому в деяких країнах ухиляння від сплати податків стає мало не загальнонаціональною характеристикою, а в інших є винятково рідкісним явищем? Відповіді на ці питання доволі часто криються в особливостях індивідуальної та групової психології. Прагнення з'ясувати причини тих чи інших дій суб'єкта і компанії по відношенню до сплати податків, і знайти способи керувати цими діями зумовило зростання уваги вчених-економістів і психологів до особливостей податкової поведінки.

Податкова поведінка є предметом вивчення податкової психології нового i перспективного розділу економічної психології, інтердисциплінарної науки на перетині економіки та психології, що надзвичайно активно й динамічно розвивається останніми десятиліттями.

Метою податкової психології є пояснення і розуміння 3 позицій індивідуальної та групової психології різних моделей поведінки платників податків, що можуть бути як економічно конструктивними (свідома, добровільна, повна сплата податків), так і деструктивними (різноманітні моделі ухиляння від сплати податків та податкового обману), а також розробка таких податкових моделей, що сприяли б формуванню та реалізації найбільш ефективних форм податкової поведінки.

Під податковою поведінкою ми розуміємо сукупність психологічних реакцій, пов'язаних із функиіонуванням суб'єкта в якості платника податків. 
Виділяють індивідуальну (personal tax behavior) i корпоративну (corporate tax behavior) поведінку. Перша розглядає особливості поведінки окремих суб'єктів у податковому процесі, друга - особливості стратегій підприємств, компаній, фірм, пов' язаних зі сплатою податків.

Податкова поведінка передбачає адаптацію індивіда в соціальному та економічному середовищі, пошук шляхів досягнення власних цілей, а також трансформацію суспільства та економіки через реалізацію різних податкових поведінкових моделей.

Фіскальні відносини - взаємодія платників податків та державних структур і посадових осіб, що адмініструють справляння податків передбачає формування свідомого ставлення суб'єкта до власне ідеї сплати податків, до конкретних податків і зборів, які він має сплатити, до податкової адміністрації взагалі, і до ії конкретної посадової особи, з якою платнику податків доводиться мати справу. У цьому контексті надзвичайно важливим $\epsilon$ аналіз і керування усіма ланками фіскальних відносин: продумана державна податкова та інформаційна політика, спрямована на роз'яснення суті податків, їх необхідності для існування держави, формування свідомого позитивного ставлення до сплати податків, роз'яснення економічного змісту і доцільності податків, що має сплатити особа, високий професійний рівень посадових осіб податкових органів (у тому числі, й навчання засадам спілкування, формування комунікативних навичок, запобігання конфліктам тощо).

3 психологічної точки зору податкова поведінка - вельми широке поняття. Податкова поведінка включає когнітивні, емоційні і поведінкові реакції індивіда, пов'язані з виконанням ним ролі суб'єкту податкової системи.

Когнітивний компонент податкової поведінки включає усвідомлення індивідом своєї ролі платника податків, формування ставлення до неї, раціоналізацію, аналіз відповідної інформації та прийняття рішень щодо обрання тієї чи іншої моделі податкової поведінки.

Можливість та об'єм усвідомлення людиною своєї соціальної ролі суб'єкта податкового процесу тісно пов'язані із загальним рівнем іï інтелекту, освіти, а також ступенем обізнаності у податкових питаннях. Така обізнаність визначається як доступністю необхідної інформації, так і власною активністю індивіда у цілеспрямованому пошуку інформації.

При прийнятті рішень щодо вибору суб'єктом тієї чи іншої моделі податкової поведінки важливу роль відіграють його моральні установки, особливості системи цінностей, а також домінуючі в даному суспільстві моделі поведінкової системи. 
Мотивациія до сплати податкіЪ - психологічне спонукання до певних дій зі сплати або несплати податків - може бути позитивною або негативною. Позитивна мотивація сплати податків (мотивація прагнення) це бажання відчути позитивні емоції - гордість, спокій, відчуття захисту і т.п., пов'язані із сумлінним виконанням податкових обов'язків, або ж бажання отримати ті чи інші пільги за своєчасну сплату податків. Позитивна мотивація несплати податків - зазвичай прагнення отримати матеріальну вигоду внаслідок «економії» недоплачених державі коштів. В основі негативної мотивації (мотивація уникнення) зазвичай лежить страх страх відповідальності, покарання, суспільного осуду, втрати репутації. Негативна мотивація спонукає суб'єкта сплачувати податки, щоб уникнути негативних наслідків - кримінальної або цивільної відповідальності, суспільного осуду, втрати репутації тощо. Негативна мотивація несплати податків - результат переважно деформованих суспільних уявлень; вона притаманна суспільствам, де панує нігілістичне, зневажливе ставлення до податків (що зазвичай поєднується зі зневажливим ставленням до держави); коли добровільна й свідома сплата податків розглядається як ознака простакуватості, недолугості, а ухилянням від сплати податків хизуються і виставляють як доблесть. Формування такої групової ідентичності у різних категорій населення, що протиставляється інтересам держави, формує передумови масового ухиляння від сплати податків.

Т. В. Меркулова пропонує класифікувати податкову поведінку в залежності від мотивації; при цьому платників податків поділяють на дві великі групи: опортуністів та законослухняних. До опортуністів належать особи, що у податковій звітності навмисно надають викривлені або неповні дані, приховують фактичні обсяги виробництва i доходів, свідомо обманюють податкові органи та інших учасників податкових відносин; деякі опортуністи переконані, що податки можна взагалі не платити. Законослухняними вважаються такі платники податків, що діють лише в рамках правил, завідомо не порушуючи законодавство [1]. Розвиваючи цей підхід, автор виділяє чотири типи податкової поведінки відповідно до співвідношення форми раціональності та ступеню егоїстичності у дотриманні власних інтересів: опортуніст-максимізатор (податкова поведінка спрямована на мінімізацію витрат, пов'язаних зі сплатою податків, при цьому припустимими способами досягнення цієї мети вважаються усі можливі, включаючи порушення формальних i неформальних норм оподаткування), опортуніст 3 обмеженою формою раціональності (суб'єкт прагне мінімальних податкових витрат, але обирає певну компромісну суму податків), законослухняний платник податків 
(йому притаманні нормативні варіанти поведінки, що відрізняються формою раціональності, при цьому платник податків розглядає варіанти мінімізації податків лише в рамках правил, і спеціально їх не порушує), та законослухняний платник податків 3 обмеженою формою раціональності (суб'єкт діє лише в рамках законних правил, але не прагне досягти мінімізації податкових витрат, а орієнтується на певну достатню величину) $[2]$.

V. Braithwaite, досліджуючи особливості мотивації в контексті податкової поведінки, виділив мотиваційні позиції (мотиви), які є взаємопов' язаними віруваннями, оцінками, очікуваннями та ставленнями, i визначають поведінку платників податків. Мотиваційні позиції відбивають соціальну відстань між платником податків та податковими органами, i зумовлюють особливості їх взаємодії. Виділяють п'ять мотиваційних позицій: зобов'язання, капітуляція, опір, уникання та гра. Обов'язковий платник вірить у переваги податкової системи та має морально правильні погляди; платник-капітулянт звертається до податкових органів, що мають високий авторитет; стійкий платник сумнівається у намірах податкових органів і намагається перевіряти їх; платник, що уникає, повністю дистанціюється від сплати; платник-гравець намагається скористатися прогалинами у податковому законодавстві. 3 урахуванням індивідуальної мотивації платників податків, податкові органи повинні обирати диференційований підхід з використанням примусових та регуляторних стратегій $[3,4]$.

Емоційна складова податкової поведінки включає різноманітні емоційні реакції, пов'язані із виконанням індивідом ролі суб'єкту податкового процесу, негативні: роздратування, невдоволення, агресія, злість, фрустрація; позитивні: гордість, задоволення; нейтральні (байдужість). Ці емоційні реакції можуть бути короткочасними - роздратування, злість і агресія як реакція на введення нового податку; довготривалими - знижений настрій внаслідок постійного усвідомлення важкого податкового тягаря і значною мірою визначати загальну податкову поведінку. Так, обгрунтовуючи рішення щодо припинення підприємницької діяльності під тиском податків, підприємці часто кажуть «втомився», «набридло», «задовбало», тобто, оперують психологічними, а не економічними термінами.

B. Maciejovsky, H. Schwarzenberger \& E. Kirchler вивчали вплив емоційних реакцій на податкову етику в рамках подвійної системної теорії афективних та когнітивних процесів [5]. Було виявлено, що загроза перевірок та штрафів ефективна лише тоді, коли люди здатні до 
раціональної обробки інформації, а у дослідженні G. Coricelli et al. підтверджено, що високий рівень емоцій корелює 3 низькою податковою дисципліною [6].

Поведінковий компонент включає свідому активність суб'єкта 3 реєстрації в якості платника податків, заповнення податкових декларацій, сплату податків, їх повернення, контролю податків тощо. Поведінковий компонент тісно пов'язаний 3 когнітивним, мотиваційним, емоційним компонентами.

Сплата податків може здійснюватися добровільно, під впливом усвідомлення громадянином необхідності підтримання держави податками як власного громадянського обов' язку (так званий «податок Кларка»), або ж під дією примусу держави - як обмін сплати громадянином обов'язкових платежів на суспільні блага; при цьому держава може ігнорувати ставлення до цього платників податків (так званий «податок Піга») [7].

Історично першим з'являється податок Піга. У перших суспільствах роль податків виконувала данина, що розглядалася як плата переможеного переможцю, слабого - сильному; така данина була, по суті, платою за право на існування. 3 розвитком держави та суспільної свідомості відбувається трансформація ставлення платників податку від примусового обов' язкового платежу до усвідомленої необхідності забезпечення функціонування держави шляхом добровільної і своєчасної сплати податків.

Першим дослідженням податкової поведінки з економічних позицій вважаються дослідження M. G. Allingham \& A. Sandmo [8], що є продовженням парадигми економічної злочинності G. S. Becker [9]. Платник податків у цій моделі поставлений у позицію гравця, що грає 3 податковим органом, і змушений обирати між дотриманням податкових зобов'язань і ризиковою перспективою ухилення від податків, тобто між правовою та кримінальною поведінкою. Основними чинниками, які визначають вибір тієї чи іншої моделі поведінки, є співвідношення ставки податку, ймовірність викриття і розмір покарання (штрафу) за податкові порушення. Вважається, що головним фактором, що змушує людину сплачувати податки є страх викриття і покарання (парадигма економічного стримування).

Водночас, ця модель піддається критиці. Так, дослідження J. Slemrod, M. Blumenthal \& C. Christian засвідчили, що стратегія погроз ефективна лише по відношенню до платників 3 малим і середнім доходом, натомість великі платники податків під впливом погроз схильні занижувати фактичні обсяги обігу [10].

H. J. Kleven et al. довели, що загрози аудиту мали значний вплив на 
об'єктивне представлення доходів, про які платники звітували самостійно, i не впливали на звітність третіх сторін.

Психологи наголошують, що неокласичні моделі не враховують суто людські, психологічні фактори [11]. У цих моделях платники податків розглядаються як абсолютно раціональні, егоїстичні та ізольовані у прийнятті рішень; вони мотивовані лише на максимальне збільшення очікуваної користі фінансових результатів [12].

На противагу економічним, запропоновані психологічні моделі податкової поведінки, що зосереджуються на когнітивних та контекстних аспектах процесу прийняття рішення платниками податків. J. Olsen, M. Kang \& E. Kirchler звертають увагу на низьку економічну обізнаність платників податків, які не спроможні обчислити оптимальний обсяг приховуваного доходу; маючи обмежені пізнавальні можливості, вони чутливі до способів, якими проблема «формується», i їх судження та вибір часто відрізняються від тих, що описуються стандартною економічною моделлю [12]. На відміну від теорії очікуваної користі, теорія перспектив D. Kahneman \& A. Tversky постулює, що результати рішення індивідуума оцінюються змінами в доходах за певними орієнтирами, а не кінцевим станом його майна. Суб'єктивна цінність прибутку чи збитку визначається цільовою функцією, суттєвішою для втрат, ніж для прибутків; це означає, що суб'єктивна цінність даної втрати сприймається як більш негативна, ніж позитивний ефект приросту такого ж розміру - i, як наслідок, люди зазвичай намагаються уникнути збитків. Відповідно, в залежності від того, становить потенційний результат втрати або прибутки в актуальних сферах діяльності людини, визначається готовність приймати на себе ризики: люди більшою мірою схильні йти на ризик для уникнення втрат, ніж для одержання прибутку [13].

Важливим фактором прийняття платником податків рішення щодо вибору тієї чи іншої моделі податкової поведінки є особисті переконання і моральні норми. Люди з позитивними установками щодо податкової етики та високою моральністю не потребують примусових та репресивних заходів, тоді як по відношенню до людей зі слабкими моральними нормами та негативними установками ефективність примусових заходів є низькою $[14,15]$. M. Wenzel зазначає, що вплив соціальних норм на податкову поведінку опосередковується особистими нормами; останні $\epsilon$ інтернаціоналізованими соціальними нормами [16].

Паралельно 3 дослідженням особливостей індивідуальних психологічних реакцій, пов'язаних зі сплатою податків, ряд дослідників привертають увагу до соціально-психологічних факторів податкової 
поведінки. Податкова система базується на соціальній взаємодії суб'єктів, тож для неї актуальні такі поняття, як справедливість, мораль, знання, довіра, а також загальні закономірності міжіндивідуальної, індивідуальногрупової та міжгрупової взаємодії.

Справедливість є стрижневим поняттям у формуванні ставлення платників податків до податкової системи; саме справедливість найчастіше зазначали опитані при характеристиці свого відношення до податкової системи [17, 18]. M. Wenzel виділяє три основних складових конструкції концепції справедливості: розподільну, процедурну та справедливу справедливість. Справедливий розподіл означає справедливий обмін вигодами та витратами з урядом та справедливий розподіл податкового навантаження серед платників податків; процедурна справедливість передбачає справедливі процеси збору податків, такі як поважне поводження з платниками податків з боку податкових органів; нарешті, справедлива справедливість стосується обгрунтованості винагороди та покарання [19]. На думку J. Olsen, M. Kang \& E. Kirchler, збільшення справедливості може досягатися за рахунок зменшення соціальної відстані між платниками податків та податковими органами; при цьому санкції чи покарання здатні підірвати легітимність податкових органів, якщо вони сприймаються як несправедливі [12]. К. Murphy зазначає, що довіра до податкового органу та його процедур відіграє ключову роль у визначенні бажання платників податків дотримуватися правил та рішень влади [20]. Ще одним способом збільшення відчуття справедливості при сплаті податків є можливість для платника податків обирати, на які цілі будуть витрачатися їхні податки [21].

У ряді досліджень було виявлено суттєвий вплив соціальних установок i поведінки значущого оточення на податкову поведінку індивіда. Якщо у референтних групах або у значущих осіб переважають установки на ухиляння від податків, це зменшує у індивіда почуття провини за порушення податкового законодавства, і збільшує ймовірність податкових девіацій; оскільки особисті та соціальні норми є взаємозалежними, може бути доволі проблематично чітко відрізнити ці два ефекти $[12,22,23]$.

Суспільні установки відіграють провідну роль у формуванні мотивації позитивної податкової поведінки. У цьому зв'язку необхідно вивчати успішний досвід розвинених країн Західного світу щодо позитивної податкової поведінки і впроваджувати ті моделі, які засвідчили свою ефективність.

Таким чином, проблема вибору моделі податкової поведінки 
платником податків є однією з центральних проблем податкової психології, що знаходиться на перетині наукових і практичних інтересів економіки,

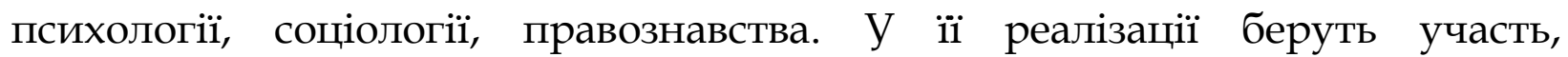
взаємодіючи і вступаючи в конфронтацію, психологічні механізми (когнітивно-мотиваційні, емоційні, поведінкові), а також соціальні, економічні та правові фактори. Комплексний аналіз цих механізмів відкриває шлях до розробки ефективних податкових моделей.

Класифікація податкової поведінки є одним 3 основних завдань податкової психології. Сьогодні запропоновано багато видів податкової поведінки: внутрішню і зовнішню, природну і надбану, умисну і неумисну, усвідомлену і неусвідомлену, правильну і хибну та ін. [24].

3 психологічної точки зору виділяють правильну, хибну, комфортну і нестандартну поведінку платників податків. Під правильною поведінкою розуміють адекватну поведінку, спрямовану на досягнення бажаної мети платника податків, під комфортною поведінкою - адекватну поведінку, спрямовану у бік від бажаної мети платника податків, нестандартна та помилкова поведінка належать до неадекватної поведінки залежно від мети платника податків; помилкова поведінка може бути пов'язана із випадковістю (неправильна оцінка ситуації, не зрозумів, відволікся), фізикальними проблемами (втома, погане самопочуття), некомпетентністю, відсутністю належних знань, вмінь і навичок, невихованістю і т. ін., морально-психологічного стану платників податків [24].

Фундаментальними поняттями податкової психології, поряд 3 податковою поведінкою, $є$ податковий менталітет, податкова мораль, податкова протидія, почуття податкового тягаря. Виділяють також асоційовані поняття: податкова культура, податкова грамотність та податкова дисципліна.

Податковий менталіmет - це сукупність психологічних установок індивіда по відношенню до оподаткування, складова загального національного менталітету.

Вельми важливими факторами податкової поведінки є соціальні норми: переконання, установки та моральність платників податків. Деякими авторами наголошується, що етичні установки та соціальна взаємодія відіграють провідну роль у розумінні причин ухилення від податків та податкової дисципліни [25].

Надзвичайно важливим для формування податкової поведінки є податковий клімат - відносини між податковими органами та платником податків. У цьому зв' язку V. Pukelienė \& A. Kažemekaitytė зазначають, що потужні податкові органи викликають у платників більшу довіру, що 
впливає на його готовність до співпраці. Водночас, це пов'язане 3 посиленням примусових заходів, які дозволяють посилити рівень дотримання податкових вимог, але загрожують знищити добровільне дотримання законів платниками податків [26].

На думку G. Lisi, загальне узгодження податкового законодавства та макроекономічного клімату більшою мірою посилюється заходами, що стимулюють довіру між податковими структурами і платниками податків, ніж примусовими заходами, оскільки це призводить до створення кооперативного суспільства та забезпечення легітимності владних структур; проте, й потужні примусові заходи не можна не брати до уваги, оскільки вони також призводять до встановлення довіри, зокрема через контроль нечесних платників податків та сприйняття справедливості в суспільстві чесними платниками податків [27]. На думку L. P. Feld \& B. S. Frey, прозорість та узгодженість процесуальних дій з боку податкових органів можуть сприяти підвищенню якості інституційної роботи, наслідком чого є позитивний ефект на рівні дотримання платниками вимог податкового законодавства [28].

Податкова мораль - це сукупність установок особистості по відношенню до податкового законодавства і податкової системи. Податкова моральність - сукупність особистих правил щодо податкових вимог, що можуть призвести до переживання почуття задоволення (щастя) в разі їх дотримання, і почуття провини, втрати репутації, сорому і т.п. в разі їх невиконання - важливий фактор формування податкової поведінки; водночас, високий рівень податкової моралі не означає автоматично високого рівня дотримання податкового законодавства, він лише відображає індивідуальні преференції, які можуть відрізнятися від реальної поведінки $[27,29,30]$.

У цьому контексті державі надзвичайно важливо забезпечити відчуття соціальної справедливості при визначенні податкової політики. Впевненість платника податків у справедливості і прогресивності суспільного ладу при розумінні обгрунтованості та необхідності існуючих податків зумовлює перспективу формування позитивної податкової поведінки, а несправедливість, соціальне розшарування, принцип «багатим - все, іншим - закон», безкарність породжує розчарування у суспільстві та його цінностях, правовий та податковий нігілізм, суспільну пасивність та спротив податковій політиці держави.

На особливості податкової поведінки справляє вплив соціальний статус платника податків. На думку Н. Гетьман та Ю. Литвинової, державні службовці орієнтуються на поняття соціальної справедливості; робітники 
сприймають податки як інструмент політиків, використання податків для фінансування бюджетного дефіциту викликає у них критику уряду; офісні працівники та інженерно-технічний персонал ставляться до податків як до інструменту, що забезпечує соціальну безпеку і добробут суспільства, а також як до неминучого зла, яке, крім усього, генерує особисті фінансові втрати [31].

Ставлення соціальної групи до питання виконання податкових обов'язків фіксується в ментальності громадян; концепція громадянського обов'язку передбачає, що індивіди мотивовані не лише зростанням власного добробуту, а у почуттям відповідальності перед суспільством і нацією; громадяни з високим рівнем почуття власного обов'язку обирають стратегію відповідального співробітництва навіть за можливості ухиляння, їх поведінка регулюється не зовнішніми перевірками чи санкціями, а внутрішніми переконаннями і турботою про суспільство [31]. Автори наголошують, що в умовах більш високої довіри громадянина до держави податкові збори набагато більші, ніж в умовах низької довіри, особливо за слабкої влади; в умовах низького рівня довіри високий рівень влади призводить до більшого стягнення податків, у цьому випадку мова йде про примусовість як основну мотивацію поведінки громадян (тобто, рівень добровільної чесності дуже малий); по мірі зростання довіри до податкових органів збільшується добровільне бажання співпрацювати з ними [31].

Відчутmя податкового тягаря - психологічні почуття, пов'язані 3 усвідомленням індивідом необхідності сплачувати податки. Найчастіше відчуття податкового тягаря асоціюється з негативними психоемоційними реакціями, пов'язаними 3 усвідомленням індивідом необхідності відчужувати частину власних благ на користь держави, та їх втрати.

Відчуття податкового тягаря надзвичайно посилюється за наявності у платника податків відчуття соціальної несправедливості, та переконання, що податок, накладений на нього, є непропорційно великим, або більшим по відношенню до інших соціальних верств.

Відчуття податкового тягаря тісно пов'язане 3 емоційним компонентом податкової поведінки. Високе відчуття податкового тягаря асоційоване з негативними емоціями роздратування, розчарування, суму, злості та ін.

Паралельно з відчуттям податкового тягаря у платника податків може виникати почуття непропорційно малого об'єму соціальних благ, що надаються йому державою. Виражене відчуття податкового тягаря тісно пов' язане з податковим спротивом.

Податкова протидія (податковий спротив) - сукупність психологічних 
та поведінкових реакцій по відношенню до податкового тягаря. Податкова протидія передбачає певні дії, до яких вдається платник податків для зменшення або уникнення податкового тягаря. Податкова протидія включає різні форми податкових девіацій.

Податкові девiauї справляють негативний вплив на відчуття соціальної справедливості в суспільстві, адже частина платників сплачує податки вчасно і в повному обсязі, а частина ухиляється від них.

Причинами податкових девіацій є недостатнє розуміння платниками економічної суті та необхідності податків, низький рівень податкової культури, правовий нігілізм, деформація соціальних та економічних відносин у суспільстві зі значною тінізацією економіки.

Податкові девіації можуть бути зумовлені корисливими мотивами, а також бути наслідком зневажливого ставлення до держави, ії цінностей, морально-етичних норм, власних обов' язків.

M. О. Акопджанова пропонує шукати зв'язок між податковими девіаціями та індивідуально-типологічними характеристиками девіантів. Вона пропонує наступну класифікацію порушників податкового законодавства: правопорушник шизоїдного типу особистості, який характеризується аутистичністю, багатством внутрішнього світу, переживаннями, надмірною чутливістю, схильністю до абстрагування, зазвичай обирає в якості способу уникнення оподаткування маніпулювання витратами; натомість, правопорушник астенічного типу особистості, який характеризується дратівливістю, захисними реакціями пасивного типу, реакціями уникнення, іпохондичністю, зазвичай обирає в якості способів ухиляння від оподаткування приховування виторгу або доходу шляхом невідображення їх у податкових деклараціях [32].

На думку Е. Дюркгейма, який вперше запропонував соціологічне пояснення природи девіацій, вони є результатом соціальної дезорганізації, що, у свою чергу, є наслідком втрати ідеалів, краху культурних цінностей і соціальних норм в часи криз і глибоких соціальних потрясінь. Деформація соціальних відносин активізує пріоритет індивідуальних інтересів над суспільними, що зумовлює трансформацію поведінки.

У цьому зв'язку необхідно зупинитися на ще одному фундаментальному понятті податкової психології - податковiū культурі.

Вперше термін «податкова культура» використав I. Шумпетер у своїй статті «Економія і соціологія податку на прибуток». За його визначенням, податкова культура є вираженням людської духовності i творчості, спрямовані на збільшення рівня податкової свідомості суспільства.

Сучасне визначення податкової культури охоплює не лише повноту і 
своєчасність сплати обов'язкових податкових платежів, а й характеризує певну соціальну зрілість суспільства, рівень податкової обізнаності та свідомості населення, стан розвитку підприємництва та загального соціально-економічного стану суспільства.

Податкова культура є елементом загальної економічної культури і суспільної свідомості учасників податкового процесу. У формуванні податкової культури беруть участь індивідуально-психологічні, особистісні, мотиваційні особливості, система переконань i установок індивіда, соціально-психологічні характеристики суспільства, загальний рівень економічної культури і суспільної свідомості, особливості правової атмосфери.

Становлення податкової культури суспільства відбувається через усвідомлення платниками податків необхідності їх сплати, розуміння неможливості реалізації державою своїх функцій 3 національної безпеки, оборони, охорони здоров'я, освіти, соціального забезпечення тощо.

С. А. Іванова зазначає, що механізм формування податкової культури структурно включає три взаємопов'язані підсистеми, що складають ії внутрішній зміст: механізм формування податкової культури платника податків, що забезпечує формування системи його потреб, ціннісних орієнтацій та очікувань, що $є$ найважливішим елементом інституціоналізації; механізм формування податкової культури податкових органів, що сприяє мобілізації податків і зборів; механізм формування податкової культури інших суб'єктів, які беруть участь у податковому процесі, забезпечує повне і своєчасне надходження сум податків і зборів в бюджет [33].

Водночас, механізм формування податкової культури являє собою діяльність фінансових інститутів 3 організації функціонування його складових структурних елементів (підсистем), тобто 3 організації податкового процесу у суворій відповідності до норм податкового права [34].

При цьому податкова культура - це відносно цілісна підсистема економічної та загальної культури людини, пов'язана з нею єдиними категоріями: культурою мислення, поведінки, спілкування та діяльності; вона розкриває приватний аспект буття людини у податковій сфері [35].

В. Ю. Кашаєва виділяє наступні проблеми, що заважають формуванню податкової культури: нестабільне законодавство; недостатня система інформування та консультування громадян; низький рівень якості виконання податкових процедур; недовіра 3 боку населення по відношенню до податкових органів; проблема взаємної соціальної 
відповідальності між суб'єктами податкових відносин; непрестижність праці у податкових органах, низька соціальна мотивація, велика плинність кадрів; процес глобалізації як причина росту конкуренції фірм та внаслідок цього - постійний пошук суб'єктами господарювання способів мінімізації податкових платежів [34].

На думку Д. О. Касімова, інструментарій формування податкової культури вельми широкий. До нього можна віднести систему податків та їх елементи, види та форми організації податкових відносин, податкову поведінку, податкову дисципліну, методи податкового планування, форми, види та способи податкових перевірок, види відповідальності, санкції, види інформаційних систем, податковий моніторинг, аудит та їх інструменти, системи оплати праці працівників податкових органів, показники оцінки результативності та ефективності податкових перевірок i рейтингові системи, показники і способи покращення обслуговування платників податків, мирові угоди між податковими органами та платниками податків та ін. Пріоритетними напрямками підвищення рівня податкової культури є вжиття заходів зі спрощення податкового законодавства і удосконалення механізму вирішення податкових спорів; суттєве підвищення ефективності взаємодії податкових органів і платників податків; підвищення рівня інформованості, розвиток податкового консультування громадян, рекламно-інформаційні заходи, використання засобів масової інформаціі; впровадження схем з покращення якості виконання податкових процедур; підвищення іміджу і престижу роботи у податкових органах [36].

Одним з найважливіших елементів податкової культури є податкова дисципліна. Зазвичай під податковою дисципліною розуміють своєчасну сплату фізичними та юридичними особами усіх визначених законодавством обов'язкових податків і зборів до бюджетів усіх рівнів. Однак, податкова дисципліна - це й систематичне навчання, розвиток i контроль моральних і фінансових спроможностей і можливостей платника податків розраховуватися з бюджетами 3 урахуванням різних ситуацій взаємодії податкових інспекцій 3 прийому та оформлення податків і податкових зобов'язань [33]. Податкова дисципліна підтримується за рахунок правових, адміністративних та морально-етичних факторів.

Податкова грамотність - це ступінь обізнаності населення у податковому законодавстві, та вміння застосовувати законодавчі норми у сфері оподаткування для забезпечення високого рівня податкової дисципліни, а також високої податкової культури в цілому.

Таким чином, податкова психологія - це новий, перспективний напрямок економічної психології, що динамічно розвивається останніми 
десятиліттями. Податкова психологія зачіпає важливі сфери економіки, психології, соціології, правознавства.

Податкова психологія вивчає податкову поведінку суб'єктів податкового процесу, їх взаємодію, а також розробляє заходи оптимізації дій повної та своєчасної сплати податків з позицій психологічної науки.

\section{ЛІТЕРАТУРА}

1. Меркулова Т. В. Институт налога / Т. В. Меркулова. - Харьков, 2006.

2. Меркулова Т. В. Налоговое поведение: институциональные аспекты анализа / Т. В. Меркулова // Научные труды ДонНТУ (Серия экономическая). 2005, Вып. 89(3). - С. 159-165.

3. Braithwaite V. Taxing democracy. Understanding tax avoidance and evasion / V. Braithwaite. - Aldershot: Ashgate Publishing Limited, 2003.

4. Braithwaite V. Defiance in taxation and governance: Resisting and dismissing authority in a democracy / V. Braithwaite. - Edward Elgar Publishing, 2009.

5. Maciejovsky B. Rationality versus emotions: The case of tax ethics and compliance / B. Maciejovsky, H. Schwarzenberger, E. Kirchler // Journal of Business Ethics. - 2012, Vol. 1. - P. 339-350.

6. Coricelli G. Cheating, emotions, and rationality: an experiment on tax evasion / G. Coricelli, M. Joffily, C. Montmarquette, M. C. Villeval // Experimental Economics. - 2010, Vol. 13. - P. 226-247.

7. Іванов Ю. Б. Податкова система: підручник / Іванов Ю. Б., Крисоватий А. І., Десятнюк О. М. - К.: Аттіка, 2006.

8. Allingham M. G. Income tax evasion: A theoretical analysis / M. G. Allingham, A. Sandmo // Journal of Public Economics. - 1972, Vol. 1. - P. 323-338.

9. Slemrod J. Taxpayer response to an increased probability of audit: evidence from a controlled experiment in Minnesota / J. Slemrod, M. Blumenthal, C. Christian // Journal of Public Economics. - 2001, Vol. 79. - P. 455-483.

10. Kleven H. J. Unwilling or unable to cheat? Evidence from a tax audit experiment in Denmark / H. J. Kleven, M. B. Knudsen, C. T. Kreiner, S. Pedersen, E. Saez / / Econometrica. 2011, Vol. 79. - P. 651-692.

11. Cullis J. G. Why people pay taxes: From a conventional economic model to a model of social convention / J. G. Cullis, A. Lewis // Journal of Economic Psychology. - 1997, Vol. 18. - P. 305-321.

12. Olsen J. Tax Psychology / J. Olsen, M. Kang, E. Kirchler. - Cambridge University Press, 2018. - P. 405-429.

13. Kahneman D. Prospect theory: An analysis of decision under risk. Econometrica / D. Kahneman, A. Tversky // Journal of the Econometric Society. 1979, Vol. 47. - P. 263-292.

14. Alm J. Do ethics matter? Tax compliance and morality/ J. Alm, B. Torgler // Journal of Business Ethics. - 2011, Vol. 101. - P. 635-651.

15. Wenzel M. The social side of sanctions: personal and social norms as 
moderators of deterrence. / M. Wenzel // Law and Human Behavior. - 2004, Vol. 28. P. 547-567.

16. Wenzel M. An analysis of norm processes in tax compliance / M. Wenzel / / Journal of Economic Psychology. - 2004, Vol. 25. - P. 213-228.

17. Braithwaite V. Taxing democracy. Understanding tax avoidance and evasion / V. Braithwaite. - Aldershot: Ashgate Publishing Limited, 2003.

18. Taylor N. Understanding taxpayer attitudes through understanding taxpayer identities: In V. Braithwaite (ed.), Taxing democracy. Understanding tax avoidance and evasion (pp. 71-92) / N. Taylor. - Aldershot: Ashgate Publishing Limited, 2003

19. Wenzel M. Tax compliance and the psychology of justice: Mapping the field: In V. Braithwaite (Ed.), Taxing Democracy. Understanding Tax Avoidance and Evasion (pp. 41-70) / M. Wenzel. - Aldershot: Ashgate Publishing Limited, 2003.

20. Murphy K. The role of trust in nurturing compliance: A study of accused tax avoiders / K. Murphy / / Law and Human Behavior. - 2004, Vol. 28. - P. 187-209.

21. Casal S. Tax compliance depends on voice of taxpayers / S. Casal, C. Kogler, L. Mittone, E. Kirchler // Journal of Economic Psychology. - 2016, Vol. 56. - P. 141-150.

22. Wartick M. The effects of observing a peer's likelihood of reporting income on tax reporting decisions / M. Wartick, T. Rupert // Advances in Taxation. 2010, Vol. 19. - P. 65-94.

23. Onu D. The role of social norms in tax compliance: theoretical overview and practical implications / D. Onu, L. Oats // Journal of Tax Administration. - 2015, Vol. 1. - P. 113-137.

24. Зима О. Г. Анализ видов и типов налогового поведения / О. Г. Зима // Науковий вісник Національного університету ДПС України (економіка, право). - 2013, № 1(60). - С. 74-79.

25. Alm J. Do Ethics Matter? Tax Compliance and Morality / J. Alm, B. Torgler / / . Journal of Business Ethics. - 2011, Vol. 101(4). - P. 635-651.

26. Pukelienè V. Tax behaviour: Assessment of Tax compliance in European Union countries / V. Pukelienè, A. Kažemekaitytė // Ekonomika. - 2016, Vol. 95(2). P. 30-56.

27. Lisi G. The interaction between trust and power: Effects on tax compliance and macroeconomic implications / G. Lisi // Journal of Behavioral and Experimental Economics. - 2014, Vol. (53). - P. 24-33.

28. Feld L. P. Trust breeds trust: How taxpayers are treated. / L. P. Feld, B. S. Frey / / Economics of Governance. - 2002, Vol. 3(2). - P. 87-99.

29. Casagrande A. The effect of competition on tax compliance: The role of audit rules and shame / A. Casagrande, D. D. Cagno, A. Pandimiglio, M. Spallone // Journal of Behavioral and Experimental Economics. - 2015, Vol. 59. - P. 96-110.

30. Christian R. C. Empathy, sympathy, and tax compliance / R. C. Christian, J. Alm / / Journal of Economic Psychology. - 2014, Vol. 40. - P. 62-82. 
31. Гетьман Н. Экспертный канал «Открытая экономика» [Электронный ресурс] / Н. Гетьман, Ю. Литвинова. - Режим доступа: http://www.opec.ru/1318632.html.

32. Акопджанова Л. О. Способы совершения налоговых преступлений и личность налогового преступника / Л. О. Акопджанова // Налоги. - 2011, № 2. C. 23-26.

33. Иванова С. А. Налоги и налогообложение / С. А. Иванова. - Москва: Юнити, 2011. - С.101-122.

34. Кашаева В. Ю. Налоговая культура Российской Федерации: понятие, проблемы и пути их решения [Электронный ресурс] / В. Ю. Кашаева. - Режим доступа: https://www.scienceforum.ru/2016/pdf/21574.pdf.

35. Гончаренко Л. И. О новой дисциплине: современные тенденции в формировании налоговой культуры / Л. И. Гончаренко, Н. И. Осетрова // Налоги и налогообложение. - 2011, № 11. - С. 55-78.

36. Касимов Д. О. Институциональные основы формирования и развития налоговой культуры: дисс... канд. экон. наук / Д. О. Касимов. - Саратов, 2012.

PhD Oleksandr Belov (Vinnitsya, Ukraine)

\section{THE THEORY OF TAX BEHAVIOR: INTRODUCTION}

The article provides a detailed description of existing theories of tax behavior. All available data on the history of tax behavior expressed through categories of tax morality, tax emotions, tax counteraction, tax deviations, tax mentality are summarized. The author insists on the necessity of full implementation of tax psychology independent science on the border of psychology and jurisprudence. Tax behavior is defined as a set of psychological reactions related to the functioning of the taxpayer. Socio-psychological, behaviorist and physiocratic approaches are synthesized regarding the definition of the concept of "tax behavior", and the hierarchy of psychological functions of tax behavior is investigated.

Keywords: Taxes, Finance, Tax Psychology, Tax Behavior, Tax Mentality, Tax Counteraction, Tax Deviations.

канд. мед. наук Александр Белов (Винница, Украина)

\section{ОЧЕРК ТЕОРИИ НАЛОГОВОГО ПОВЕДЕНИЯ}

Статья обобщает все имеющиеся данные по истории и теории налогового поведения. Автор определяет налоговое поведение как совокупность психологических реакций, связанных с функционированием объекта налогообложения. Синтезируются социально-психологический, бихевиористский и физиократический подходы к дефиниции понятия «налоговое поведение», исследуется иерархия психологических функций налогового поведения.

Ключевые слова: налоги, финансы, налоговая психология, налоговое поведение, налоговый менталитет, налогове противодействие, налоговые девиации. 
канд. мед. наук Олександр Белов (Вінниця, Україна)

\section{НАРИС ТЕОРІЇ ПОДАТКОВОЇ ПОВЕДІНКИ}

Стаття містить детальний опис існуючих теорій податкової поведінки. Узагальнюються всі наявні дані з приводу історії податкової поведінки, вираженої через категорії податкової моралі, податкових емоцій, податкової протидії, податкових девіацій, податкового менталітету. Автор наполягає на необхідності повноцінного впровадження податкової психології - самостійної науки на межі психології та юриспруденції. При цьому, податкова поведінка визначається як сукупність психологічних реакцій, пов'язаних із функціонування суб'єкта сплати податкових платежів. Синтезуються соціально-психологічний, біхевіористський і фізіократичний підходи 3 приводу дефініції поняття «податкова поведінка», досліджується ієрархія психологічних функцій податкової поведінки.

Ключові слова: податки, фінанси, податкова психологія, податкова поведінка, податковий менталітет, податкова протидія, податкові девіації.

* Белов Олександр Олександрович - кандидат медичних наук, лікар-психіатр, медичний психолог, асистент кафедри медичної психології та психіатрії з курсом післядипломної освіти Вінницького національного медичного університету імені M. I. Пирогова. E-mail: oleksbelov@gmail.com. 
DOI 10.38129/Ann.Yur.Ist.2019.3.1.2.41

УДК 336.226.4

\title{
АКТУАЛЬНЫЕ ПРОБЛЕМЫ СОВРЕМЕННОГО НАЛОГООБЛОЖЕНИЯ В КОНТЕКСТЕ СООТНОШЕНИЯ ПУБЛИЧНЫХ И ЧАСТНЫХ ЦЕЛЕЙ
}

\author{
ЮЛИЯ ГАВРИЛЬЧЕНКО (Минск, Республика Беларусь) *
}

Собственность и культура сбережений берут начало в инстинкте самосохранения, свойственном всем живым существам. Стремление сберечь себя порождается осознанием своей индивидуальности, отделением «Я» от «не-Я». Инстинкты и жизненный опыт подсказывают оптимальные способы сохранения «Я» в целостности. При этом практически все биологические виды не только беспокоятся о сиюминутной безопасности, но организуют жизнь с определенной заботой о будущем.

Признание себя особой, но, тем не менее, конечной частью сложной окружающей действительности влечет стремление расширить свое «Я» и обеспечить его существование за счет объектов материального мира. Так возникают понятие «Мое» и желание сберечь не только Себя, но и сохранить Свое (как продолжение «Я»). В частности, с целью обеспечения продовольственной безопасности многие животные, особенно в условиях неблагоприятного климата, делают пищевые запасы. Так называемый инстинкт запасания кормов характерен для ряда насекомых, птиц, млекопитающих и др. При этом, животные с развитым коллективным началом формируют общие резервы, а «индивидуалисты» - частные.

Осознание принадлежности объекта (свое) - важный этап самоидентификации. В процессе социализации оно перерастает в противопоставление «свое-чужое» и в конечном итоге, уже в человеческом обществе, понятие владения расширяется до концепта «собственность».

Наличие объекта и осознание субъектом его принадлежности («Мое», «Наше») сами по себе не влекут появления собственности. Подобное осознание характерно как для человека, так и для некоторых других представителей животного мира. Собственность появляется именно в человеческом обществе, т.к. существование последнего обеспечивается особыми социальными регуляторами и, прежде всего, правом. Все фундаментальные характеристики собственности основаны на осознанном принятии ее неприкосновенности, вне защиты собственность становится эфремерной абстракциеи. Для возникновения права нет безусловной 
необходимости наличия государства в смысле союза людей, подчиненных государственной власти ${ }^{1}$.

Исследователи сходятся во мнении, что первоначально возникает колективная собственность как публичный ресурс. В раннепервобытной общине условиями выживания являются тесная кооперация, коллективная собственность на землю и уравнительное или равнообеспечивающее распределение. С повышением эффективности производства, появлением специализации, возникают прибавочный продукт и трудовое распределение, а впоследствии - и обмен. В литературе высказывается мнение, что появление частной собственности исторически связано с тем этапом развития человеческого общества, когда благодаря созданию более усовершенствованных орудий труда «количество произведенного прибавочного продукта превысило количество обычно потребляемого, т.е. появились излишки»². Данное высказывание, в общем справедливое применительно к западноевропейской изиилизаици, нельзя относить $к$ Востоку, где частная собственность появляется значительно позднее. Вместе с тем, оно вполне заслуживает внимания $b$ контексте сбережений и собственности у восточнославянских народов.

Мы полагаем, что превышение произведенного прибавочного продукта над обычно потребляемым («излищки») является не только результатом повышения производительности труда, но и следствием акта сбережения. Зарождение права колективной собственности начинается, когда каждый член общины осознает: запасы являются общими и распределяются согласно обычаю под страхом наказания. Способность и стремление присвоения части общинных сбережений, т.е. наличие (или возможность) индивидуальных сбережений и, соответственно, потребность в их защите, порождают категорию «частная собственность».

С появлением частной собственности происходит разделение публичного и частного элементов в категориях собственности и сбережений. Публичные сбережения становятся общественным (государственным) ресурсом. Сбережения домохозяйства (или индивидуума) признаются частным резервом.

1 Общая теория права: учеб. пособие / В. А. Абрамович [и др.]; под общ. ред. С. Г. Дробязко, С. А. Калинина. Минск : БГУ, 2013. С.101-102; Пэнто, Р. Методы соииальных наук / Р. Пэнто, М. Гравитц : пер. с фр.; под ред.: Казимирчук В.П. (Вступ. ст.), Туманов В.А. (Вступ. ст.); пер.: Боботов С. В., Глазов Ю. А. М. : Прогресс, 1972. С.53-54.

2 Калибернова, О. Н. Собственность и современное российское общество (общеправовой аспект) : дис... канд. юрид. наук: 12.00.01 / О.Н. Калибернова; Нижегородск. юрид. инст. Нижний Новгород, 1999. С.14. 
С момента этого разделения возникает классическая, существующая в любом государстве дихотомия, которая характеризуется диалектическим единством (и противоречием) частного и публичного.

С одной стороны, на всех этапах исторического развития отсутствует жесткий раздел между частным и публичным. Например, еще $b$ феодальный период государство сохраняло возможность использования сбережений населения на общественно значимые цели. В Великом княжестве Литовском достаточно активно частные сбережения привлекались для финансирования строительства дорог, мостов, защитных сооружений, для других общественно значимых целей. Массовые добровольные пожертвования в государственную казну не единожды имели место в период чрезвычайного положения вследствие войн, стихийных бедствий и в русской истории ${ }^{3}$.

С другой стороны, с развитием права (и особенно права частной собственности) все более актуальным становится максимальное ограничение возможностей изъятия публичной властью частных накоплений. Кульминацией эволюции современной концепции права частной собственности можно признать теорию естественного права, сорормулированную английскими фрилософами XVII в., а затем - французскими просветителями XVIII в., в соответствии с которой право частной собственности обвявляется прирожденным, данным от природы свойством, присущзим всякому человеку. Сбережения обретают полноценную правовую защиту. При этом предполагается, что для удовлетворения публичного интереса должны использоваться отдельные, публиные фронды.

Ученые полагают, что первоначально основной причиной возникновения публичных фондов стало появление в XVI в. потребности в концентрации ресурсов с целью «обеспечения наиболее насущных социальных и общеэкономических потребностей» и смысл понятийного содержания этих фондов как совокупности денежных средств, направленных на решение определенных социально-экономических целей и задач государства, не изменился в настоящее время4. Ряд проблем как общенаучного, так и прикладного характера возникает в связи с тем, что в определенном смысле к данному понятию могут быть отнесены и частные накопления.

3 Комягин Д. Л. К вопросу о понятии и классификации публичных доходов / Д. Л. Комягин / / Публично-правовые исследования. 2014. № 4. С. 77.

${ }^{4}$ Саттарова, А. А. Фонд как институт в финансовом праве : дис. ... канд. юрид. наук : 12.00.14 / А. А. Саттарова; Всероссийская гос. налог. акад. Министерсва финансов РФ. М., 2007. C. 24. 
Традиционно считается, что отношения, возникающие по поводу формирования публичных денежных фондов, охватываются правом государственных доходов. Несмотря на высказанное в литературе мнение о том, что формирование государственных доходов должно осуществляться в рамках частных имущественных отношений ${ }^{5}$ большинство авторов высказывается против использовании конструкции обязательства в финансовых отношениях, полагая, что «налоговое право тесно связано с гражданским, часто производно от него, но $b$ то же время автономно»6.

В силу применения в процессе регулирования метода принуждения формирование публичных фондов происходит исключительно на основании нормативных правовых актов, которые детально закрепляют права и обязанности субъектов 7 . Вместе с тем, в настоящее время существует тенденция расширения источников финансирования публичных нужд. В литературе подчеркивается, что некоторые публичные потребности могут покрываться за счет не бюджета, а частных средств либо децентрализованных финансов 8 . Для подобных ресурсов применяются различные названия: сборы, платежи, парафискалитеты, квазиналоги и т.д. ${ }^{9}$

Учитывая данный факт, А.А. Нечай полагает, что публичные фонды - это специально выделенная, относительно обособленная часть денежных средств, предназначенная для удовлетворения различных видов публичного интереса. Автор относит к ним кроме государственного бюджета государственные фонды страхования банковских вкладов населения, все виды фондов обязательного страхования, золотовалютные фонды и др. ${ }^{10}$ Н.В. Васильева отмечает, что могут создаваться частные фонды денежных средств для использования в целях финансирования социально-значимых расходов (например, фонды государственных

5 Иванов, А. А. Понятие «имущественные отношения» и проблемы налогового права / А. А. Иванов / / Вестник ВАС РФ. 2009. № 1. С. 76-77.

6 Карасева, М. В. Налоговое право России : новые аспекты правопонимания и развития / М. В. Карасева // Вестник ВГУ. Серия : Право. 2010. № 2. С. 238-239.

7 Дмитрик, О. А. Содержание и классификаиия фринансовых правоотномений / О. А. Дмитрик; под ред. Н. П. Кучерявенко. Харьков : Легас, 2004. С.75.

8 Артюхин, Р.Е. Казна и бюджет / Р. Е. Артюхин [и др.]; отв. ред.: Д. Л. Комягин. М. : Наука, 2014. С.218.

9 Крохина, Ю. А. Современные вопросы предмета финансового права / Ю. А. Крохина // Финансовое право (научно-практический журнал Украины). 2012. № 1. С. 4-8; Корнев, А.Д. Финансово-правовое регулирование парафискалитетов $b$ Российской Федерации: автореф. дис... канд. юр. наук: 12.00 .04 / А.Д. Корнев; Московский государственный юридический университет. Москва, 2017. С.14.

10 Нечай, А. А. Публичные фонды как системообразующая категория финансового права / А. А. Нечай / / Проблемы законности. 2010. № 11. С. 110-111. 
корпораций и компаний). Несмотря на гражданско-правовую конструкцию, они действуют не в частных интересах собственника, а в «неких общих, групповых, коллективных интересах (защита вкладов, создание высокотехнологичной продукции, пенсионное обеспечение и т.п.)»11.

Н.П. Кучерявенко подчеркивает, что в данном случае мы не переносим гражданско-правовые институты в финансовое право, а выделяем для финансово-правового регулирования то, что входит в сферу финансового права12. Продолжая эту мысль, С.В. Рыбакова характеризует институт «публичных финансов» не с точки зрения формы собственности, а с точки зрения публичного (общезначимого, общественного) интереса ${ }^{13}$.

В литературе высказываются опасения по поводу данного подхода. М.В. Карасева подчеркивает, что существование квазиналоговой системы приводит к постоянному росту парафискальных платежей. Автор отмечает актуализацию проблемы возмещения государством затрат негосударственных субъектов на осуществление публичных задач. 14

Как представляется, ключевым критерием негативизации в данном случае является обязательность уплаты сбора. Следует подчеркнуть, что добровольные безвозмездные поступления, хоть и могут быть отнесены к финансированию государственных расходов разных уровней 15 , и достаточно широко применялись на практике на протяжение всей истории ${ }^{16}$, не несут на себе подобного отягощения. С другой стороны, расширение системы обязательных парафискальных платежей создает дополнительную нагрузку на налогоплательщиков, что негативно сказывается не

11 Васильева, Н. В. Правовое регулирование публичных доходов / Н. В. Васильева. Иркутск: Изд-во БГУ, 2015. С.41-42.

12 Кучерявенко Н. П. Система финансового права: содержание, противоречия, перспективы / Н.П. Кучерявенко // Финансовыи механизм и его правовое регулирование: материалы Междунар. науч.-практ. конф. (24-25 апр. 2003 г.) / под ред. Е. В. Покачаловой, О. Ю. Бакаевой. Саратов: Саратовская академия права, 2003. Ч. 2. С. 4.

13 Рыбакова, С. В. Отдельные направления развития теории финансового права в аспекте определения предмета отрасли финансового права / С. В. Рыбакова // Вестник Южно-Уральского гос. университета. Серия : Право. 2009. № 17. С. 97.

14 Карасева, М. В. Некоторые тенденции развития финансово-правового регулирования на современном этапе / М. В. Карасева / / Вестник МГЮА. 2014. № 4. C. 77-79.

15 Пауль, А. Г. Система доходов бюджетов / А. Г. Пауль // Вестник ВГУ; серия Право. 2011. № 2. С. 378.

16 Ягодкина, В. А. Дополнительные источники финансовых средств государственных и муниципальных учреждений / В. А. Ягодкина // Финансовое право. 2014. № 11. С. 28. 
только на экономическом росте, но и на финансовой дисииплине. Более того, даже внесение минимальной степени принудительности в данном случае может иметь отрицательный эффект.

В частности, в литературе широко обсуждается такое неоднозначное явление, как самообложение граждан17. В Республике Беларусь оно может осуществляться на основании ст. 36 Закона Республики Беларусь от 4 января 2010 г. «О местном управлении и самоуправлении в Республике Беларусь»18. По сути самообложение означает добровольное принятие обязанности уплаты налога: граждане голосуют за введение того или иного обязательного местного платежа, признавая публичные цели продолжением своего частного интереса.

Тем не менее, на практике известны случаи использования данного института для злоупотреблений со стороны публичной власти. Например, при внедрении местного сбора или налога жители района опрашиваются на предмет возражений против нововведений. В почтовые ящики вбрасываются анкеты (или бланки заявлений), которые зачастую игнорируются гражданами. По результатам налог (сбор) вводится за неимением возражений. Такой подход совершенно недопустим, поскольку формализм и злоупотребления в самообложении становятся одной из причин недоверия граждан к публичной власти и, как результат, «обеспубличиванию» частного интереса.

Важно подчеркнуть, что проявление социальной ответственности не является редким явлением и может принести реальную пользу государству, обществу и гражданам. Например, в 2016 г. около 80 \% швейцарцев проголосовали на референдуме против введения безусловного базового дохода. Властями предлагалось внедрение ежемесячных выплат гражданам Швейцарии по 2,5 тыс. швейцарских франков (порядка 2,5 тыс. долларов) для взрослых и 625 франков для детей. Однако, осознавая тяжесть сопутствующей налоговой нагрузки и важность труда b иелом, швейцарцы

17 Киселев, И.А. Средства самообложения граждан в системе формирования доходов местных бюджетов / И. А. Киселев // Налоги и финансовое право. 2008. № 4. С. 225-230; Журавлева, О.О.Правовая природа самообложения / О. О. Журавлева // Финансовое право. 2012. № 10. С. 2-7; Черкасова, Ю. И., Плотникова, Н.Г. Правовые аспекты самообложения граждан / Ю.И. Черкасова, Н. Г. Плотникова / / Финансовое право. 2014. № 9. С. 26-30.

18 О местном управлении и самоуправлении в Республике Беларусь [Электронный ресурс]: Закон Республики Беларусь от 4 января 2010 г. № 108-3 : в ред. Закона от 04.01.2016 № 348-3 // ЭТАЛОН. Законодательство Республики Беларусь / Нац. центр правовой информ. Респ. Беларусь. Минск, 2018. 
отказались от этой заманчивой идеи.

Повышение социальной ответственности обусловило и активное развитие института краудфандинга (от англ. «сrowd»- толпа и «funding» финансирование). Краудфандинг - народное финансирование, т.е. объединение денежных ресурсов с целью поддержки какого-либо, как правило сочиально значимого, проекта. Следует согласиться с В.Л. Чугреевым, что краудфандинг является одним из ответвлений краудсорсинга, т.е. совместного добровольного участия ююдей $b$ решении общественно значимых задач19. В случае краудфандинга такое участие состоит, в первую очередь, в перечислении денежных средств.

Опыт сбора денег для осуществления общественно полезных проектов имеет глубокие исторические корни. М.О. Душина в данном контексте отмечает, что еще до появления интернета коммуникация по сетевому принципу сделала возможной многие научные открытия ${ }^{20}$. Наша история знает много примеров возведения важных объектов с активным привлечением средств населения, участия граждан в финансировании других публично значимых проектов (строительство Национальной библиотеки в Беларуси, др.).

В процессе становления информационного общества данная практика достигает своего расцвета. Сам термин «краудфандинг» появился в 2006 г., хотя первый краудфандинговый веб-сервис был официально зарегистрирован в США в самом начале 2000-х гг. ${ }^{21}$ Уже по итогам 2015 г. объем мирового рынка краудфандинга превысил 34 млрд. дол. и по оценкам экспертов к 2020 г. он может составить более 90 млрд долл.

На начальном этапе краудфандинг развивается именно как общественно значимая инициатива, поэтому большую часть проектов составляют благотворительные. В этом контексте он представляет собой непосредственное использование собственности на те публичные цели, которые сам собственник считает наиболее значимыми. Процесс аккумулирования сбережений специальными финансовыми институтами

19 Чугреев, В. Л. Создание краудсорсинг-проекта для публикации и обсуждения предложений по социально-экономическому развитию региона / В. Л. Чугреев / / Проблемы развития территории. 2012. № 62. С. 157.

20 Душина, М.О. Методы сетевой коммуникации в дигитальном обществе: бенчмаркинг, краудсорсинг, краудфандинг / М. О. Душина / / Социология науки и технологий. 2014. Т.5. № 1. С.105.

21 Mollick, E. The dynamics of crowdfunding: An exploratory study / E. Mollick // Journal of business venturing. 2014. Vol. 29. № 1. Р. 1; Патлис, В. В. Финансирование стартапов: теория вопроса / В.В.Патлис // Веснік Беларускага дзяржаунага эканамічнага універсітэта. 2016. № 2. С. 51. 
или государственное участие в публичном интересе в данном случае пропускаются. Накопления сразу и напрямую инвестируются в общественное развитие (в его понимании сберегателем).

Можно утверждать, что любая благотворительная помощь в определенной степени является способом использования публичного сберегательного ресурса. Однако применительно к краудфандингу одной из изелей становится именно всеобщая польза. Так, в случае помощи людям с ограниченными возможностями речь идет о новых аспектах безбарьерной среды, новачионном виде инклюзивного образования, организации спортивной команды и пр. Возможна поддержка отдельных людей, но лишь как средство достижения публичной изели.

В настоящее время краудфандинг отягощен рядом проблем, ключевой из которых является недостаточная защищенность прав инвесторов. Существующее правовое регулирование не предусматривает механизмов привлечения к ответственности авторов проекта, допустивших нарушения в процессе привлечения ресурсов, их распределении и реализации самого проекта. В результате даже на самых строгих краудфандинговых платформах остается большая доля проектов, которые, несмотря на полное инвестирование, даже не были начаты. Национальный банк Республики Беларусь активно работает над разработкой нормативного правового акта, регулирующего эти вопросы, однако пока проблема не имеет однозначного решения.

Тем не менее, само активное развитие краудфандинга свидетельствует о важности публичного компонента в институте частной собственности и высокой социальной ответственности людей по всему миру. Например, белорусские краудфандинговые платформы ориентированы в подавляющем большинстве на социальные проекты. Исключительно благотворительным «МаеСэнс», функционирующий с 2011 г. (maesens.by) C 2013 г. работает «Талакошт» (talaka.by). Особое место на рынке краудфандинга занимает коммерческая краудфандинговая платформа «Улей» (ulej.by), действующая по принципу известного «Kickstarter» и аккумулировавшая только за первые полгода функционирования (с апреля 2015 г.) около полумиллиарда белорусских рублей.

Важно подчеркнуть, что частная собственность и сбережения населения не могут быть признаны публичным фондом в понимании классического финансового права. Это было бы в корне ошибочным, создав теоретическую возможность для принудительного участия сбережений граждан в финансировании государственных расходов. Подобный подход, примененный в советский период, уже доказал свою неэффективность для 
реализации как частных, так и публичных интересов. Фактическая национализация дореволюционных сбережений уничтожила доверие к организованным накоплениям. Потребовались многие усилия для восстановления сберегательной традиции, которая так и не смогла полноценно трансформироваться в сберегательную культуру в условиях доминирования публичного интереса над частным.

В современный период важнейшей проблемой становится поиск баланса между частными и публичными целями в процессе правового регулирования. В литературе представлены попытки определения публичных целей через категорию интереса (от лат. interest - имеет значение, важно). Такой подход применяется достаточно часто, в различных отраслях научных знаний (философия, история, психология, управление, педагогика, юриспруденция). Публичный интерес относят к ключевым признакам публичности ${ }^{22}$. Так, П.М. Годме определяет публичные финансы как средство осуществления общего интереса ${ }^{23}$.

Понятие публичного интереса достаточно подробно исследовано, однако оно не является определенным и даже отождествляется с понятиями «частные отношения», «частное право» 24 . Ученые указывают на связь между публичным интересом, общественной пользой 25 и потребностями общества ${ }^{26}$.

Как представляется, применительно к собственности определяющим является соотношение публичного и общественного. Как общественными, так и публичными в анализируемой ситуации признаются социальные, экономические и другие общие нужды (в том числе нужды государства как своего рода менеджера). В русскоязычной литературе отмечается «исторически сложившееся отождествление терминов «государственное» и «публичное» 27. Однако данное отождествление неприменимо для других зарубежных стран: publiquе и public не значит государственный. Например, английское понятие state (государство,

22 Саурин, А. А. К вопросу о понятии «публичная собственность» / А. А. Саурин // Юридический мир. 2013. № 2. C. 8.

${ }^{23}$ Годме, П. М. Финансовое право / П. М. Годме ; пер., вступ. ст. : Халфина Р. О. М. : Прогресс, 1978. С.77.

24 Козлова, В. Н. Понятие публичных и частных интересов и их соотношение / В. Н. Козлова // Государственная власть и местное самоуправление. 2011. № 7. С. 36.

25 Шарнина, Л. А. Частные и публичные интересы в конституционном праве / Л. А. Шарнина // Конституизионное и муниципальное право. 2005. № 4. С. 4-6.

26 Рау, К. Г. Основные начала финансовой науки / К. Г. Рау; пер. с пятого нем. изд.; под ред. А. Корсака. Т. 1-2. СПб. : Книга по Требованию, 2012. С.3.

27 Васянина, Е. Л. Правовой режим государственных доходов на современном этапе развития финансового законодательства / Е. Л. Васянина // Налоги u финансовое право. 2012. № 11. C.207. 
государственный) в исследуемом контексте не употребляется. Интерес, цели, отношения, ресурсы являются именно публичными (public). Государство в такой интерпретации выступает не в качестве самостоятельного субъекта общественных отношений, а лишь как представитель интересов общества, уполномоченный выполнять некоторые функции. «Публичное право изначально является общим достоянием, обшим благом граждан, государству оно иишь делегируется как органу гражданской нации» 28.

Современные исследователи отмечают, что общественные интересы должны преломляться через деятельность государства ${ }^{29}$. Однако было бы $b$ корне неверным отождествлять публичный и государственный интересы: «публичный интерес не только не тождествен государственному, но может даже противоречить ему» ${ }^{30}$.

Таким образом, публичный характер целей сбережений населения не означает их идентичности целям государства, а лишь предполагает обязательный учет последних в определении условий существования накоплений как публичного ресурса. В данном контексте реализация публичных целей также не предусматривает обязательного перехода накоплений в распоряжение государства и участия государства в сберегательном процессе.

В.Н. Козлова формулирует следующие отличительные признаки публичных интересов: принадлежат не отдельным лицам, а обществу или их идеальному единству; относятся к численно неопределенной массе людей; их реализация является условием реализации частных интересов ${ }^{31}$. О.Ю. Кравченко подчеркивает, что публичный интерес может преобразовываться в частный интерес универсального характера 32. Исследуя связь между публичным и частным интересами, Ю.А. Тихомиров называет публичный интерес концентрированным социальным обязательством публичных органов перед обществом, подчеркивая, что он не только обеспечивает устои общества и государства, но и гарантирует

28 Казанцев, Н. М. Метод финансового права: переосмысление / Н. М. Казанцев / / Журнал российского права. 2012. № 6 (186). С.48.

29 Курбатов, А.Я. Сочетание частных и публичных интересов при правовом регулировании предпринимательской деятельности / А. Я. Курбатов. М.: ЮрИнфоР, 2001. 212 c.

30 Раскотиков, И. С. Публичные и частные интересы в финансовом и налоговом праве / И. С. Раскотиков / / Гражданин и право. 2014. № 10. С.67-74.

31 Козлова, В. Н. Понятие публичных и частных интересов и их соотношение / В. Н. Козлова // Государственная Власть и местное самоуправление. 2011. № 7. С. 37.

32 Кравченко, О.Ю. Публичные и частные интересы $b$ праве: политико-правовое исследование : автореф. дис. ... канд. юр. наук : 12.00 .01 / О. Ю. Кравченко ; Казанский государственный университет. Казань, 2004. С.9. 
удовлетворение частных интересов в их единичном и концентрированном («усредненном») выражении ${ }^{33}$.

В литературе в данном контексте используется понятие «общеполезности» 34 .

Мы полагаем, что понятие «общий» не является определяющим в данном случае. Гораздо важнее именно сочетание интереса индивидуального и коллективного. Таким образом, публичные изели - это стремление к удовлетворению возникающих как продолжение и развитие частных интересов в обществе и государстве, признанных публичной властью потребностей неопределенного круга мии, которое обеспечивает существование и прогресс соииума, а также государственное развитие. Подобное определение публичных целей предполагает, что публичный интерес может быть не только у государственных финансов, но и у частных, допуская и поощряя активное участие граждан в достижении публичных целей. Это способствует развитию общества и государства и отвечает частным интересам, способствуя защите прав и свобод человека.

\section{ЛИТЕРАТУРА}

1. Артюхин, Р.Е. Казна и бюджет / Р.Е. Артюхин [и др.]; отв. ред.: Д.Л. Комягин. - М. : Наука, 2014. - 501 с.

2. Васильева, Н. В. Правовое регулирование публичных доходов / Н. В. Васильева. - Иркутск : Изд-во БГУ, 2015. - 194 с.

3. Васянина, Е.Л. Правовой режим государственных доходов на современном этапе развития финансового законодательства / Е. Л. Васянина // Налоги и финансовое право. - 2012. - № 11. - С. 207.

4. Дмитрик, О. А. Содержание и классификаци финансовых правоотношений : моногр. / О. А. Дмитрик; под ред. Н. П. Кучерявенко. Харьков : Легас, 2004. - 157 с.

5. Душина, М. О. Методы сетевой коммуникации в дигитальном обществе : бенчмаркинг, краудсорсинг, краудфандинг / М. О. Душина // Социология науки и технологий. - 2014. - Т.5. - № 1. - С.105-115.

6. Журавлева, О. О. Правовая природа самообложения / О. О. Журавлева // Финансовое право. - 2012. - № 10. - С. 2-7;

7. Иванов, А. А. Понятие «имущественные отношения» и проблемы налогового права / А. А. Иванов / / Вестник ВАС РФ. - 2009. - № 1. - С. 76-82.

33 Тихомиров, Ю. А. Современное публичное право : монографический учебник / Ю. А. Тихомиров. Институт законодательства и сравнительного правоведения при Правительстве Российской Федерации. Москва: Эксмо, 2008. С.140.

34 Кряжков, А. В. Публично-правовые и частноправовые начала в деятельности Агентства по страхованию вкладов / А. В. Кряжков // Журнал российского права. 2013. № 1. C. 20. 
8. Казанцев, Н. М. Метод финансового права: переосмысление / Н. М. Казанцев / / Журнал российского права. - 2012. - № 6 (186). - С.48.

9. Карасева, М. В. Налоговое право России : новые аспекты правопонимания и развития / М. В. Карасева // Вестник ВГУ. Серия : Право. - 2010. - № 2. - С. $238-$ 248.

10. Карасева, М. В. Некоторые тенденции развития финансово-правового регулирования на современном этапе / М. В. Карасева // Вестник МГЮА. 2014. - № 4. - С. 74-79.

11. Киселев, И.А. Средства самообложения граждан в системе формирования доходов местных бюджетов / И. А. Киселев // Налоги и финансовое право. - 2008. - № 4. - С. 225-230.

12. Козлова, В.Н. Понятие публичных и частных интересов и их соотношение / В.Н. Козлова // Государственная власть и местное самоуправление. - 2011. - № 7. - С. 35-38.

13. Комягин Д. Л. К вопросу о понятии и классификации публичных доходов / Д. Л. Комягин // Публично-правовые исследования. - 2014. - № 4. - С. 60-93.

14. Корнев, А. Д. Финансово-правовое регулирование парафискалитетов в Российской Федерации: автореф. дис... канд. юр. наук : 12.00 .04 / А.Д. Корнев ; Московский государственный юридический университет. - Москва, 2017. - 27 с.

15. Крохина, Ю. А. Современные вопросы предмета финансового права / Ю. А. Крохина // Финансовое право (научно-практический журнал Украины). 2012. - № 1. - С. 4-8.

16. Кряжков, А. В. Публично-правовые и частноправовые начала в деятельности Агентства по страхованию вкладов / А. В. Кряжков // Журнал российского права. - 2013. - № 1. - С. 17-20.

17. Курбатов, А. Я. Сочетание частных и публичных интересов при правовом регулировании предпринимательской деятельности / А. Я. Курбатов. М. : ЮрИнфоР, 2001. - 212 с.

18. Кучерявенко Н.П. Система финансового права: содержание, противоречия, перспективы / Н. П. Кучерявенко // Финансовый механизм и его правовое регулирование: материалы Междунар. науч.-практ. конф. (24-25 апр. 2003 г.) / под ред. Е. В. Покачаловой, О. Ю. Бакаевой. - Саратов: Саратовская академия права, 2003. - Ч. 2. - С. 3-8.

19. Нечай, А. А. Публичные фонды как системообразующая категория финансового права / А. А. Нечай // Проблемы законности. - 2010. - № 11. - С. 109-115.

20. О местном управлении и самоуправлении в Республике Беларусь [Электронный ресурс] : Закон Республики Беларусь от 4 января 2010 г. № 108-3 : в ред. Закона от 04.01.2016 № 348-3 // ЭТАЛОН. Законодательство Республики Беларусь / Нац. центр правовой информ. Респ. Беларусь. - Минск, 2017.

21. Общая теория права : учеб. пособие / В. А. Абрамович [и др.]; под общ. 
ред. С. Г. Дробязко, С. А. Калинина. - Минск : БГУ, 2013. - 416 с.

22. Патлис, В. В. Финансирование стартапов : теория вопроса / В. В. Патлис // Веснік Беларускага дзяржауннага эканамічнага універсітэта. - 2016. - № 2. - С. 51-57.

23. Пауль, А. Г. Система доходов бюджетов / А. Г. Пауль // Вестник ВГУ; серия Право. - 2011. - № 2. - С. 370-380.

24. Пэнто, Р. Методы социальных наук / Р. Пэнто, М. Гравитц : пер. с фр.; под ред.: Казимирчук В.П. (Вступ. ст.), Туманов В.А. (Вступ. ст.); пер.: Боботов С. В., Глазов Ю. А. - М. : Прогресс, 1972. - 607 с.

25. Раскотиков, И.С. Публичные и частные интересы в финансовом и налоговом праве / И. С. Раскотиков / / Гражданин и право. - 2014. - № 10. - С. 6774.

26. Рау, К. Г. Основные начала финансовой науки / К. Г. Рау ; пер. с пятого нем. изд. ; под ред. А. Корсака - Т. 1-2. - СПб. : Книга по Требованию, 2012. - 560 с.

27. Рыбакова, С. В. Отдельные направления развития теории финансового права в аспекте определения предмета отрасли финансового права / С. В. Рыбакова // Вестник Южно-Уральского гос. университета. Серия : Право. 2009. - № 17. - C. 95-100.

28. Саттарова, А. А. Фонд как институт в финансовом праве : дис. ... канд. юрид. наук: 12.00.14 / А. А. Саттарова ; Всероссийская гос. налог. акад. Министерсва финансов РФ. - М., 2007. - 189 с.

29. Саурин, А. А. К вопросу о понятии «публичная собственность» / А. А. Саурин / / Юридический мир. - 2013. - № 2. - С. 8-12.

30. Тихомиров, Ю.А. Современное публичное право:монографический учебник / Ю.А. Тихомиров ; Институт законодательства и сравнительного правоведения при Правительстве Российской Федерации. - Москва : Эксмо, 2008. -446 с.

31. Черкасова, Ю. И., Плотникова, Н. Г. Правовые аспекты самообложения граждан / Ю. И. Черкасова, Н. Г. Плотникова // Финансовое право. - 2014. - № 9. $-26-30$.

32. Чугреев, В.Л. Создание краудсорсинг-проекта для публикации и обсуждения предложений по социально-экономическому развитию региона / В. Л. Чугреев / П Проблемы развития территории. - 2012. - № 62. - С. 157-164.

33. Шарнина, Л. А. Частные и публичные интересы в конституционном праве / Л. А. Шарнина // Конституционное и муниципальное право. - 2005. № 4. - C. 4-6.

34. Ягодкина, В. А. Дополнительные источники финансовых средств государственных и муниципальных учреждений / В. А. Ягодкина / / Финансовое право. - 2014. - № 11. - С. 26-29.

35. Mollick, E. The dynamics of crowdfunding: An exploratory study / E. Mollick / / Journal of business venturing. - 2014. Vol. 29. - № 1. - P. 1-16. 
Dr. Prof. Yulia Gaurylchenko (Minsk, Belarus)

\section{CURRENT PROBLEMS OF MODERN TAXATION IN THE CONTEXT OF THE RELATIONSHIP OF PUBLIC AND PRIVATE GOALS}

Abstract. The article is devoted to the most important issue of modern tax policy. The author focuses on the correlation of individual and public interest. Various practices of self-taxation are analyzed. Approaches to the definition of crowdfunding and public goals are proposed. Some cases from the relevant legal practice of the Republic of Belarus are described.

Key-words: Taxes, Self-Taxation, Crowdfunding, Public Interest, Public Purpose.

проф. Юлия Гаврильченко (Минск, Беларусь)

\section{АКТУАЛЬНЫЕ ПРОБЛЕМЫ СОВРЕМЕННОГО НАЛОГООБЛОЖЕНИЯ В КОНТЕКСТЕ СООТНОШЕНИЯ ПУБЛИЧНЫХ И ЧАСТНЫХ ЦЕЛЕЙ}

Аннотация. Статья посвящена важнейшему вопросу современной налоговой политики. В центре авторского внимания корреляция индивидуального и публичного интереса. Анализируются различные практики самообложения. Предложены подходы к определению краудфандинга и публичных целей. Описаны некоторые случаи из соответствующей юридической практики Республики Беларусь.

Ключевые слова: налоги, самообложение, краудфандинг, публичный интерес, публичная цель.

проф. Юлія Гаврильченко (Мінськ, Білорусь)

\section{АКТУАЛЬНІ ПРОБЛЕМИ СУЧАСНОГО ОПОДАТКУВАННЯ В КОНТЕКСТІ СПІВВІДНОШЕННЯ ПУБЛІЧНИХ ТА ПРИВАТНИХ ЦІЛЙ}

Анотація. Стаття присвячена важливому питанню сучасної податкової політики. У центрі авторської уваги знаходиться кореляція індивідуального і суспільного інтересу. Аналізуються різні практики самооподаткування. Запропоновано підходи до визначення краудфандингу і публічних цілей. Описано деякі випадки з відповідної юридичної практики Республіки Білорусь.

Ключові слова: податки, самооподаткування, краудфандинг, публічний інтерес, публічна мета.

* Гаврильченко Юлія Петрівна - доктор юридичних наук, доцент, доцент кафедри фінансового права i правового регулювання господарської діяльності юридичного факультету Білоруського державного університету (Мінськ, Білорусь). E-mail: yuliyadovnar@rambler.ru. 
DOI 10.38129/ Ann.Yur.Ist.2019.3.1.2.55

УДК 94(476+477) | 19|(08)

\title{
ДИПЛОМАТИЧЕСКИЕ ОТНОШЕНИЯ БНР И ПРАВИТЕЛЬСТВА ПАВЛА СКОРОПАДСКОГО (1918)
}

\author{
АЛЕКСАНДР КУКСА (Минск, Республика Беларусь)*
}

В свете событий Февральской революции и последовавшей борьбы за автономный статус Украины в составе России, Минск, как центр Западного фронта, на котором находилось около 100 тысяч солдат-украинцев, приобретал все большее значение для Украинской Центральной рады (УЦР). Как позже указывал на встрече с корреспондентами в КаменцеПодольском заместитель посла Белорусской Народной Республики в Украине А. Головинский, именно в Минской губернии С. В. Петлюра начал создавать первые национальные военные формирования.

В помещении медицинского бюро Земского союза 28 марта 1917 г. состоялось общее собрание украинцев, в котором приняли участие около 300 солдат, офицеров, работников фронтовых общественных организаций и жителей Минска. Председатель собрания С. В. Петлюра призвал собрание к организации украинских сил на фронте, ибо «только организованный народ сможет использовать ту свободу, которую теперь получил, и закрепить свои политические и национальные права, которые наиболее полно смогут выявиться при демократически-республиканском и федеративном устройстве России, с автономной Украиной» [1, с. 2]. Для проведения в жизнь своих постановлений собрание признало необходимым создавать украинские кружки, войти в сношения с Украинской Центральной Радой и с местными организациями - Советами рабочих и солдатских депутатов, Солдатско-офицерской комиссией, Белорусским комитетом и другими. Было принято решение провести в Минске и на фронте несколько украинских митингов, организовать с целью сбора средств на фронтовые организации «День вільної України», опубликовать воззвание с призывом к организации. В Совет Минской громады, выделенный на собрании, вошли 20 чел.

В июне 1917 г. в Минске был создан Временный Украинский комитет Западного фронта. Под его руководством среди украинских солдат распространялись брошюры, газеты и листовки, в которых звучал призыв создать национальные воинские части. В помещении фронтового комитета 
10 июля 1917 г. состоялось общее собрание около 600 членов украинской громады под председательством К. Новохацкого. После прочтения 2-го универсала УЦР, постановлений Временного правительства и произнесения речей, поясняющих эти акты, была принята резолюция, в которой собрание постановило: «поддерживать всеми способами, созданные революционной демократией и уполномоченные ею органы революционной власти, как на Украине, так и в России вообще, в их борьбе за укрепление завоеваний революции» [2, с. 2].

На 1-м съезде украинских организаций начала работу Украинская рада Западного фронта (УРЗФ), которой поручалось вступить в контакт с Белорусским национальным комитетом (БНК). Присутствовавший на съезде представитель Белорусской социалистической громады (БСГ) Л. И. Заяц заявил о необходимости сближения белорусских и украинских организаций и сообщил о возможности оказания поддержки, в виде предоставления Украинской громаде помещения в Белорусской хатке.

Украинские организации повели активную деятельность на территории Белоруссии. УРЗФ организовала свое помещение в Минске, расположив там библиотеку, установила мебель, приобрела канцелярские принадлежности. После разгрома этого помещения большевиками в декабре 1917 г., УРЗФ оценила потерю имущества в значительную для того времени сумму - 22000 руб.

Белорусские и украинские политические организации включились в общую работу по подготовке населения к демократическим и федеративным преобразованиям. Украинские партии эсеров (УПСР), федералистов (УПСФ), демократов (УПСД) и БСГ провели ряд митингов, общественных сходов и праздников, выступили одним блоком на выборах в органы местного самоуправления. Но 30 июля 1917 г. блок национальных социалистических партий потерпел ощутимое поражение на выборах в Минскую городскую думу, проведя только 4-х депутатов. В Минскую думу попали лишь два представителя от белорусских партий и то только потому, что одно место им уступили представители украинских партий.

В декабре 1917 г. между РСФСР и Украинской Народной Республикой (УНР) началась война. Текст ответа УНР о неправомерности действий СНК РСФСР против Украины был распространен Украинской фронтовой радой среди солдат Западного фронта с призывом поддержать УНР. Руководители Областного исполнительного комитета (Облискомзапа) Западного фронта, среди членов которого белорусов не было, восприняли ноту Генерального секретариата, информацию в белорусской печати и 
обращение М. М. Лебединца* как факт создания реальной угрозы для советской власти. В связи с этим А. Мясников в начале декабря 1917 г. запретил выделение украинских национальных частей, а в случае движения их на Юг приказал задерживать, устроив заслоны на станциях Минск, Лунинец и Сарны.

Из письма председателя Украинской фронтовой рады М. М. Лебединца к правительству УНР следует, что он и весь состав УРЗФ 7 декабря 1917 г. были арестованы Облискомзапом. Под арестом находились до 17 февраля 1918 г. После ареста членов рады в Минске была создана следственная комиссия при СНК Западной области и фронта в составе: К. Г. Кнорин, С. И. Берсон и П. П. Осипов. Всего арестовали 9 человек, из которых членами рады УРЗФ являлись: А. Я. Ермак, М. И. Спасский, П. Д. Косяк, М. М. Лебединец и А.Г.Золотницкий. Аресты на этом не прекратились. В Минск продолжали прибывать делегаты на Всебелорусский съезд.

Под предлогом подготовки восстания Центральной белорусской войсковой радой совместно с польским корпусом Довбор-Мусницкого (появилась информация о выделении УНР белорусам 11 тыс. руб. на создание армии), прибывавшие делегаты от Юго-Западного фронта арестовывались. В январе 1918 г. ЦБВР и органы местного самоуправления были распущены Облискомзапом.

В феврале 1918 г. возобновляются военные действия на Восточном фронте. Немецкие войска оккупировали Минск и большую часть Белоруссии. Учитывая предшествующие события и отсутствие помощи и защиты со стороны белорусов, члены УРЗФ введя в свой состав председателя Украинской минской громады К. Новохацкого и ее члена

\footnotetext{
* Лебединец Михаил Моисеевич, 28 лет, прапорщик, председатель фронтовой войсковой украинской рады, член УПСР. На вопрос о том, признает ли он власть Центрального СНК и местную советскую власть ответил, что он эту власть на месте признает, а что же касается Украины, то там он признает власть поставленную украинским народом - Центральную Раду. На вопрос о его действиях в случае начала открытого военного конфликта между УЦР и правительством СНК, Михаил Моисеевич заявил, что украинские части должны выполнять приказы УЦР. На вопрос о том, знает ли он о вызове в Минск украинских войск - ответил отрицательно. На вопрос «было ли выпущено воззвание к украинскому народу?» ответил, что на съезде украинских социалистов в Минске 6 декабря был выработан и разослан по телеграфу ответ на ультиматум правительства СНК правительству Украинской республики, к которому присоединилась и фронтовая украинская рада.
} 
В. Ситника, 21 февраля 1918 г. организовали «Мінський Комітет Охорони інтересів і прав підданих УНР». В состав комитета входили: М. Лебединец (председатель), К. Новохацкий (заместитель), М. Спасский (секретарь), А. Стасюк (казначей) и В. Ситник (член).

23 февраля 1918 г. Комитет провел общее собрание украинцев городской колонии, на котором организовали добровольный сбор денег и возобновили деятельность Минской Громады. Эти организации работали в тесном контакте: Громада принимала украинцев в свои члены, собирая за это членские взносы, а Комитет организовал стол по выдаче справок о подданстве УНР, тем кто «пред'явив у цей стіл картку від Міської Української Громади й давав свою власноручно підписану заяву в тому, що він визнає на Україні лише владу Центральної Ради та ії виконавчого органу - Ради Народних Міністрів» [4, л. 144]. Благодаря сотрудничеству немецких военных властей за месяц удалось отправить 2500 человек на Украину. О том, что немецкое командование было заинтересовано в переброске на территорию Украины именно военнообязанных, свидетельствует тот факт, что с первыми двумя эшелонами отправились только 500 гражданских лиц, а в дальнейшем Комитету запретили вообе включать их в списки. В письме к правительству УНР М. М. Лебединец сообщал не только о деятельности этих организаций но и давал характеристику белорусскому движению, указывая на слабость БНР и говоря о Минском комитете как о консульстве: «як видно з детального огляду праць Комітету Охорони та його завдань він в певній мірі виконував майже всі функції Консульства й усіма за консульство й лічився, не дивлячись на те, що не носив офіційно сієї назви» [4, л. 145].

Выехавшая из Минска в марте 1918 г. делегация БНР, в апреле провела ряд встреч с лидерами УЦР непосредственно в Киеве. По итогам этих встреч украинский премьер-министр В. Голубович 10 апреля выступил с докладом на заседании Рады народных министров. В докладе он информировал о провозглашении независимости Белоруссии, необходимости установления прочной связи с Минском и необходимости выделения займа в 500 тыс. руб. В ходе дискуссии по вопросу признания независимости БНР, С. Шелухин заявил, что это зависит от Украинской Центральной рады. М. Ткаченко предложил послать в Белоруссию специальных делегатов для ознакомления с ситуацией на месте, а Сидоренко заявил, что Министерство иностранных дел должно сначала выяснить отношение к этому вопросу заинтересованных государств. В итоге вопрос был снят с обсуждения, но Министерству иностранных дел поручили ответить, что «Рада народних міністрів принципово нічого не 
має проти признання Білоруської Народної Республіки незалежною і буде вживати заходів до переведення цієї справи в життя законним шляхом» [5, с. 262]. В то же время острая необходимость в топливе подталкивала Раду народных министров к установлению контактов с белорусской делегацией. На предложение белорусов о продаже дров, 15 апреля 1918 г. постановили выдать авансом 300 тыс. руб. в счет их стоимости. Впрочем, временно исполняющий обязанности Государственного контролера Симонов резонно заметил, что поскольку БНР не признается как государство, то и торговую операцию не с кем тогда официально оформить.

Некоторые успехи киевской миссии БНР и сложность продовольственного вопроса в Минске заставляли украинский Минский комитет более активно искать пути налаживания контактов с УНР. За апрель 1918 г. в Киев были направлены три человека с отчетами о деятельности украинского комитета в Минске. Но связь так и не удавалось наладить, так как посланцы не возвращались. Наиболее удачной оказалась поездка заместителя председателя Минской украинской громады А. М. Квасницкого. МИД Украины препроводило посланца к И. И. Красковскому, с которым и были обсуждены вопросы поставки вагонов для вывоза украинских беженцев на родину. По всей видимости, эта встреча и основные направления деятельности Комитета предшествовали открытию в Минске дипломатического представительства Украины.

В мае 1918 г. председатель Минской украинской громады К. Новохацкий в письме ${ }^{*}$ МИД Украинской Державы указывал на то, что в связи с отсутствием возможности связаться по телеграфу, участники громады отправляют в Киев заместителя председателя Квасницкого и Ветринского. Срочность вопроса связана с тем, что в Минске тогда собралось около 3000 украинцев. В то же время, из России на Минск и Оршу предполагалось отправление большой группы украинцев (только из Козловского уезда Тамбовской губернии направлялось 20000 бывших жителей Холмской губернии). В свою очередь, немецкие власти заявили, что вагонов нет и не будет. Сложным было положение тех, кто уже прибыл в Минск: «військових, німці хоч і мало, але годують, а цивільним допомагати одмовили. На мої прохання відповідають, що без санкції українського уряду нічим допомогти не можуть» [6, л. 2-2 об].

\footnotetext{
* Письмо дошло в Киев 3 июня. После обработки оно было переадресовано Красковскому, о чем свидетельствует резолюция на письме, поставленная карандашом от руки.
} 
По сведениям А. М. Квасницкого, в лучшем положении находились несколько сот украинцев, которым была предоставлена небольшая продовольственная помощь. Сообщая о тяжелом материальном положении украинцев, А. М. Квасницкий указывал на то, что 150 обедов выдавалось бесплатно Украинской раде ежедневно органами местного самоуправления.

3 мая 1918 г. новое украинское правительство гетмана Павла Скоропадского принимает решение основать украинское консульское агентство первого разряда в Минске (во главе с А. М. Квасницким). Деятельность агентства началась 19 мая и должна была проходить в тесном контакте с правительством БНР. Об этом свидетельствует сообщение Квасницкого, что большие надежды на консульство возлагали белорусские общественные организации. Перед отъездом из Киева А. М. Квасницкий беседовал с белорусскими представителями, которые заявляли, что надеются на него «как прожившего 17 лет в разных местностях Белоруссии». Представители биржи и общества землевладельцев в Минске также «обещали придти на помощь» в налаживании экономических контактов с Украиной. В то же время, министр иностранных дел Украины указывал на то, что консульские представительства нужны были для охраны торговых интересов и для «возвращения украинских граждан, главным образом, из мест бывшей Российской империи» [7, л. 9].

Сведения о событиях на Украине, связанных с государственным переворотом, в результате которого к власти пришел гетман Павел Скоропадский, поступили в Минск только 4 мая 1918 г. Украинская колония в Минске была застигнута новой киевской властью совершенно не подготовленной. В помещении Украинской Рады в Минске 5 мая состоялось совещание представителей правления Украинской Рады, в котором по особому приглашению принимал участие и председатель Народного секретариата БНР. Совещание это «не вынося конкретных решений, подготовило почву для будущих совещаний, имеющих состояться официально» [8, л. 26 об]. После возвращения в Минск 3 июня А. М. Квасницкий посетил председателя Народного секретариата И. Я. Воронко, изложив цель своего назначения и свою роль в столице Белоруссии. Беседа председателя Народного секретариата с украинским консулом длилась около часа. На приеме присутствовал управляющий делами народного секретариата Л. И. Заяц. В это же время появляется сообщение о назревшей необходимости открытия в Москве БелорусскоУкраинской торговой палаты.

В связи с назначением в Минске украинским консулом 
А. М. Квасницкого киевская миссия БНР обратилась 11 мая к правительству Украины с предложением назначить белорусского консула в Киеве. Кандидатом предлагали доктора П. В. Тремповича, который стал 29 мая консулом БНР в Киеве (с 16 июня 1918 г. генеральным консулом являлся Г. Ф. Базаревич). До этого обязанности консульства исполняла Белорусская торговая палата. В связи с этими событиями А. И. Цвикевич заявил, что в факте вступления политических структур Украины в переговоры с представителями Рады БНР последние усмотрели скрытый акт признания белорусской независимости. А. И. Цвикевич призывал гетмана «продолжить переговоры и поддержать стремление БНР получить признание от Советской России» [10, л. 4]. 21 мая 1918 г. Народный секретариат БНР определился со своей позицией относительно гетманского правительства. Главной внешнеполитической задачей провозглашалось установление добрососедских отношений с Украиной. Народный секретариат БНР призывал установить правильную пограничную линию на основе этнического принципа, а также с учетом исторических, экономических и географических факторов. На этом фоне происходит политическая активизация украинских белорусов, особенно проживавших в Одессе и вокруг неё.

В отчете временного консула Украинского государства в Минске А. М. Квасницкого перед Министерством иностранных дел от 30 мая 1918 г. указывалось, что в Минск ежедневно прибывало 50-100 украинцев, которых война в большом количестве забросила в пределы Белоруссии, Польши и Литвы. Большинство, узнав об украинском консульстве, пробирались в Минск для того, чтобы с его помощью получить пропуск от немецкой власти для проезда в Украину. Всего в Минске собралось около 4000 украинцев с семьями. Вместе с генералом Московенко и полковником Половинцем, 23 мая 1918 г. Квасницкий посетил представителей немецкой власти, которые отнеслись к ним с большим уважением: «довідавшись про те, що я командирований новим урядом, німецька влада запевнила мене, що наші тут відносини будуть щирими і дружніми, і будуть засновані на взаємній ввічливості та услузі» [9, л. 1]. Уже 24 мая 90 офицеров и 300 казаков отправились военным эшелоном в Украину.

Вторым фактором, но не менее важным в годы разрухи, являлись экономические отношения. А. М. Квасницкий сообщал, что значительная часть белорусского леса находила свой рынок сбыта на территории Украины, взамен чего Белоруссия получала зерно и сахар. Важность природных богатств Белоруссии для экономики Украины подтверждала и Белорусская торговая палата в Киеве, которая сообщала, что ежедневно 
поступали заявления от общественных учреждений горнопромышленного угольного района, кооперативов, городов и земств, указывавших на свое критическое положение из-за отсутствия топлива и крепежного материала.

В августе 1918 г., в связи с подписанием Добавочного договора между Германией и Россией, планируемое освобождение территорий Беларуси и Украины немецкими войсками поставили в неопределенное положение вопрос о белорусско-украинском сотрудничестве. Украинской стороной ставится под сомнение деятельность Белорусской торговой палаты, вопрос о признании суверенитета Белоруссии откладывается. Белорусская делегация заявляет о прекращении переговоров и уезжает в Минск.

В то же время, завершившиеся ничем в сентябре 1918 г. украинскороссийские переговоры и явное нежелание СНК РСФСР признавать национальные правительства Белоруссии и Украины заставляли искать пути сближения между ними. Продовольственный вопрос оставался актуальным, в связи с чем в Киев была отправлена специальная комиссия для проверки деятельности торговой палаты, во главе с А. Цвикевичем и М. Довнар-Запольским. Комиссия наделялась широкими полномочиями и, проведя реорганизацию работы палаты, предложила в декабре 1918 г. заключить торговое соглашение на равных правах с Украинским государством. Но дни правления Павла Скоропадского уже подходили к своему завершению.

Таким образом, на создание украинского консульского представительства в Минске влияло множество факторов: от беженского вопроса до геополитической угрозы. Деятельность украинских партий и общественных организаций на территории Белоруссии протекала в тесной связи с национальным движением в Украине. Это способствовало более активному объединению украинцев (беженцев и солдат) для защиты своих интересов в различных организация: радах, громадах. В условиях немецкой оккупации наиболее действенной становится работа консульского агентства. Инициатива украинских общественных организаций по открытию консульства в Минске способствовала открытию белорусского консульства в Киеве. Деятельность украинского консульского агентства была разнообразной, но в основном заключалась в решении беженского вопроса и налаживании торгово-экономических отношений между Белоруссией и Украиной.

\section{ИСТОЧНИКИ}

1. Вестник комитета Западного фронта. 1917. № 294 (450).

2. Вестник комитета Западного фронта. 1917. № 378 (534). 
3. Национальный архив Республики Беларусь (НАРБ). Фонд 325. Оп. 1. Д. 6.

4. НАРБ. Фонд 325. Оп. 1. Д. 19.

5. Українська Центральна Рада. Документи і матеріали у двох томах. Київ, 1997. Т. 2.

6. Центральный государственный архив высших органов власти Украины (ЦГАВО). Фонд 3766. Оп. 1. Д. 191.

7. ЦГАВО. Фонд 3766. Оп. 3. Д. 9.

8. НАРБ. Фонд 325. Оп. 1. Д. 8.

9. ЦГАВО. Фонд 3766. Оп. 3. Д. 33.

10. Ц ЦАВО. Фонд 3766. Оп. 1. Д. 68.

PhD Alexander Kuksa (Minsk, Belarus)

DIPLOMATIC RELATIONS OF THE BELARUSIAN PEOPLE'S REPUBLIC AND THE UKRAINIAN STATE (1918)

The article contains a detailed description of the Belarusian-Ukrainian political and diplomatic relations during the Ukrainian State in 1918. Although the Ukrainian State did not recognize the independence of the Belarusian People's Republic, but the Ukrainian consulate functioned in Minsk. The lack of unity of the bourgeois national states in the ruins of the Russian Empire led to the loss of their independence until 1920. Key-words: Belarusian People's Republic of Belarus, Belarus, Ukrainian State, Getman Pavel Skoropadsky.

доцент Александр Кукса (Минск, Беларусь)

ДИПЛОМАТИЧЕСКИЕ ОТНОШЕНИЯ БЕЛОРУССКОЙ НАРОДНОЙ РЕСПУБЛИКИ И ПРАВИТЕЛЬСТВА ПАВЛА СКОРОПАДСКОГО (1918)

Статья содержит подробное описание белорусско-украинских политических и дипломатических отношений в 1918 году. Хотя Украинское Государство не признавало независимости Белорусской Народной Республики, но украинское консульство функционировало в Минске. Отсутствие единства буржуазных национальных государств на руинах Российской империи привело к потере их независимости до 1920 года.

Ключевые слова: Белорусская Народная Республика, Беларусь, Украинская Держава, Гетман Павел Скоропадский.

доцент Олександр Кукса (Мінськ, Білорусь)

ДИПЛОМАТИЧНІ ВІДНОСИНИ БІЛОРУСЬКОЇ НАРОДНОЇ РЕСПУБЛІКИ ТА УРЯДУ ПАВЛА СКОРОПАДСЬКОГО (1918)

Стаття містить докладний опис білорусько-українських політичних і дипломатичних відносин в 1918 році. Хоча Українська Держава не визнавала незалежності Білоруської Народної Республіки, але українське консульство функціонувало в Мінську. Відсутність єдності буржуазних національних держав 
на руїнах Російської імперії призвела до втрати їхньої незалежності протягом 1919-1920 pp.

Ключові слова: Білоруська Народна Республіка, Білорусь, Українська Держава, Гетьман Павло Скоропадський.

* Кукса Александр Николаевич - кандидат исторических наук, доцент кафедры «Политология, социология и социальные учения» Белорусского национального технического университета. E-mail: akuksa@bntu.by. 
DOI 10.38129/ Ann.Yur.Ist.2019.3.1.2.65

УДК 340.132 .233

\title{
БОРЬБА ВИЗАНТИИ ЗА ПРАВО ВЛАДЕНИЯ ИТАЛИЕЙ: ИСТОРИКО-ЮРИДИЧЕСКАЯ ХАРАКТЕРИСТИКА ВОЙНЫ 541-552 ГГ.
}

\author{
ВИКТОР МЕЛЬНИК (Киев, Украина)*
}

Более четырех лет (535-540 гг.) понадобилось византийским войскам на установление полного контроля над Далмацией, Сицилией и большей частью Италии. В 537 г. была издана специальная новелла Юстиниана о переходе Сицилии под непосредственное управление имперских чиновников ${ }^{1}$. Эта новелла содержала нормы, характерные для многих новелл Юстиниана, изданных после републикации Кодекса (534). Вопервых, административные единицы Восточной Римской империи существенно расширялись. Теперь две провинции могли управляться лишь одним правительственным чиновником. Кроме того, произошла существенная унификация региональных форм самоуправления. Вводились новые полномочия для должностей претора, ректора и проконсула. Правители провинций были обязаны руководить как военными, так и гражданскими структурами. Этим шагом Юстиниан положил конец военно-административной структуре императора Диоклетиана (284-305), разработавшего систему полевых армий (comitatenses).

Восточная Римская империя возвращалась к тактике пограничной защиты (линия limes) и гарнизонного отпора (castellis) по всей линии границы. В первую очередь это касалось персидской и балканской границ. Увеличение числа славянских набегов, вместе с ожесточенными войнами на восточных азиатских территориях, вынудили Юстиниана осознать губительность применения только больших военных соединений. Славяне в 530-х гг. захватывали территории на Балканах, подобно германцам, прорвавшимся в Западную Римскую империю 31 декабря 406 г. (вандалы, бургунды, свевы). Поэтому Юстиниан решил вернуться к старой римской военной системе, испытанной в эпоху принципата (27 г. до н. э. - 284 г. н. э.) и модернизированной в контексте географического применения и политического значения.

${ }^{1}$ Nov. Just., 75; 104. 
Правители провинций обязаны были мобилизовать достаточные силы для обороны регионов и отвечали головой перед императором за варварские и персидские набеги. Перед ними стояла задача координировать действия с высшим командованием и оборонять каждый византийский населенный пункт. Кроме того, прокураторы должны были постоянно следить за сохранением достаточного уровня коммуникации между отдаленными частями вверенных регионов ${ }^{2}$. Что интересно, большое расширение полномочий совершенно не превращало региональных наместников в самовластных диктаторов. Юстиниану удалось наладить распределение постов так, чтобы сохранять перманентный контроль над каждым чиновником ${ }^{3}$. Юстиниан в своих новеллах прямо заявлял, что перед центральной властью стоит задача обезопасить коммуникацию внутри имперских регионов от различных проявлений сепаратизма и диктаторских притязаний наместников ${ }^{4}$.

Сицилию Велизарий подчинил непосредственной власти Юстиниана во второй половине 535 г. Но упомянутая законодательная новелла 537 г. ${ }^{5}$ не распространяла на Сицилии новый имперский административный порядок в полной мере. Новелла косвенно упоминала о создании административных условий, но, в силу сравнительной близости театра военных действий, разграничивала военную и гражданскую власть. Во главе гражданской власти на Сицилии становился претор, который вначале подчинился квестору священного дворца, а потом был переведен Юстинианом под управление префекта претория Италии (Фиделия, Репарата и пр.). В обязанности претора входил контроль над судебными и исполнительными органами, назначение чиновников, сбор и транспортировка налогов, инвентаризация имущества сицилийцев, учет и выплата жалования. При этом, претор Сицилии не имел права командовать военными. Полная юрисдикция (судебная, исполнительная и т. д.) над военными, находилась в руках дукса - dux Siciliae. Власть претора и дукса, таким образом, была полностью разделена, чего к 537 г. не наблюдалось на территориях главных провинций Восточной Римской империи - Малой Азии, Балкан, Ближнего Востока. 3. В. Удальцова отмечает, что похожие административно-правовые послабления действовали лишь только в

\footnotetext{
2 Именно нарушение коммуникации (информационного и культурного обмена, политической координации) привело к самоуничтожению институтов императорской власти на территории Западной Римской империи в V в.

${ }^{3}$ Об этом: Nov. Just., 24-26; 30; 39.

${ }^{4}$ Nov. Just., 25; 28; 30.

${ }^{5}$ Nov. Just., 75.
} 
Армении, «где была сильна местная знать и византийское правительство опасалось вводить строгую централизацию» ${ }^{6}$. 75-я новела Юстиниана подчеркивала права и свободы старой римской аристократии Сицилии. Помимо Сицилии и Армении, определенные локальные особенности административных отношений (хотя и неощутимые политически) сохранялись в Египте. И Сицилия, и Египет именовались в новеллах nostrum quodammodo peculium, то есть личным имуществом императора.

Итак, граница, проходившая вдоль реки По, позволяет утверждать, что практически весь Апеннинский полуостров в мае 540 г. оказался под фактическим контролем Восточной Римской империи. Лишь небольшая часть северной территории между Павией и Вероной осталась под властью разрозненных и разгромленных остготских военных формирований. Вслед за административной реформой на Сицилии, система власти на территории Апеннинского полуострова с 536 года также была разграничена. Если до 535 г., король остготов и наместник Италии (Теодорих Великий 8 493-526 г2., Аталарих в 526-534 г2., Амаласунта в 534-535 г2.) был лицом, в руках которого, волею византийского императора, сосредоточивалась $и$ гражданская, и военная власть, то после начала боевых действий летом 535 г. Империя взяла курс на дуализацию системы властных полномочий в Италии.

В 536 г. Юстиниан назначил Фиделия префектом претория Италии. Он должен был осуществлять всю гражданскую власть. Военные полномочия находились в руках командующего имперской армией Велизария. Такой порядок сохранялся все последующие годы византийского владычества в Италии (536-572 гг.). Институт должности префекта претория функционировал отдельно от должности командующего полевой армией.

Среди функций префекта претория Италии (в 539 г. им стал грек Афанасий), важнейшей обязанностью было распространение и опубликование старых и новых законов (leges) императора Юстиниана Великого. 3. В. Удальцова отмечает: «Новеллы Юстиниана, изданные между 537 и 540 гг., а также наиболее важные эдикты византийского правительства, обнародованные ранее, не только доводились до сведения жителей этих областей (о чем есть прямые упоминания в самих новеллах и в Прагматической санкции 554 г.), но и становились там действующим

6 Удальцова 3. В. Италия и Византия в VI веке. / 3. В. Удальцова. - М.: АН СССР, 1959. - c. 322. 
правом» 7 .

Интересно, что Прагматическая санкция говорит о давнем использовании византийского законодательства в Италии. В одиннадцатом пункте этого императорского документа сказано: «Сверх того мы постановляем, чтобы соблюдались право и законы, содержашиеся в нашем кодексе, которые мы уже давно послали в Италию в виде отдельных эдиктов» 8 . В данном контексте полезно вспомнить об указах Юстиниана Великого, издававшихся для Италии и западных римлян в 534-535 гг. Наверняка, существовали также более ранние распоряжения византийских императоров относительно полномочий и функций итальянских наместников. Это не вызывает никаких сомнений, если принять во внимание юридическую принадлежность позднеантичной Италии к Восточной Римской империи (после событий 476-480гг.). К моменту издания императором Юстинианом Прагматической санкции для Италии (554 г.), обозначавшей юридическое окончание второй итальянской кампании, Апеннинский полуостров де-юре находился под контролем Константинополя 74 года (480-554 гг.) 9

Предполагаем, что издание Эдикта Аталариха Амаласунтой в 534 г. являлось реакцией на общую законотворческую тенденцию в Восточной Римской империи. В любом случае, практическое введение кодифицированных норм римского права на итальянской территории, осуществлялось постепенно, поскольку Юстиниан существенно ослабил давление закона на рабов, которые больше не выполняли главные экономические функции. Теперь первую скрипку в социальноэкономическом оркестре Империи играли колоны - полузависимые крестьяне, юридически прикрепленные к определенному земельному наделу. На Сицилии и значительной части Италии, в отличие от Малой Азии и Балкан, значение рабского труда оставалось высоким. Армения, Египет и Сицилия оставались рабовладельческими провинциями, что

7 Удальцьова 3. В. Там же. - с. 323.

8 Pragm. Sanc., 11. Перевод 3. В. Удальцовой: Удальцова 3. В. Там же. - с. 323. Курсив наш!

9 О широком распространении норм кодифицированного римского права в Италии (536-540 гг.) см. в законодательных новеллах того времени: Nov. Just., 69; 70; 73; 75; 80; 89; 91; 101; 104; 106. Интересен спор о хронологии окончательного распространения всех норм Дигест, Институций и Кодекса на итальянскую провинцию. В любом случае, не вызывает сомнений полноценное использование итальянцами систематизированного Юстинианом законодательства. Об этом детально в: Удальцова 3. В. Там же. - с. 323, особенно - с. 323, прим. 5! 
вынуждало Юстиниана идти на определенные административные хитрости. Разделение гражданской и военной властей являлось одной из таких хитростей. Также Юстиниан не назначал греков в первые годы войны на важнейшие гражданские должности (хотя греки полностью руководили военными подразделениями). В случае с префектами претория Фиделием и Репаратом, Юстиниан вел политическую игру с итальянскими рабовладельцами-аристократами, благодаря чему снискал еще большую поддержку зажиточных апеннинских провинциалов. Назначение грека Афанасия префектом претория в 539 г. прервало сложившуюся было традицию и гражданская администрация постепенно подчинилась выходцам из Нового Рима - Константинополя. В данном случае Юстиниан вел себя политически верно и занимался окончательной ликвидацией последствий итальянского сепаратизма, подогревавшегося самостоятельной внутренней политикой остготских королей-наместников.

Впрочем, майское соглашение 540 г., прекратившее период остготского владычества в Италии, не остановило разрастания германских амбиций. Ряды воинственных остготских земледельцев, живших в северных горных районах Италии, были пополнены изгнанными из Равенны воинами ${ }^{10}$. В городе Павия (Тичин), в июне 540 г. собрался большой военный совет oстготов 11 . Германцы решили избрать вождя по старому обычаю - на тот момент представители королевского рода Амалов либо погибли, либо перешли на сторону Восточной Римской империи. На этом совете собравшиеся остготы заявили, что «опасности войны они предпочитают состоянию рабства».

Сначала титул вождя предложили руководителю миланской группировки остготов Урайе, но тот отказался в пользу племянника вестготского короля Теудиса - Ильдибада (540-541) 12.

Как мы помним, вестгот Теудис был представителем чиновнической номенклатуры времен Теодориха Великого (493-526). Происходя из знатного остготского рода Паннонии, он длительное время являлся оруженосцем самого Теодориха. Именно Теудис «опекал» внука Теодориха Амалариха и контролировал испанские дела. Когда дело приближалось к распаду государства Теодориха, Теудис совершил первый и главный шаг организовал коронацию Амалариха вестготским королем. Сразу же после

\footnotetext{
10 Procop. BG, II.30.3; Iord. Rom., 378.

11 Procop. BG, II.30.3-5.

12 Procop. BG, II.30.14-16.
} 
смерти Амалариха13, Теудис занял его престол, будучи политическим основателем Толедского королевства вестготов ${ }^{14}$. Поражение вестготов в 507 г. от франков и бургундов, потеря своей главной территории (Аквитании) и длительное подчинение Равенне (511-526 гг.) значительно ограничили вестготские силы, но правление Теудиса (531-548) подняло боевой дух вестготов и создало надежды на восстановление политического могущества старой Вестготии. Вполне очевидно, что Теудис был главным лоббистом возвышения Ильдибада. Теперь, после многих лет подчинения вестготов остготам, все могло перевернуться наоборот. Известно, что Теудис был человеком амбициозным и честолюбивым. Объединив усилия с остатками остготов (самыми воинственными остатками!) Теудис мог предпринять попытку реставрации могущественного королевства Теодориха Великого. Вот только первенство в реставрированном королевстве должны были получить вестготы, а не остготы. Кроме того, в территориальном контексте, Теудиса, по понятным причинам, больше интересовали Аквитания и Южная Галлия, утраченные готами под нажимом франков.

По сообщению комита Марцеллина (Marcellinus Comes), Ильдибад был избран остготским рексом - королем, но реальная власть в североитальянской Остготии осуществлялась им вместе с генералом Урайей ${ }^{15}$. Считаем вполне реальной гипотезу о том, что Урайя мог быть приставлен остготской знатью к продвигаемому Теудисом (531-548) кандидату Ильдибаду ради обеспечения внешнеполитической безопасности. Впрочем, как отмечал Прокопий, если Урайя вел роскошный (по остготским меркам) образ жизни, то Ильдибад «жил бедно, не прикасаясь к королевским деньгам»16. Вызывая своим сдержанным поведением общественное одобрение и обладая только одной тысячей воинов, Ильдибад начал восстановление остготской власти над северной Италией. Сначала он принялся за наведение порядка среди самих остготов. Разрозненные и зараженные анархией отряды вынуждались к подчинению ${ }^{17}$.

После боя под Тревизо, когда Ильдибаду удалось разбить иллирийские и герульские части византийского полководца Виталия,

13 Амаларих пробыл вестготским королем всего 5 лет - с 526 по 531 гг. Его убили на юге Галлии франкские солдаты во время грабительского набега на вестготскую провинцию Нарбонну.

14 Теудис правил Испанской Вестготией с 531 по 548 гг.

15 Marc. Chron., a. 540.

16 Procop. BG, III.1.39.

17 Procop. BG, III.1.27. 
остготы окончательно возвратили под свой контроль регионы Лигурии и Венеции. Иордан и Прокопий отмечали, что победа под Тревизо принесла новому королю большую славу ${ }^{18}$. Сплочение разрозненных сил остготов вокруг фигуры вестготского ставленника Ильдибада раздражало многих представителей остготской знати. В первую очередь, сожалел о собственном отказе от короны Урайя. Конфликт с Ильдибадом был неизбежен и вскоре Урайя был убит ${ }^{19}$. Но не вызывает сомнений, что круг противников Ильдибада оказался слишком широким, а политический вес короля слишком маленьким для противостояния старой остготской военной знати. В мае 541 года король Ильдибад погиб от меча собственного телохранителя Веласа 20.

Ликвидация Ильдибада вновь внесла раздор в остготские общины. Кроме того, она нивелировала возможное военное сотрудничество с вестготами. Внутри остготских общин возросло влияние других германских племен, сражавшихся когда-то вместе с остготами в Паннонии и Далмации 21 . Племя ругов сумело протолкнуть на властные вершины своего ставленника - Эрариха, ставшего королем остготов после смерти Ильдибада ${ }^{22}$.

Североитальянское наступление Ильдибада (540-541) пришлось непосредственно на времена отражения персидской угрозы Юстинианом Великим в Месопотамии и Сирии. Усилия всех имперских чиновников Константинополя были обращены к Антиохии и заключению мирного договора. В связи с этим Юстиниан даже отменил триумфальное чествование победителя остготов Велизария (540), которое должно было состоятся по древнему римскому обычаю.

Учитывая гениальные административные и юридические таланты Юстиниана, удивительным кажется тот факт, что византийские войска Италии, после немедленного перевода Велизария на персидский фронт (540 г.), перешли под совместное управление трех полководцев. Генералы Бесса, Иоанн и Константин постоянно ссорились друг с другом, что негативно сказывалось на организации управленческой системы в регионе. Военная администрация византийцев дублировала полномочия местных органов власти. К слову, бюрократов всегда хватало в Италии. Особый расцвет апеннинской бюрократии начался со времен установления

18 Procop. BG, III.1.34-36; Iord. Rom., 378.

19 Procop. BG, III.1.37-42.

20 Procop. BG, III.1.43-49.

21 Procop. BG, III.2.5.

22 Procop. BG, III.2.1-4. 
Диоклетианом (284-305) политического режима домината (dominatus). Римские сенаторы-рабовладельцы не желали делиться своей властью с греческими эмиссарами. Большое значение, на наш взгляд, имели также социальные различия b процессе экономического производства. Если для греков нормой было преимущественное использование колонов, то в Италии оставался прежним жесткий режим рабовладения. Поддающееся мощному моральноэтическому влиянию христианства, римское право пыталось сгладить отношения между господами и рабами, но длительное управление остготов-ариан серьезно затруднило процесс перехода Италии на уровень преимущественного использования труда полузависимых и полностью независимых крестьян.

В аристократических усадьбах римлян периода остготского владычества, произошла определенная консервация обычаев. (Не в последнюю очередь, из-за слабой торгово-экономической коммуникации между Италией и Элладой в 468-535гг.)23. И теперь, когда перед присланными вместе с префектом претория Афанасием византийскими чиновниками, была поставлена задача восстановить и укрепить итальянскую экономику (ради создания здесь мощной налоговой базы Империи), в открытой оппозиции к чиновникам оказались многие сенаторы и аристократы. Получалось так: остготские короли раньше не вмешивались во взаимоотношения аристократов и зависимого от них населения, тогда как византийский император начал проводить социально-экономические преобразования. И хотя цель этих преобразований состояла в укреплении налогового потенциала Италии, косвенно они направлялись в сторону изменения социального фундамента производства. Возникли первые внутренние трения между чиновниками Константинополя и аристократами Италии.

Впрочем, трения подобного рода, в условиях трансформации социально-экономической системы (и, соответственно, культурной ломки мировоззрения) могли возникнуть (и постоянно возникали) в любой другой провинции. Их нельзя возводить в ранг фундаментального

23 В 468 г. армия византийского императора Льва I Великого (457-474), руководимая шурином императора Василиском, потерпела сокрушительное поражение от вандало-аланского войска короля Гензериха (428-477). Решающая схватка под Карфагеном лишила Италию и всю Западную Римскую империю контроля над морскими путями сообщений в Средиземноморье, а Византии пришлось оборонять уже собственный Эгейский бассейн. Данное событие вызвало политическое падение Западной Римской империи в 476-480 гг. и привело к остановке полноценной средиземноморской торговли. 
«цивилизационного» противоречия греков (условного «Востока») и римлян (условного «Запада»). Необходимо особо подчеркнуть: идеологических противостояний между итальянцами и греками в то время не существовало вообще. Некоторые признаки политического недовольства выросли из возвышения центральной администрации. Упомянутая же тройка полководцев (Бесса, Иоанн и Константин) назначала на все ключевые посты выходцев из Константинополя. Уже к началу 541 г. такой подход начал вызывать политическое недовольство, подогреваемое прямой зависимостью крестьян от сенаторов-аристократов. Недовольными на самом деле были представители высших слоев общества, принимавшие все возможные меры для запугивания византийских чиновников (в том числе, путем воздействия на подконтрольные народные массы). Итальянская аристократия впервые за много лет почувствовала возможность не политического, но экономического притеснения своих прав. Это следует связывать с фискальной политикой новых греческих чиновников. Именно налоговое законодательство Юстиниана (административная централизация, пропаганда христианских принципов взаимоотношений в производстве, попытка создания налоговой базы при раздельном функционировании военных и гражданских структур) сыграло злую шутку, сведя в итоге на нет все достижения первой итальянской кампании Велизария (535-540).

Так как исторический процесс представляет собою неразрывную связь причин и следствий, то любое рассматриваемое нами событие одновременно есть результатом предыдущего события и началом последующего. Вполне закономерно, что так случилось и с практикой сбора налогов византийскими логофетами геникона (налоговыми чиновниками). Юстиниан Великий, занимаясь кодификацией римского законодательства, руководствовался той огромной пользой, которую эта кодификация принесет для государственного устройства будущей единой империи, включающей провинции Востока и Запада. Помимо христианской религиозности и административной централизации, которые Юстиниан пытался учреждать по всей территории Византийской империи, существовал также и человеческий фактор - тот самый фактор исторического процесса, который погубил Урайю и Ильдибада на севере Италии. Ведь организация создания налоговых баз была устроена таким образом, что логофеты геникона получали заработную плату из государственной казны лишь согласно результату исполненной работы. Чем большая сумма собранных налогов указывалась логофетом геникона в отчетной документации, тем больше жалования ему выплачивал император. Находясь вдали от Константинополя, налоговики, работая в 
тесной связи с военной и гражданской администрацией, осознавали, что в виду военного положения на Апеннинском полуострове, шансов быть привлеченными по судебному обвинению у них намного меньше. Сформировался феномен, который вполне можно назвать «налоговым фронтом» итальянских военных кампаний Юстиниана. Опустошенные четырехлетними боевыми действиями территории опустошались вдобавок налоговыми чиновниками, которые усердно старались ради повышенного жалования. Особенно серьезно повлияло на рост всевозможных налогов византийско-персидский перемирие. И хотя бремя выплаты огромных сумм дани для персидского императора лежало на всех гражданах империи, для жителей Италии, всячески подстрекаемых недовольными сенаторами и землевладельцами, ломка старых порядков и создание новых казались неприемлемыми. Преследуя исключительно личные интересы, желая обогащаться всем чем только возможно, социальная верхушка Италии, сама не осознавая возможных политических последствий, разжигала антигреческие настроения.

Наследник Ильдибада Эрарих, происходивший из знатного рода племени ругов осевших на землях современной Венетии, правил остготами всего пять месяцев. Его убили в том же году (осенью 541 г.) 24. Однако, фигура краткосрочного правителя интересна для нас другими фактами.

Остготский король Эрарих был коронован ориентировочно в маеиюне 541 г. В то же время он выслал германское посольство в Константинополь, официально предложив Юстиниану признание существующих границ со стороны остготов. Последние должны были оставаться в пределах территорий за рекою По. При этом, речь шла об окончательном признании юридического верховенства восточного императора, но Остготское королевство должно было получить больще внутренней политической самостоятельности. Вполне возможно, что Эрарих ожидал военной помощи со стороны византийцев для укрепления собственной власти.

Основания для такого предложения у Эрариха были весомые. Война против итальянского контингента византийцев уже активизировалась и нарастала с каждым днем. Византийские пограничные заставы на реке По постепенно переходили к оборонительным военным мероприятиям. Мобилизованные королями Ильдибадом (540-541) и Эрарихом (541) отряды предпринимали постоянные набеги на укрепленные линии византийцев. Очень может быть, что военные нападения на императорские силы, в тот

\footnotetext{
${ }^{24}$ Procop. BG, III.2.18.
} 
момент, воспринимались остготами не как возможность нанести византийцам поражение, но как реальная возможность вынудить императора помочь остготам в деле обустройства собственного королевства на Севере Италии. Этот тезис вполне подтверждает сообщение Прокопия, что Эрарих тайно предлагал Юстиниану передать Империи всю Северную Италию, за что он просил большую сумму денег и титул патриция 25 . Прокопий прямо указывает на то, что остготы подняли мятеж, узнав о тайных переговорах Эрариха с Восточной Римской империей.

Посольская миссия короля Эрариха (541) и возможность мирного установления византийского политического контроля над Северной Италией провалились не только из-за смерти самого Эрариха... В начале 542 г. Юстиниан заболел бубонной чумой. Эпидемия распространилась на большие территории, а Константинополь превратился в ее эпицентр. Уровень смертности был очень высокий. Император несколько месяцев находился без сознания. Его выхаживала лично императрица Феодора. Несмотря на все негативные прогнозы константинопольских врачей, Юстиниан выздоровел к середине 543 г. Это время болезни императора стало решающим для той кампании, которую мы назовем bmорой итальянской войной (541-552).

Осенью 541 г. королем остготов стал племянник Ильдибада - Тотила (541-552). Тотила организовал убийство Эрариха, хотя незадолго до этого лично вел переговоры с византийцами о передаче им крепости Тревизо 26. Иордан отмечал, что в момент избрания Тотилы королем, ему не исполнилось даже тридцати лет ${ }^{27}$. Комит Марцеллин в описании 542 года говорит о том, что предоставление остготами Тотиле королевской власти стало невероятным бедствием для Италии ${ }^{28}$. Так или иначе, но Тотила является одним из немногих варварских королей, который благодаря военному конфликту с великой Империей и соответственному вниманию источников, превратился в яркий и характерный образ позднеантичной/раннесредневековой эпохи. Большинство историков и биографов благоволят Тотиле и относятся к нему как к борцу за освобождение Италии и за политическую институционализацию остготов. Он был воином, но борцом не был. Нужно учитывать, что Тотила воевал не за Италию, а против Италии. Ведь Тотила противостоял Империи,

\footnotetext{
25 Procop. BG, III.2.15-18.

${ }^{26}$ Marc. Chron., a. 542.

27 Iord. Rom., 379.

${ }^{28}$ Marc. Chron., a. 542.
} 
органической и законной частью которой Италия являлась всегда. При этом, Тотила явно пытался завоевать эту провинцию, отторгнуть ее от Империи (чего не сделал и никогда не пытался сделать Теодорих Великий).

Тотила искусно пользовался недовольством многих римских аристократов византийской налоговой политикой, привлекал на свою сторону разагитированные общественные низы. Интересным феноменом являлось широкое привлечение Тотилой на свою сторону итальянских рабов, что послужило причиной положительного восприятия Тотилы даже советской историографией. Его фигура удивительным образом сплотила в похожих позитивных оценках и ярких красках немецких историков-националистов, историков-германистов всего мира, итальянских, англосаксонских ученых и даже советских ученых-марксистов. Если Юстиниан открыто именуется «истинным антигероем» 29 , то Тотила называется «отважным героем» 30 .

Для советской марксистской историографии характерно приписывание Тотиле определенной социальной направленности ${ }^{31}$. Безусловно, что классовая политика Тотилы была революционна для поздней античности (в этом мы полностью соглашаемся с 3. В. Удальцовой). Но, понимая ход исторических событий, учитывая реальную и законную принадлежность Италии к сфере влияния и административного контроля Византии, тяжело разделить проготскую позицию ученой. Вот как характеризует начало второй итальянской войны сама Удальцова: «В своей борьбе с империей остготская знать стремилась вернуть потерянные земли и богатства. Она не желала уступить римским рабовладельцам, вновь начинавшим хозяйничать в Италии, свои земельные владения, не хотела терять власть и влияние. Но в тоже время большая часть остготской знати не желала также и идти на серьезные уступки народным массам... Только страшное поражение, во многом обусловленное предательством самой же остготской знати, а также отсутствие поддержки со стороны народных масс Италии, заставило уцелевших вождей остготов серьезно призадуматься над дальнейшими судьбами своего племени. Сама логика борьбы с рабовладельческой империей, вновь протянувшей свои щупальцы к Италии, вынудила наиболее дальновидных из них пойти, как мы увидим

29 Хизер Питер. Восстановление Римской империи. Реформаторы Церкви и претенденты на власть. / Питер Хизер. - М.: Центрполиграф, 2015. - с. 144.

30 Балух В. О. Візантиністика. Курс лекцій. / В. О. Балух. - Чернівці: Книги-XXI, 2006. - c. 86.

31 Ознакомившись с классической работой 3. В. Удальцовой, короля Тотилу неразборчивый читатель может счесть если не за социалиста, то, по крайней мере, за продолжателя дел Спартака. 
дальше, на временный союз с народными массами в расчете использовать в своих интересах широкое народное движение, развернувшееся вскоре в Италии. И наиболее талантливым вождем остготов, проводившим подобную политику, оказался Тотила. Именно он решительнее, чем другие, стремился обеспечить готам поддержку со стороны самых широких слоев населения Италии, и в этом секрет его успехов в борьбе с Византией. Но в этом же и причина ненависти к нему со стороны известной части знати»32.

Во-первых, остготская знать действительно боролась за возврат доходов и земель, за восстановление своего привилегированного положения на всей территории Италии (включая Далмацию и Сицилию). Но ведь римские «рабовладельцы» не «вновь начинали хозяйничать в Италии». Римские рабовладельцы более прибыльно и успешно хозяйничали в Италии во времена остготского владычества. Пятьдесят пять лет римские рабовладельцы, признавая юридическое верховенство императора, занимались политической кооперацией с германской верхушкой вообще и остготской верхушкой в частности. Римские рабовладельцы получили от остготов полную свободу действий - в том числе относительно эксплуатации рабов. Соответственно, римские рабовладельцы еще хуже «хозяйничали» в Италии на протяжении всего периода правления остготов, чем это было до того, во времена западноримских императоров эпохи домината.

Во-вторых, «логика борьбы остготов с рабовладельческой империей» не совсем адекватна канве исторических событий. Остготы сами участвовали в работорговле и никоим образом не могли выйти за рамки экономической системы поздней античности (или даже раннего средневековья). Мировоззрение остготов, как и любых других варваров, являлось полностью рабовладельческим. Никакого благосклонного отношения к рабам или зависимым людям, на протяжении сорокатрехлетнего правления остготов (493-536 гг.), в Италии не наблюдалось. Римские рабовладельцы полностью контролировали свои земли и рабов, а остготы подчинялись «рабовладельческой империи», называя себя верноподданными восточноримского императора ${ }^{33}$. Зачем рабовладельцам-остготам вообще было социально-экономически бороться с рабовладельческой империей? Тем более, после того как Империя санкционировала переход Италии под власть остготов (в 488 г.)! Остготы и византийцы были едиными во всех своих интересах на протяжении

\footnotetext{
32 Удальцова 3. В. Там же. - с. 336.

33 Iord. Get., 304.
} 
длительного времени. Юридический контроль Византии над Италией подтверждает это.

В-третьих, утверждение Удальцовой о том, что Византия «вновь протянула свои щупальцы к Италии» ${ }^{34}$ не соответствует ходу исторических событий. Ведь сама 3. В. Удальцова обработала огромное количество материала, посвященного различным аспектам политико-юридической жизни остготской Италии... Ход истории и правовой материал позволяют сделать вывод о том, что с 480 г. Италия являлась подчиненной Византии территорией ${ }^{35}$. И Одоакр, и Теодорих, и Аталарих, и Амаласунта 36 были наместниками Восточной Римской империи ${ }^{37}$. Все имели разные политические отношения с Империей, но все принимали и признавали верховную власть императора. Как же могло произойти «протягивание щупалец» к Италии, если Италия была де-юре зависимой от Константинополя территорией? Кроме того, убийство Теодатом при поддержке остготской знати законной королевы-наместницы Амаласунты (535 г.) не добавляет сопротивлению остготов законности. То же самое очевидно и в отношении Матасунты (внучки Теодориха Великого), которая открыто выступала за Византийскую империю. То, что весь королевский род Амалов поддерживал византийцев позволяет утверждать, что германистический взгляд на остготско-византийские войны (присущий даже ведущим советским и современным отечественным специалистам) необходимо коренным образом пересмотреть.

34 Удальцова 3. В. Там же. - с. 336.

35 См. нашу попытку обощения этого тезиса: Мельник В. М. Римская империя в V веке. Крушение или перерождение? // Наука и техника. Июль, 2019. №7 (158). С. 60-66.

36 О королеве Амаласунте, как «стороннице» императора Юстиниана писал и Георгий Курбатов. См.: Курбатов Г. Л. Ранневизантийские портреты: К истории общественно-политической мысли. Ленинград: Издательство Ленинградского университета, 1991. С. 253. Для понимания юридической зависимости германских королей Италии от власти и персоны императора Восточной Римской империи полезна вся седьмая глава этой книги: Курбатов Г. Л. Там же. С. 221-266.

37 Ведущий украинский историк Василий Балух об этом пишет: «В 477 г. Одоакр формально подчинился константинопольскому императору и правил как назначенный Зеноном патриций и военачальник, хотя на самом деле стал первым германским военным правителем Империи. Итак, падение Западной империи внешне выглядело как восстановление единства всего государства, изентр которого окончательно переместился на Восток». - Балух В. О. Історія античної цивілізації у трьох томах. Том 2: Стародавній Рим. Чернівці: Наші книги, 2016. С. 686. 
Король Тотила (541-552) действительно был незаурядной личностью, талантливым военным вождем и политиком. В истории готов (и остготов, и вестготов вместе) его личность должна занимать вторую позицию после Теодориха Великого. Заметим однако, что обеспечение «широкой поддержки народных масс» для начинаний Тотилы было бы невозможно, если бы не подстрекательство со стороны многих представителей римскоитальянской элиты и если бы не затяжная болезнь Юстиниана Великого, осложненная необходимостью решать персидскую проблему на восточной границе ${ }^{38}$. Грубо говоря, Юстиниан на некоторое время отвернулся от западных провинций, что было явной ошибкой.

Тотила начал активные боевые действия в 542 г., разбив византийцев под Вероной. Далее следовали победы возле Фаэнцы и уничтожение армии полководца Иоанна в окрестностях Флоренции (весна 542 г.). Победа возле Муджелло позволила Тотиле привлечь на свою сторону большое количество пленных византийцев ${ }^{39}$. Весна-лето 542 года были наиболее страшными для византийской армии. Количество готского войска многократно усилилось за счет итальянского плебса и многочисленных дезертиров из разваливающихся императорских подразделений. Зинаида Удальцова отмечает: «Весть о полном поражении столь прославленного полководца, как Иоанн, навела панический страх на византийских командиров, которые теперь совершенно отказались от наступательных действий против Тотилы и вся их деятельность сводилась лишь к укреплению занятых ими крепостей» ${ }^{40}$.

Летом 542 г. разросшаяся армия Тотилы вступила в Цезену, Урбин, Монс Феретр, Петру Пертузу. Переход Апеннин обеспечил остготов доступом к огромным запасам хлеба, сосредоточенным византийцами в провинции Тусция ${ }^{41}$. Прокопий Кесарийский отчетливо свидетельствует, что войска Тотилы встречали сопротивление у стен городов, но легко завоевывали сельские местности. К началу 543 г. король Тотила захватил Южную Италию Бруттий, Апулию, Луканию, Калабрию. В этих регионах проживало множество этнических греков и эллинизированных итальянцев. Они поддались на искусно организованную пропаганду остготов. Как отмечает Прокопий, Тотила приказал своим подчиненным относится к римлянам мягко. В остготской армии часто встречались случаи казни за плохое

\footnotetext{
38 Курбатов Г. Л. Там же. С. 253-254.

39 Procop. BG, III.5.19.

40 Удальиова 3. В. Там же. - с. 339.

${ }^{41}$ Iord. Rom., 379.
} 
отношение к римскому населению (и даже к военнопленным!) ${ }^{42}$. Его армия на первых порах проявила «так много человечности, что этого нельзя было ожидать ни со стороны врага, ни со стороны варвара»43. Вскоре византийцы вообще и греки в частности составляли порядочную долю войска Тотилы.

Тотила был видным политическим технологом. Его политический талант, хотя и проявлялся в решениях меньшего масштаба, был очень близок к административному гению императора Юстиниана. Византийская кодификация римского права не принесла Константинополю психологического перевеса во второй итальянской войне (541-552 гг.), хотя, безусловно, влияла на ход событий первой кампании (536-540 гг.), будучи важнейшей составной частью «римской идеи». Однако в 541-543 гг. итальянцы почувствовали пресс имперской налоговой бюрократии и полный развал военной администрации. Большой бедой стали отряды византийских дезертиров. Тотила организовывал пропаганду, используя огромную и хорошо подготовленную сеть агитаторов. В Риме и Неаполе распространялись прокламации Тотилы, воздействовавшие на более образованные слои населения ${ }^{44}$. Константинополь явно терял контроль над ситуацией.

В «Диалогах»45 Папы Римского Григория I Великого (590-604) описывается популистский и демагогический подход Тотилы, который ни перед чем не останавливался в процессе обретения или осуществления власти. Папа Григорий чаще всего акцентировал на притеснениях ортодоксальных священников со стороны остготов. Именно в этих притеснениях папа видел реальную сущность внутренней политики остготского короля. Фактически, возврат многих итальянских территорий под контроль германцев означал установление новой и более жесткой еретической диктатуры ариан ${ }^{46}$.

В 543 г. перед Тотилой стояла задача привлечения широких итальянских масс на сторону остготов. Это было связано с завоеванием Южной Италии, которая, как известно, наиболее симпатизировала

42 Procop. BG, III.6.4; 8.12-25; 8.1.

43 Procop. BG, III.8.1.

44 Попытка охарактеризовать социально-экономическую политику Тотилы: Удальцјова 3. В. Там же. - с. 340-353; Леъченко М. В. История Византии. / М. В. Левченко. - М.-Л., 1940. - с. 81-83.

45 В православной церковно-историографической традиции чаще употребляется неверный перевод «Двоеслов», который, однако, отражает философскую задумку трактата Папы Григория.

46 Greg. I. Dial., I.2; II.15, 31; III.11, 13, 18. 
Византии и являлась главным поставщиком продовольствия для всего Апеннинского полуострова. В этом направлении король Тотила сделал важный и умелый политический шаг - уменьшил налогообложение для больших землевладений и фактически объявил о неприкосновенности всей сотрудничавшей с Константинополем сенаторской аристократии ${ }^{47}$. При этом, обеспечение безопасности сенаторов и сохранение их главных доходов перекрывалось огромными конфискациями церковного имущества.

Получалось так: остготы грабили церкви и разоряли монастыри, а римские сенаторы спокойно смотрели на бесчинства ариан и тихо поддерживали их победное шествие, изменяя религии ради налоговых льгот. К примеру, папа Григорий (590-604) писал в «Диалогах», что остготы ограбили Фунденский монастырь в провинции Самний, что, к его удивлению, не вызвало никаких неудовольствий со стороны местных аристократов ${ }^{48}$. Здесь считаем необходимым подчеркнуть, что именно начальные успехи Тотилы и безнаказанный захват Южной Италии привели впоследствии к организации масштабных гонений на сенаторскую аристократию. В итоге, воспользовавшись общественным недовольством высоким византийским налогообложением, захватив большую часть Италии, остготы начали повальную конфискацию имущества поддерживавших их до этого римлян. Описывая нормы Прагматической санкции Юстиниана Великого (554г.) ${ }^{49}$, возвращавшей конфискованные землевладения итальянским церковникам и аристократам, Зинаида Удальцова подчеркнула: «Захваты и конфискация не уничтожили тогда полностью крупное землевладение, но нанесли ему очень тяжелый удар, от которого оно так и не смогло полностью оправиться, несмотря на все предписания Прагматической санкции и других законодательных актов Юстиниана, целиком направленных на реставрацию этой формы земельной собственности» 50 .

В конце 542 г. Юстиниан назначил полководца Максимина одновременно префектом претория и главнокомандующим Италии. Это означало, что Константинополь принимает меры к распространению на Италию общеимперской формы административной власти. В некотором смысле, назначение Максимина было шагом к административной

47 Procop. BG, III.6.5; 13.1.

48 Greg. I. Dial., I.2. Факты притеснений и разорений ортодоксальной Церкви со стороны еретиков-ариан: Greg. I. Dial., II.14, 15, 51.

$49 \mathrm{O}$ «Прагматической санкции» 554 года см.: Курбатов Г. Л. Там же. С. 254.

50 Удальцова 3. В. Там же. - с. 347. 
вертикали, существовавшей при Теодорихе Великом (493-526), Аталарихе (526-534) и Амаласунте (534-535). Вся военная и гражданская власть теперь концентрировалась в руках одного человека, который всецело отвечал перед императором Юстинианом. Для подкрепления префекта Максимина Юстиниан также выслал в Италию небольшие, но боеспособные воинские подразделения армян, гуннов и фракийцев ${ }^{51}$. Вполне возможно, что среди гуннов и фракийцев присутствовало какое-то количество славян. В любом случае необходимо помнить о присутствии славянского элемента на протяжении всей византийско-остготской войны. Еще в 537 г. славянскоантское подкрепление присылалось Юстинианом на помощь Риму, осажденному остготским королем Витигисом ${ }^{52}$.

Впрочем, Максимин, хотя и сосредоточил в своих руках полноту власти, не смог правильно ею распорядиться53. Гораздо больше надежд византийские солдаты возлагали на соратника Велизария - полководца Димитрия. Крупное поражение Димитрия от арьергарда Тотилы под Неаполем (пребывавшем в остготской осаде) сломило боевой дух армии. После следующего поражения Димитрий был взят в плен и принужден с веревкой на шее стоять перед воротами Неаполя и просить жителей города капитулировать перед войсками «великого Тотилы» 54 . Остготский король лично обещал Неаполю мир, в случае добровольной сдачи. Он заявил жителям Неаполя, что считает себя истинным королем готов и италийцев, и отдаст приказ щадить последних в этой войне. Византийскому гарнизону остготы гарантировали сохранение имущества и жизни. Прокопий сообщает, что жители Неаполя поддались обещаниям Тотилы и тот их полностью сдержал. Весной 543 г. город перешел под контроль остготов, а весь восточноримский гарнизон Тотила отправил в Рим, предварительно снабдив византийцев продовольствием. Это стало наверное самой крупной политической рекламой для короля, сослужившей ему прекрасную службу на протяжении дальнейших восьми лет. Впрочем, Тотила, помня об ошибках Витигиса (536-540) в первую итальянскую кампанию, на этот раз предпринимал все шаги для «обесточивания» военной энергии

51 Procop. BG, III.6.9-10.

52 Считаем верным предположение о славянском характере «гуннов», упомянутых в трактатах Прокопия. Сами гунны были уничтожены германцами и славянами еще в 450-х гг. Их название, как и этнонимы «скифы» / «сарматы», автоматически закрепилось за оставшимся населением Восточной Европы. Среди этого населения преобладали германцы и славяне.

53 Procop. BG, III.6.12-13; 7.1-3.

54 Procop. BG, III.7.8-9. 
византийцев. В частности, при захвате итальянских городов Тотила занимался уничтожением укреплений, чтобы избежать возможного возврата городов под византийский контроль и дальнейшей осадной войны. Вся его тактика базировалась на сражениях в открытом поле, где остготы могли продемонстрировать напор и бесстрашие. Остготы намного хуже воевали в осадных и оборонных условиях.

В 543-544 гг. Тотила укреплял власть на южных территориях. Центральная Италия практически полностью покорилась. Вокруг Вечного города сжималось новое кольцо. Разгром византийского флота под Неполем позволил Тотиле приступить к созданию остготского флота. Основой военно-морских сил были захваченные неапольском бою корабли. При этом, флотские и сухопутные соединения остготов пополнялись огромным количеством рабов и зависимых крестьян, рекрутацию которых Тотила поощрял на землях Центральной Италии.

Весной 544 г. остготами была захвачена Калабрия. Под контролем византийцев оставался только важнейший порт Гидрунт (теперь Отранто)55. Прокопий пишет, что к началу 544 г. «византийские начальники в укреплениях пировали вместе со своими возлюбленными, а солдаты, проявляя крайнее неповиновение начальникам, предавались всяким безобразиям»56. Моральное разложение многих восточноримских соединений было выгодно для Тотилы, демонстрируя контраст между его собственными «гуманностью и дружелюбием» и византийской «алчностью и беспечностью».

Тотила показательно наводил порядок в войсках, предавая смертной казни всех дизертиров и мародеров. Уловив момент, Тотила начал притеснять земельных аристократов, получая взамен поддержку широких слоев зависимого и полузависимого крестьянства. Здесь он и черпал силы для пополнения собственной армии. Римские землевладельцы очень сильно просчитались, поставив на Тотилу. Он воспользовался их неудовольствием оплаты больших налогов и начал, в итоге, собственную социальную политику. Аристократы попали в немилость как византийцев, так и остготов. Чем больше территорий переходило под контроль Тотилы, тем меньше он сдерживал собственных солдат в их желании мстить сенаторам бывшим хозяевам. В итоге, аристократические землевладения грабили намного чаще и жестче, нежели взятые штурмом города. Комит Марцеллин, например, сообщает, что в крепостях Фирм и Аскул остготы

\footnotetext{
55 Procop. BG, III.9.4.

56 Procop. BG, III.9.1.
} 
пощадили всех византийских солдат, сохранив им имущество, свободу и военную амуницию, но перебили почти всех местных жителей ${ }^{57}$.

В конце 545 г. Тотила приступил к осаде Рима.

Уже длительное время кольцо вокруг Вечного города сжималось и теперь, полностью завоевав Центральную Италию, Тотила мог себе позволить совершить важный символический шаг. Известно, что Тотила писал письма для римского сената, обещая полное прощение византийских симпатий в том случае, если сенаторы осознают единство и неразрывную связь политических интересов германцев и римлян на территории Италии.

В первом послании к сенаторам Тотила объявил о сплошной неблагодарности римских аристократов, которые получили от Теодориха и Амаласунты все, что только могли. Несмотря на «черную неблагодарность» сенаторов Тотила считал свою армию истинной защитницей римлян от «посягательств» Византии. Он даже назвал остготов «мстителями» византийцам за финансовые и хозяйственные притеснения. Тотила считал, что настоящий мир невозможен без союза сенаторов и остготов. Для этого Вечному городу нужно было немедленно сдаться королю58.

Письмо Тотилы приехало в Рим вместе с очередной группой отпущенных на свободу пленных византийцев. Прокопий сообщает, что сенаторы не изъявили желания идти на мирное соглашение с королем, что, очевидно, объясняется ужесточением остготской политики в аграрной сфере (в то время начались серьезные нападения на большие землевладения аристократов, поголовное переманивание сенаторских рабов в остготскую армию). Однако, Прокопий также отдельно ссылается на решение командира римского гарнизона Иоанна, запретившего сенаторам отвечать на любые обращения короля ${ }^{59}$. Как отмечает 3. В. Удальцова, «примирению Тотилы с римским сенатом в первую очередь, конечно, мешало то, что остготское правительство не могло отказаться от тех социально-экономических мероприятий, которые задевали интересы сенаторов, но в то же время обеспечивали Тотиле его успехи. Поэтому все попытки этого остготского короля сблизиться с сенаторами были обречены на провал, даже в тех случаях, когда сенаторы и не боялись мести императора за переход на сторону Тотилы» 60.

После неудачной попытки перемирия с сенаторами, Тотила

\footnotetext{
57 Marc. Chron., a. 545.

58 Procop. BG, III.9.7-18.

59 Procop. BG, III.9.20.

60 Удальцјова З. В. Там же. - с. 358.
} 
повернул пропаганду в обычное демагогическое русло. По ночам во многих местах Рима развешивались политические прокламации, которые призывали римлян к восстанию и к переходу на сторону «правителя Италии» Тотилье Прокопий сообщает, что распространением прокламаций, вероятно, занимались арианские священники ${ }^{62}$, которые, как это ни странно, оставались на подконтрольных византийцам территориях нетронутыми. Необходимо отметить: прокламации тотилы, как и массовое участие италийских зависимых крестьян $b$ остготской армии, рождали новую политическую идентичность на Апеннинском полуострове. Сегодня эта идентичность известна как итальянская. Конечно же, формирование современного итальянского этнического организма находилось на зародышевом этапе. Итальянцев ещзе не было. Но ощущуение возможности политического самоопределения появлялось. Оно было неотделимо от "римской идеи», но впервые показывало, что идея эта может быть понята иначе, чем элинистическое «всленское единство» (Ойкумена).

Позитивное восприятие прокламаций Тотилы итальянским населением очень показательно. Всего за два года власти византийцы сумели настроить итальянские массы против себя. Конечно же, остготы являлись государственными преступниками, борющимися против законной императорской власти. Конфликт не переставал быть гражданской войной. Но социально-экономическая обстановка внутри Италии способствовала предательской линии крупных землевладельцев. Персидские дела (намного более опасные, нежели бунт короля Тотилы) и продолжительная болезнь не позволяли императору приступить к организации мирного жизнеустройства в Италии. Тотила сумел воспользоваться этим уникальным историческим шансом и затянул разрушительную гражданскую войну еще на десять лет.

Падение Неаполя в начале 543 г. стало для Юстиниана неожиданностью. Ведь император лично распорядился организовать запасы продовольствия в этом важном портовом городе и отправил для обороны мощные восточноримские отряды. Неаполь считался ключом к Южной Италии и «междуостровного» Средиземноморья (морское пространство между Сицилией, Италией, Сардинией и Корсикой). Интересно, что именно Неаполь был избран остготами в качестве символической столицы. Тотила оттуда обращался к сенаторам и жителям Рима, призывая итальянских граждан поднять «антиэллинское» восстание.

Так или иначе, «всеобщее восстание» в значительной степени не

\footnotetext{
61 Procop. BG, III.9.20-21.

62 Procop. BG, III.9.21.
} 
началось из-за позиции римских патрициев, которые после длительных дискуссий в сенате, предпочли «римскую идею» (ортодоксальнохристианскую) идее «остготской Италии» (арианской). Весомые аргументы для римлян составила также нерушимая позиция полководца Иоанна и новость о прибытии Велизария.

Как мы помним, Велизарий, после майской победы 540 года, был отправлен на восточный фронт. Занимаясь организацией боевых действий против персов, Велизарий попал в опалу. По всей видимости, здесь играли роль не только внутренние интриги константинопольского двора, но и старое предложение Витигиса о провозглашении Велизария западным императором (540 г.). Комит Марцеллин писал: «Велизарий, отозванный с Востока для отражения врага, сам попал в опасное положение, впав в немилость, и был затем отослан обратно в Италию»63. Прокопии, $b$ свою очередь, сообщает, что Юстиниан и Феодора подозревали Велизария в присвоении больших сумм из сокровищнии, королей Гелимера и Витигиса. Именно поэтому Юстиниан вызвал Велизария к себе и предложил ему возврат полководческих полномочий только в случае, если Велизарий за свой счет соберет и экипирует экспедиционный корпус ${ }^{64}$. Велизарию пришлось согласиться. Летом 544 г. он организовал 4-тысячный фракийскоиллирийский отряд и, совершив переход через Далмацию, в декабре 544 г. вошел в Равенну.

Впрочем, прибытие Велизария добавило осажденным римлянам только моральные силы. Материальной мощи не прибавилось. Византийская армия продолжала терпеть тяжелые поражения. Остатки византийских войск на севере и юге сдавались Тотиле. Известен случай полного перехода сполетского гарнизона на сторону остготов. Возглавлявший этот гарнизон Иродион вступил в личный конфликт с Велизарием, предал противнику город, свое войско и перешел на службу к Тотиле. Это предательство Иродиона сильно ударило по военной кампании, вынуждая Велизария перейти к оборонительным действиям в Равеннском регионе. На севере Италии произошел также мятеж иллирийских солдат Велизария.

Весь 545 г. византийцы сдавали позиции в разных частях Италии. Комит Марцеллин писал, что в 545 г. «Тотила, опустошив Пицен, сражаясь, одержал победу при Ауксиме, а оттуда двинувшись через Тусцию разрушил Сполеций, захватил города Асизий и Клузий и осадил

\footnotetext{
63 Marc. Chron., a. 545.

64 Procop. BG, III.10.1.
} 
Перузию»65. Таким образом, предполагаемые наступательные действия прославленного полководца Велизария захлебнулись в самом начале.

Военная осада Рима остготами началась в декабре 545 г.66. Полтора года продолжались упорные бои вокруг «вечного города», стоившие мировой культуре множества памятников древнеримского зодчества и искусства. Второй раз за десять лет все пригороды Рима были сожжены, а население уничтожено. Положение осажденных оставалось очень плохим на протяжении всего времени сражения.

В первую очередь, Тотила, захватив Неаполь, Кум, Тибур, Лаций, Кампанию и Самний, лишил римлян возможности получать продовольствие сухопутным путем. Созданный остготами флот базировался теперь в Неаполе и на Эоловых островах, откуда совершал вылазки против византийцев. Папа Римский Вигилий успел перебраться на Сицилию, оставив во главе Рима диакона Пелагия67. Вигилий оставался верным императору и предпринимал всевозможные усилия для организации отпора остготам. Папа Римский лично оплатил и собрал группу кораблей с продовольствием, которые должны были тайно доставить еду по Тибру в Рим. Но остготский флот уничтожил эти корабли, а большая делегация папской свиты попала в плен. После допроса папские легаты были изрублены мечами. Тотила лично приказал отрубить обе руки приближенному к Вигилию епископу Валентину.

Когда последняя возможность получить продовольствие была утрачена, в Риме начались волнения. Жители города требовали сдачи города остготам, если в самое ближайшее время не подойдут византийские подкрепления ${ }^{6}$. Командир гарнизона Бесса фактически самоустранился от ведения дел и передал все полномочия Пелагию. Диакон начал переговоры с Тотилой, но остготский король отверг все предложения Пелагия. Для остготов больше не могло быть никаких условий со стороны римлян. Тотила считал, что теперь он могуществен как никогда и слушать римских аристократов больше не хотел. Тотила даже отказался обсуждать возможность возврата беглых рабов их старым владельцам ${ }^{69}$. Остготский король отослал посольство Пелагия назад в Рим, а сами остготы продолжили ожидание под стенами Рима, в котором осенью 546 г.

\footnotetext{
65 Marc. Chron., a. 545.

66 Procop. BG, III.13.1. Комит Марцеллин считает, что остготы приступили к штурму Рима в начале 546 г. - Marc. Chron., а. 546.

${ }^{67}$ Lib. Pont. V. Vigil., 8.

68 Procop. BG, III.16.7.

${ }^{69}$ Procop. BG, III.16.8-32.
} 
разразился страшный голод. Он и решил судьбу города... Как оказалось, полководцы Бесса и Конон спрятали часть продовольствия на личных складах и занимались спекуляцией, продавая вдесятеро дороже продукты питания знатным римлянам. И это тогда, когда «вся масса народа питалась преимущественно крапивой, которой много росло всюду вокруг укреплений, в развалинах на пустырях города; многие под давлением голода сами на себя накладывали руки, так как не моли уже найти ни собак, ни мышей, ни трупа другого какого-либо животного, которым бы они могли питаться»70.

Настоящая катастрофа произошла в ночь на 17 декабря 546 г., когда отряд голодающих исаврийцев открыл Азинариевы ворота остготам ${ }^{71}$.

Прокопий отмечал, что после устроенной германцами резни, в Риме осталось лишь 500 жителей «из простого народа»72. Огромное количество римлян убили, но еще больше граждан города вынуждены были покинуть его. Комит Марцеллин подчеркивает: «Тотила, благодаря измене исавров, вступил в Рим на 16-й день январских календ, стены его разрушил, дома сжег и имущество всех римлян захватил в качестве добычи; а самих же римлян, взятых в плен, отвел в Кампанию; после этого разграбления в течение 40 или более дней Рим был совершенно безлюден, и не оставалось там ни человека, ни какого-либо животного» 73 .

Тотила отдал город на полное разграбление своим войскам ${ }^{74}$. Убийства жителей города продолжались всю ночь с 16 на 17 декабря, о чем сообщает Прокопий. Он подчеркивает, однако, что остготы прекратили массовые убийства на следующий день, убивая только тех, кто попадался им навстречу. В целом, интересно, что Прокопий положительно относится к Тотиле, который, по его мнению, отдал приказ «остановить бойню» 75 . Он «запретил в дальнейшем готам убивать кого бы то ни было из римлян» ${ }^{76}$. Прокопий также пишет: «Из ценностей Тотила велел самое дорогое отобрать для себя, все же остальное позволил военным грабить, как они хотят. Много богатства нашел он в домах патрициев, но особенно много в логове Бессы; этот проклятый негодяй бессовестно собрал для Тотилы

\footnotetext{
70 Procop. BG, III.19.

71 Procop. BG, III.20.15-17.

72 Procop. BG, III.20.19-20.

73 Marc. Chron., a. 547.

${ }^{74}$ Iord. Rom., 380.

75 Procop. BG, III.20.25.

76 Procop. BG, III.20.25.
} 
груды золота, вырученного за продажу хлеба»77. Тотила собрал вокруг себя многих знатных римских пленников и, говоря им о византийцах, перешедших на сторону остготов, заявил: «Вы теперь будете на положении рабов, эти же, будучи друзьями готов, естественно, став им близкими, будут в дальнейшем нести те должности, которые вы несли прежде»78. С декабря 546 г. Тотила приступил к политике «решительного устрашения римской аристократии» ${ }^{79}$.

Как пишет Иордан, в 546 г. Тотила «опустошил всю Италию и занял Рим, разрушил укрепления всех городов, а всех сенаторов, ограбив, после того как был разрушен Рим, переселил в Кампанию» 80 . Остатки населения Рима были в полном составе переселены $b$ Кампанию, а сенаторы попали $b$ плен к Тотиле. Значительные успехи короля Тотилы сопутствовали реорганизации политической программы остготов.

Уже в 547 г. король отправил посольство к Юстиниану, которое возглавили диакон Пелагий и ритор Феодор. Это посольство предложило Юстиниану те же самые условия мира, на которых Италией правили Теодорих Великий и Амаласунтав․ Тотила говорил о том, что согласен признать верховную власть императора точно так же, как её признавали Теодорих и Амаласунта. В территориальном отношении Византия должна была уступить остготам всю Италию, Далмацию и Сииилию, а остготы взамен вновь считались бы де-юре частью Восточной Римской империи. Таким образом, речь шла о восстановлении права foedus ${ }^{82}$. В случае несогласия императора с его условиями, Тотила рискнул угрожать Империи убийством всех пленных римских сенаторов и началом военных действий в провинции Иллирик. Несмотря на эти угрозы, Юстиниан, помня о предательском отношении многих аристократов к Империи, ответил Пелагию отказом и выдвинул единственное условие мира - капитуляцию остготской армии. Как резюмирует Джон Джулиус Норвич, - «хотя падение Рима и не являлось серьезным поражением в стратегическом смысле, как символическое событие оно имело исключительное значение, и Тотила сразу же предложил византийцам мир. Но условия договора, предложенного готами,

\footnotetext{
77 Procop. BG, III.20.25-26.

78 Procop. BG, III.21.12-16.

79 Удальцьова З. В. Там же. - с. 379.

80 Iord. Rom., 379-380.

81 Procop. BG, III.21.18-25.

82 Procop. BG, III.21.18-25.
} 
были отвергнуты императором, и бои возобновились»83.

Противостояние с остготами в 546 г. развивалось очень плохо для восточных римлян, даже в сравнении с 542-543 гг. Византийцы потеряли большую часть Апеннинского полуострова. Остготы полностью переключили свое внимание на Калабрию и приморские части Южной Италии. Здесь собрались силы последних итальянских аристократов и сенаторов, осознавших губительные последствия сотрудничества с остготами. Борьба развивалась вокруг нескольких важнейших портовых центров - Гидрунта (Отранто) в Калабрии и Росцианы в Бруттии ${ }^{84}$. Исследования Э. Штейна доказывают, что сопротивление остготам на Юге Италии постепенно превратилось в общенародное движение ${ }^{85}$.

Еще в 543 г. во главе апулийских аристократов встал крупный землевладелец Туллиан. Он прямо обратился к византийскому полководцу Иоанну (закрывшемуся с гарнизоном в Гидрунте) с заверением в верности южноитальянских аристократов императору, но также и с требованием прекратить налоговые притеснения после победы над остготами ${ }^{86}$. Туллиан сумел объединить разношерстные социальные силы (землевладельцев, аристократов, свободных и полузависимых крестьян) в противостоянии остготам. В дальнейшем развитию провизантийского движения Туллиана способствовала политика, проводимая Тотилой в Риме и прочих регионах, которая была направлена на подавление ортодоксальной Церкви и уничтожение знати. Для организации подрывной работы в Калабрии и Бруттии Тотила присылал туда «многочисленные банды крестьян под командованием готских офицеров» 87 . Боевые действия перенеслись на самый юг Апеннин. Именно поэтому рывок Велизария к Риму был воспринят византийцами как большая победа. Сначала греческий отряд Мартиниана сумел захватить Сполето, а в апреле 547 г. византийский корпус Велизария смог ворваться в Рим и быстро овладеть городом.

Все авторы того времен подчеркнули огромное политическое значение захвата Рима88. Прокопий назвал действия Велизария «актом государственной мудрости», поскольку контроль над Римом позволял

83 Норвич Д. История Византии. История Венецианской республики. / Джон Норвич. - М.: АСТ: Астрель, 2011. - с. 88.

84 Procop. BG, III.22.22.

85 Stein E. Histoire du Bas-Empire. - t. II. - p. 579-582.

${ }^{86}$ Procop. BG, III.18.20-23.

87 Stein E. Histoire du Bas-Empire. - t. II. - p. 584.

88 Procop. BG, III.24.1; Marc. Chron., a. 547; Mar. Avent., a. 547; Iord. Rom., 380. 
говорить о возврате инициативы в руки византийцев ${ }^{89}$. Комит Марцеллин, вторя Прокопию, подтверждает широкий размах инженерных работ, предпринятых Велизарием во вновь обретенном Риме 90 . Полководцу понадобилось 25 дней усиленной работы для восстановления городской стены и организации крупного склада продовольствия ${ }^{91}$. Велизарий публично объявил населению Рима, что он пришел назад для восстановления былого величия Вечного города.

Узнав о захвате Рима, Тотила бросился к Вечному городу и попытался немедленно его вернуть ${ }^{92}$. Сильное поражение, которое Тотила потерпел под стенами Рима, активизировало остготскую оппозицию93. Для подготовки к новым атакам восточных римлян Тотиле пришлось оставить попытки захватить Рим и закрепиться с основными силами в Тусции ${ }^{94}$. В свою очередь Иоанн, совершил «дерзкую» вылазку из Южной Италии в Кампанию, где сумел спасти из остготского плена многих римских сенаторов и их семьи ${ }^{95}$. Это стоило Иоанну потери большей части Южной Италии. Армия Тотилы совершила масштабное вторжение на подконтрольные византийцам районы Лукании. Велизарию пришлось двинуться на помощь южанам, оставив в Вечном городе внушительный гарнизон ${ }^{96}$. В итоге, вылазка Велизария потерпела неудачу из-за внутренних противоречий в армии. Оставшийся в Риме гарнизон поднял мятеж и объявил о возможной сдаче Тотиле, если не будет выполнены требования по уплате задолженного жалования. Велизарию пришлось потратить много времени на решение этой проблемы, но ультиматум гарнизона, что очень интересно, был полностью принят, а сами мятежники амнистированы ${ }^{97}$. Однако, потеря византийцами Росцианы на юге, вновь позволила остготам взять инициативу в свои руки. Теперь они угрожали даже Сицилии. Вот почему Велизарий, потерявший благодаря этим поражениям политический авторитет, подал прошение об отставке (конец 548 г.). В ответ Юстиниан отозвал Велизария в Константинополь ${ }^{98}$. Джон

\footnotetext{
89 Procop. BG, III.24.1.

90 Marc. Chron., a. 547.

91 Procop. BG, III.24.7.

92 Mar. Avent., a. 547.

93 Procop. BG, III.24.29.

94 Procop. BG, III.24.31.

95 Procop. BG, III.26.12.

96 Procop. BG, III.27.4-17.

97 Procop. BG, III.30.7-8.

98 Procop. BG, III.30.3.
} 
Норвич, основываясь на «Тайной истории» Прокопия, считает, что это случилось вследствие нежелания Велизария нести ответственность за предрешенную капитуляцию остатков армии. Это безусловно играло определенную роль, но все же удовлетворение Юстинианом прошения полководца в большей мере объяснялось опасениями перед крупномасштабным персидским вторжением на восточных границах. Иордан также подчеркивает, что причиной отставки Велизария послужила смерть жены Юстиниана Феодоры (28 июня 548 г.), составлявшей протекцию для Антонины - жены Велизария99.

Пока Юстиниан обращал свои взоры к тлеющему персидскому конфликту, а византийские войска Италии находились в замешательстве, Тотила совершил разрушительные пиратские набеги на далматинское побережье Восточной Римской империи (весной 549 г.). Папа Вигилий постоянно обращался к Юстиниану с просьбами о помощи, но Юстиниан, узнав о новых заговорах и интригах, расцветавших в Константинополе, откладывал личное вмешательство 100.

Итальянская кампания вступила в самую жаркую для Константинополя фазу. Остготам удалось договориться с некоторыми другими германскими племенами, контролировавшими паннонскую низменность. Варвары начали организованные нападения по всей линии соприкосновения с Восточной Римской империей. Франки полностью оккупировали Венетию, гепиды вторглись в Дакию, славяне во Фракию, лангобарды осуществляли масштабные грабительские атаки по всей территории Далмации, а герулы разбили лагерь под Сингидуном (современный сербский Белград) ${ }^{101}$. Прокопий сообщал даже, что лангобардский король Ильдигис, объединив шесть тысяч гепидов и славян, объявил о своем подчинении Тотиле ${ }^{102}$. Говоря об остготском наступлении в Италии, набегах на Далмацию и Иллирик, персидской войне в Месопотамии, Прокопий написал горькие слова: «Так поделили между собой варвары Римскую империю»103.

Уже 16 января 550 г. остготы, пользуясь очередным предательством исавров, вновь захватили Рим ${ }^{104}$. Взяв под контроль Вечный город, король Тотила объявил о «возрождении» Рима. Теперь город вновь должен был

\footnotetext{
${ }^{99}$ Iord. Rom., 381-382.

100 Procop. BG, III.31-32.

101 Удальиова 3. В. Там же. - с. 394.

102 Procop. BG, III.35.20-22.

103 Procop. BG, III.34.1.

${ }^{104}$ Malal., p. 483.
} 
стать столицей. Тотила применял силу для заселения Рима, вселяя в заброшенные дома жителей окрестных провинций. В честь «восстановления остготской столицы» король провел большие игры. Это должно было не только придать авторитет королю или склонить итальянское население на сторону остготов, но и продемонстрировать, что теперь Тотила останется в Риме надолго. В связи с этим, Тотила несколько раз (в 550 г.) обращался к Юстиниану Великому с просьбой об установлении мира на условиях сохранения договоренностей Теодориха Великого (493-526) и Зенона (476-491), достигнутых в 488 году105.

Юстиниан не просто отказался от мирных предложений Тотилы, но и назначил нового итальянского главнокомандующего - Германа 106 . В ответ остготы совершили разрушительный набег на Сицилию. Но, как подчеркивает 3. В. Удальцова, сицилийский поход остготов выглядит весьма странным, поскольку располагая преобладающими силами и вполне использовав эффект неожиданности, остготы все же оставили остров и вернулись в Италию (с четырьмя сотнями военных кораблей, доверху нагруженными награбленным имуществом) 107 . Это можно объяснить только двумя причинами. Во-первых, армия Тотилы выдохлась за девять лет беспрерывной войны. Во-вторых, в отношении политики Тотилы была выстроена достаточно серьезная линия оппозиции. Теперь Тотиле приходилось считаться с серьезными противоречиями внутри остготской знати. Возможно, что именно поэтому Тотила чаще обращался к Юстиниану с безответными просьбами о заключении мира.

Осенью 550 г. двоюродный брат императора и итальянский главнокомандующий Герман умер. На эту должность был назначен его зять Иоанн ${ }^{108}$. В боевых действиях наблюдалось некоторое затишье, которое можно объяснить подготовкой обеих сторон к решающему сражению. В начале 551 г. 300 военных кораблей остготов напали на берег Эпира и разграбили остров Корфу. В ответ, византийцы нанесли сокрушительное поражение остготскому флоту возле Сенигаллии (Сены Галльской)109. Остготы предприняли высадку на византийских островах Сардиния и

105 Procop. BG, III.37.6-7; IV.24.4-5.

106 Герман, двоюродный брат Юстиниана Великого, женился вторым браком на Матасунте, дочери Евтариха и королевы Амаласунты, сестре короля Аталариха. Таким образом, род императора Юстиниана вступил в непосредственное родство с династией остготских королей Амалов.

107 Procop. BG, III.37.5.

108 Procop. BG, III.40.10.

109 Procop. BG, IV.23.41. 
Корсика. Для изгнания остготов Юстиниан направил ливийского наместника Иоанна Троглиту, который потерпел поражение на острове Сардиния (возле стен Кальяри) ${ }^{110}$.

Разгромив оплаченные Тотилой славянские отряды на Балканах ${ }^{111}$, Юстиниан Великий назначил новым главнокомандующим евнуха Нарсеса (весной 551 г.).

Благодаря хроникам Прокопия Кесарийского, Мария Аваншского, Агафия Миринейского, Иордана Готского биография Нарсеса хорошо изучена. Известно, что Нарсес родился около 478 г. на территории персидской Армении. В дальнейшем он попал в византийское рабство и был превращен в придворного евнуха. Постепенно Нарсес занял должность офицера и командира отряда императорских евнухов-телохранителей. В 531 г. он был послан Юстинианом на тайные переговоры с армянскими генералами, находившимися на персидской службе. В итоге армянская знать перешла на византийскую службу, а Нарсес получил должность главного казначея Восточной Римской империи. В 532 г., во время восстания в Константинополе против Юстиниана, главный казначей не только поддержал законного императора, но и рискуя жизнью переманил на его сторону городскую знать. Кроме того, Нарсес возглавлял отряд по уничтожению бунтовщиков. Юстиниан не забыл об этом и назначил Нарсеса в 538 г. на должность первого советника императора, сохранив за ним также титул главного казначея. Итальянское войско Нарсес возглавил в возрасте 74-х лет.

Нарсес почти на год задержался во Фракии, где командовал армией противостоящей славянскому вторжению112. Осенью 551 г. Нарсес был уже в Салоне (современном хорватском Сплите), занимаясь организацией и экипировкой итальянской экспедиционной армии. Юстиниан Великий официально объявил Нарсеса правителем и диктатором Италии на время военных действиї113.

Становится очевидным, что в 552 г. Юстиниан обладал уже достаточной твердостью власти для того, чтобы вернуться к решению итальянских проблем. Под руководством полководца Нарсеса 35 тыс. византийцев совершили поход в Италию по суше, проходя территории современных Хорватии и Словении. Начался далматинский поход Нарсеса 552

\footnotetext{
110 Procop. BG, IV.24.31-39.

111 Procop. BG, III.40.32.

112 Malal., p. 480.

113 Procop. BG, IV.21.5-6.
} 
года, итоги которого сыграли главную роль для дальнейшего поражения остготов. К этому моменту противоборствующие стороны прекрасно понимали, что новый виток боевых действий станет решающей битвой. Эту решающую кампанию в Италии подготовили разгром славян во Фракии и германских племен на Балканах в 551 г.

Для того, чтобы избежать возможного столкновения с франками и отрядами военачальника Тейи, Нарсес двинулся прямо вдоль Адриатического побережья (Истрия), где ему помогали соединения из равеннского гарнизона. Таким образом, прямо вдоль Адриатики двигалось огромное войско, которое численно уничтожило бы любую нападавшую силу. Это обезопасило Нарсеса от горных истрийских засад и позволило триумфально войти в Равенну ${ }^{114}$.

Прокопий сообщает о том, что в начале лета 552 г. «уныние духа и ума» охватило готов ${ }^{115}$. Внутриполитические конфликты привели к тайным переговорам между противниками Тотилы и командующим Гидрунтского гарнизона Пакурием. Понимая, что нарастание оппозиции зависит от передвижений Нарсеса, Тотила начал искать возможность сразиться с византийцами в открытом поле. «Момент истины» многолетнего конфликта настал в конце июня 552 г. Обе армии встретились на севере Центральной Италии, возле современного Гвальдо Тадино (тогда Тагина). Армии расположились друг против друга на землях долины Busta Gallorum, что означает «долина Галльских погребальных костров». Место для сражения было избрано очень символическое. Его название осталось со времен величайшего сражения римлян и кельтов (галлов), в результате которого кельтской (галльской) армии был нанесен непоправимый ущерб, а римляне подтвердили политический имидж правителей Европы ${ }^{116}$.

Новая битва на «Галльских погребальных кострах» начиналась очень долго. Несколько дней Тотила и Нарсес подогревали боевой дух своих воинов. Тотила всячески пытался оттянуть начало генерального сражения, так как ожидал прибытия двух тысяч конников. Король даже упражнялся перед строем остготской армии в искусстве верховой езды, параллельно отсылая посольства в обоз Нарсеса. Тотила дождался большого подкрепления и первый начал битву. Вся остготская конница ринулась в

114 Procop. BG, IV.26.24.

115 Procop. BG, IV.26.4.

$116 \mathrm{O}$ «Галльских погребальных кострах»: Hartmann L. M. Geschichte Italiens. / L. M. Hartmann. - Bd. I. - Gotha, 1897. - s. 321. Особенно обратите внимание на военное описание: Delbruck H. Geschichte der Kriegkunst. / H. Delbruck. - Bd. II. - Berlin, 1921. - s. 374-386. 
ряды византийцев, но была остановлена градом стрел. Искусство византийских лучников заставило остготов обратиться в бегство, которое по инерции увлекло за собой готовых атаковать пехотинцев. Весь день Тотила и Тейя провели в попытках восстановить ряды остготской армии, спасая остатки кавалерии. Вечером византийская армия, при деятельном участии лангобардских, герульских и славянских подразделений, нанесла непоправимый ущерб остготам. Нещадно уничтожались отряды византийцев-дезертиров, служившие Тотиле. Сам Тотила был ранен и перенесен верными остготами в городок Капрару. Здесь он и умер. Шеститысячный отборный корпус остготов сдался Нарсесу. Летописец Ландольф так описал исход сражения: «Когда готы почти все были перебиты, Нарсес убил короля Тотилу, который царствовал уже свыше десяти лет; окровавленные же его одежды и корона, украшенная драгоиенными камнями, были отосланы $b$ изарственный град Константинополь и брошены к ногам императора $b$ присутствии сената» 117.

Интересно, что византийцы решили удостовериться в смерти Тотилы. Специальный отряд занял Капрару, где труп Тотилы откопали, опознали и вновь похоронили. В это же время, остготская военная знать, выжившая на «Галльских погребальных кострах», отступила на север от реки По, где был созван новый военный совет. В большой спешке остготы избрали новым королем молодого военачальника Тейю118. Остатки военной казны Тотилы, Тейя решил использовать для покупки франкского участия в противостоянии. Иного выхода остготы уже не видели. Понимая, что генеральная победа Нарсеса принесет Византии долгожданный контроль над Центральной Италией, а гидрунтский гарнизон вот-вот очистит юг Апеннин, остготы обратились к франкским королям-Меровингам ${ }^{119}$.

Франки действительно выступили к Вероне, благодаря чему город остался под контролем остготов. Нарсес, не желая воевать в данный момент с франками, совершил переход к Риму, подчиняя своей власти все окрестные территории. Корпус Дагисфея вошел в Вечный город первым. Остатки остготского гарнизона закрылись в мавзолее Адриана, где остготам оказывали ожесточенное сопротивление сами византийцы еще в 546 г.

После кратковременного противостояния, в июле 552 г. Рим вновь оказался под контролем армии Восточной Римской империи. Нарсес совершил обряд триумфального вступления в город и выслал Юстиниану

\footnotetext{
117 Landolf., XVIII.19.

118 Mar. Avent., a. 553; Agn., 62.

119 Procop. BG, IV.33.7.
} 
символические ключи от римских ворот ${ }^{120}$. Потеря Рима озлобила окружение Тейи. Политическая коммуникация между остготским севером и югом была вновь прервана, только теперь остготы уже не имели достаточно воинов для быстрой мобилизации. В результате, остготы казнили триста сенаторских детей, взятых ранее Тотилой в заложники. Также остготы осуществили массовые убийства сенаторов и римских аристократов, земледельцев Кампании. Подразделения остготов-южан занимались физической ликвидацией всех, кто пытался вернуться в Рим или перейти на территории, подконтрольные Нарсесу ${ }^{121}$.

Король Тейя послал новых переговорщиков к Меровингу Теодебальду, который отказал ему в просьбе помочь вторжением. Для того, чтобы спасти родного брата, командовавшего осажденным в Кумах гарнизоном, Тейя с верными силами прорвался на юг. Остготский флот, тем временем, сдался византийцам. Благодаря этому Тейя перестал получать продовольствие морем, в остатках армии царили голод, паника и неразбериха. Остготские гарнизоны по всей Италии массово переходили на сторону Византии. Голодная «гвардия» Тейи заняла современный Монте Латтаро - «Молочную гору». В момент, когда большая часть остготских владений вновь была подчинена византийцами, флот полностью капитулировал, из Балкан и Сицилии прибывали все новые подкрепления императорских солдат, а голод истощал верных остготов, Тейя принял решение атаковать Нарсеса.

Нельзя не согласиться с утверждением 3. В. Удальцовой о том, что битва на Молочной горе в октябре 552 г., «принадлежит к наиболее героическим страницам истории войны в Италии»122. Вероятно, что это сражение должно войти в анналы мировой истории как отчаянная битва за доблестную и не голодную смерть. Прокопий написал: «Готов воодушевляло отчаяние, римляне же стыдились уступить более малочисленным противникам и выдерживали их натиск. Те и другие с яростью устремлялись друг на друга; одни искали смерти, другие славы»123. Октябрьская битва на Молочной горе решила не только судьбу преемника Тотилы короля Тейи, но и судьбу германского политического владычества в Италии. Вместе с Тейей погибли все остатки готской армии. Сам король беспрестанно находился в самой гуще сражения, на переднем

\footnotetext{
120 Procop. BG, IV.33.13-27.

121 Procop. BG, IV.34.2-6.

122 Удальизова 3. В. Там же. - с. 419.

123 Procop. BG, IV.35.21.
} 
краю нападающих. Он погиб от византийского дротика, после чего восточные римляне отрубили королю голову ${ }^{124}$. Несмотря на утрату вождя, остготы сражались до поздней ночи следующего дня.

Дополнительные сутки битвы значительно ослабили силы Нарсеса и он был вынужден согласиться на переговоры с остатками остготских войск. Между Нарсесом и делегацией остготов было заключено октябрьское соглашение 552 г., согласно которому Нарсес позволял остаткам остготской армии сохранить собственное имущество и оружие и навсегда удалиться на север от реки По. Кроме того, если проигравшие отказывались удаляться из Италии, они обязаны были признать себя подданными византийского императора и торжественно клялись никогда больше не вступать в военное противостояние с Империей. Этим соглашением с византийским военачальником, остготы официально признали себя мятежниками, восставшими против законной власти Юстиниана. В награду за свою исключительную храбрость на Молочной горе, они получали амнистию и прощение. Эти условия касались одной тысячи остготов, выживших во время битвы ${ }^{125}$. Летописец Агафий подчеркивает: «И одни из них, жившие раньше южнее реки По, отправились в Тусцию и Лигурию и куда кто захотел, другие же, переправившись на ту сторону, расселились как и раньше, по Венетии около тамошних укреплений и городов» ${ }^{126}$. Но, хотя «всем казалось, что все войны в Италии кончились»127, вскоре начался новый виток боевых действий - вторжение франков (552-555 гг.)...

Впрочем, дальнейшая история сопротивления ряда остготских отрядов на Севере Италии, подкрепленная масштабной интервенцией франков, алеманнов и бургундов, не позволяет говорить о возобновлении политических структур остготов. Их королество прекратило свое существование как де-юре, так и де-факто. Чисто юридически, Остготское королевство в Италии пало еще 30 апреля 535 г., когда король Теодат (534536) предательски убил королеву-наместницу Амаласунту (534-535). С этого момента правление остготов на землях провинции Италии, являлось незаконным. Оно нарушало нормы личного права императора. Остготы убили Амаласунту, а затем и других константинопольских чиновников (Фиделия, Репарата), за что должны были ответить по закону. Италия являлась частью Восточной Римской империи. Следовательно,

\footnotetext{
124 Procop. BG, IV.35.20-30.

125 Procop. BG, IV.35.37.

126 Agath., I.1.

127 Agath., I.1.
} 
неподчинение остготов византийским властям считалось преступлением. Для ликвидации вооруженного мятежа варваров-федератов, Византии понадобилось осуществить в Италии две изнурительные военные кампании, которые с юридической точки зрения обладали признаками внутренней войны. Первая фаза гражданского конфликта кончилась сдачей остготами Равенны в мае 540 г. Но развертывание остготских сил и дипломатическое лавирование Ильдибада (540-541) и Тотилы (541-552) обеспечили продолжение войны. Вторая фаза активизировалась в 542 г., когда остготы начали свое победное шествие. К 550 г. остготы восстановили контроль над основными территориями и только полная концентрация внимания императора на подавлении их мятежа позволила повернуть варварские полки вспять. Битва на «Молочной горе» в октябре 552 г., когда после гибели Тейи готская знать подписала с Нарсесом договор о завершении войны и признании власти Юстиниана, означала фактический конец Остготского королевства. Остготы отказывались от всей территории Италии, давали согласие на полное свое переселение в северные районы Апеннинского полуострова. Важным для нас фактом есть то, что остготы дали согласие на подчинение императору Восточной Римской империи. Несмотря на акценты о территориальном расселении готов, юридический смысл согласия состоял в признании остготов самих себя подчиненными Византии независимо от собственно территориальной локации ${ }^{128}$.

В рассматриваемом здесь контексте международно-правовой истории, представляют громадный интерес не только политические события и общий ход боевых действий, но и бытовое отношение итальянцев к византийской власти. Описывая общую канву событий, мы уже обращали внимание на интересную закономерность. Если во время первой итальянской кампании (536-540 гг.) римляне и латиноязычное население Италии оказывали огромную поддержку Велизарию и всем византийским подразделениям, то вторая итальянская война (541-552 гг.) показала, что итальянцы разделились, оказавшись на «баррикадах» различных противоборствующих сторон.

Итальянцы часто меняли даже политическую идентичность. Многие итальянцы римского происхождения называли себя готами, тогда как итальянцы готского происхождения записывались в «римляне».

128 О соглашении также см.: Agn., 79; Mar. Avent., a. 552, а. 553. 
Обработанные источники обращают пристальное внимание на факты многочисленных переходов с одной стороны на другую и наоборот. Нередкими, в этот раз (541-552 гг.), были случаи двойных и тройных дезертирств, предательств. Даже кадровые византийские военные неоднократно переходили на сторону Тотилы. В свою очередь, многие остготские военные сдавались византийцам. Некоторые исследователи считают этот факт признаком роста межэтнической розни в итальянском обществе (в частности, начальным этапом этнокультурной дифференциации римлян и греков). Из их работ следует, что бытовая ненависть латинян к грекам (единоверцам и сообщникам в деле строительства античной культуры) выступила катализатором зарождения итальянского этноса ${ }^{129}$. В связи с этим фактом, считаем нужным подчеркнуть: в процессе формирования той народности, которая сегодня населяет Апеннинский полуостров, в дальнейшем принимали активное участие не только италоримляне и оставшиеся на полуострове германцы, но и другие различные племена, в том числе лангобарды (особенно с 568-572 гг.)130, арабы ${ }^{131}$, нормандцы ${ }^{132}$, славяне (это касается в большей мере северного региона -

${ }^{129}$ Hartmann L. M. Geschichte Italiens. / L. M. Hartmann. - Bd. I. - Gotha, 1897. - s. 296330; Haury S. Die letzten Ostgothen. / S. Haury. - Monaco, 1915.; Romano G. Le dominazioni barbariche in Italia. / G. Romano, A. Solmi. - Milano, 1940. Часто акцентирует на бытовых этнокультурных противоречиях также и 3. В. Удальцова в своей монографии «Италия и Византия в VI веке». В целом, необходимо подчеркнуть, что попытка «произвести» итальянский этнос из «мировоззренческого столкновения» с греками-византийцами, характерна для всех историко-германистов. Поэтому её необходимо расценивать не столько как признак итальянской национальной исторической школы, сколько как философское наследие германского национализма в итальянской литературе.

130 K началу лангобардского вторжения в Италию (568-572 гг.) прошло всего шестнадцать лет с момента победы Византии (552 г.) в противостоянии с остготами.

131 Арабы завоевали грекоязычную Сицилию и часть Южной Италии в 827-840 гг. и контролировали остров и отдельные континентальные районы вплоть до второй половины XI века.

132 В 1059-1100 гг. нормандцы завоевали Сицилию и большую часть Южной Италии, заменив собственным герцогством арабское владычество. Основными языками юга Италии в эти годы были греческий, арабский и нормандский. Ни о какой итальянской идентичности еще не могло быть и речи. Центральная Италия, контролируемая папством, также не могла быть оплотом «итальянства». Папство рекрутировало чиновников-наёмников и клириков со всей Европы. Папы создавали тогда совсем другую идентичность - «католическую» (с греческого 
Венеции, Истрии). Вот почему говорить о появлении или активном формировании итальянской этнонациональной идентичности во времена кампаний Юстиниана Великого (527-565) некорректно.

Смена военно-политической принадлежности, часто практиковавшаяся в войне 541-552 гг., не выходила за рамки общепринятого политического процесса 133 (тем более, учитывая провинциальный статус Италии в Византии, речь шла о процессе внутриполитическом).

Знатью, командирами, вождями и солдатами руководила, прежде всего, жажда сохранить жизнь и занимаемое экономическое положение. Часто смена политической ориентации позволяла не только сохранить, но и приумножить материальные и нематериальные блага ${ }^{134}$. Тем более, что переход византийцев на сторону врага вовсе не означал отказа от формального подчинения императору. Ведь позже многие византийские дезертиры вернулись под знамена Нарсеса. Они не приносили присягу заново и не считались новобранцами. Они просто меняли политическую ориентацию, но не юридическую принадлежность. Эта тонкая грань хорошо видна в контексте второй итальянской кампании 541-552 годов. Она служит лишним подтверждением правового статуса итальянских событий как гражданской войны.

Итак, война 541-552 гг., по своему правовому положению, была гражданской войной внутри Римской империи, которая развивалась по типичной формуле «преступления и наказания». Сначала был факт неповиновения императорской власти, а затем последовало наказание и применение силы. Нарушение закона повлекло за собой санкцию государственного аппарата.

Несмотря на прокламации Тотилы и некоторые идеологические попытки обосновать «итало-готскую общность», итальянской этнонациональной идентичности не существовало. Был юридический факт - принадлежность к Восточной Римской империи. Был и политический

«кафолическая» переводится как «всеобщая»). К слову, одним из самых выдающихся пап в это время был Григорий VII Гильдебранд (1073-1085), создавший при помощи нормандцев Папскую республику и победивший немецких императоров.

133 Никто не станет спорить с утверждением, что смена идейно-политической или партийной принадлежности отдельных лиц, групп лиц или даже целых народов является обыденной частью политики.

134 И сегодня немногие способны устоять перед естественным человеческим инструментализмом. 
факт - лояльность к восточному императору и осознание единства всего Римского мира. Другое дело - территориальная идентичность. В системе понятий территориальной идентичности скрываются зародыши того, что сегодня принято называть национальным самосознанием. Не будем забывать: влияние географического фактора (месторазвития в терминологии Л. И. Мечникова, П. Н. Савицкого и Г. В. Вернадского) на общественное устройство и социальную психологию народов так велико, что весь исторический процесс в значительной степени является порождением и результатом этого влияния.

И политическая, и этническая идентичности напрямую зависят от «географического ареала» - территории, «месторазвития». К примеру, римская идея призывала народы Средиземноморья к психологическому самоотождествлению с политическими символами и атрибутами Императорского Рима, с величием и широтой его завоеваний. Но этническая история дает нам немало примеров разделенного (даже конфронтационного) проживания этнических групп в рамках одного пространства с присущим им отождествлением своего этнического «я» со всем этим пространством. Точно такой же показательный пример составляет Италия в эпоху ее повторного отвоевания Нарсесом (552 год).

Итальянцы, по праву крови, отождествляли себя со своей землей. Византийцы, по праву императорской власти и согласно с римской идеей, считали Италию своей землей. Остготы же называли Италию своей по праву силы. При этом, во всех трех случаях очень тяжело говорить о наличии какого-либо этнического ядра. Среди итальянцев проживало огромное количество греков, потомков кельтов и германцев. Среди византийцев также встречалось огромное количество людей с итальянским (чаще) или германским (реже) происхождением, а также массы славян, армян, даже гуннов. В среде остготов, на определенных этапах, становился заметным политический вес ругов, герулов. В остготской армии, без сомнения, сохранялись еще потомки племен, прорвавшихся на земли Западной Римской империи 31 декабря 406 г. и оставшихся в Италии после победы Одоакра (476-493 гг.). Поэтому нельзя согласиться с тем, что всего в одном десятилетии (540-550 гг.) были заложены какие-либо противоречия (в частности, этнопсихологические и социально-культурные), составившие в дальнейшем поле для конфронтации между условными Западом и Востоком. Такого закладывания противоречий не было, так как объективные причины цивилизационно-исторического и мировоззренческого характера не могли этого позволить. Сохранялось психологическое главенство «римской идеи». Но самое главное, что 
сохранялась сама Римская империя, которая вступила при императоре Юстиниане Великом (527-565) на вершину своего военно-политического могущества.

Editor-in-Chief Viktor Melnyk (Kyiv, Ukraine)

THE STRUGGLE OF BYZANTIUM FOR THE RIGHT TO OWN ITALY: HISTORICAL AND LEGAL CHARACTERISTICS OF THE WAR IN 541-552 AD

The change of military-political affiliation, often practiced in the war of 541-552 AD, did not go beyond the generally accepted political process (given the provincial status of Italy in Byzantium, it was a domestic political process). The noblemans and soldiers were led, first of all, by a thirst to preserve life and economic position. They did not take the oath again and were not considered recruits. They simply changed their political orientation, but not their legal affiliation. This fine line, analyzed in this article, is clearly visible in the context of the second Italian military campaign of 541-552 AD, which we characterize as the "struggle of the Eastern Roman Empire for the right to own the province of Italy". In any case, the war of 541-552 AD, according to its legal status, was a civil war within the Roman Empire, which developed according to the typical formula of "crime and punishment". At first there was a fact of disobedience to imperial power, and then punishment and the use of force followed. Violation of the law entailed the sanction of the state apparatus. The article refutes the sovereign status of Ostrogoth Italy in the period under review.

Keywords: Eastern Roman Empire (Byzantium), Personal Property of the Emperor, Byzantine Italy, Justinian the Great, King Totila (Baduila), Commander Narses.

главный редактор Виктор Мельник (Киев, Украина)

\section{БОРЬБА ВИЗАНТИИ ЗА ПРАВО ВЛАДЕНИЯ ИТАЛИЕЙ: ИСТОРИКО- ЮРИДИЧЕСКАЯ ХАРАКТЕРИСТИКА ВОЙНЫ 541-552 ГГ.}

Смена военно-политической принадлежности, часто практиковавшаяся в войне 541-552 гг., не выходила за рамки общепринятого политического процесса (учитывая провинциальный статус Италии в Византии, речь шла о процессе внутриполитическом). Знатью и солдатами руководила, прежде всего, жажда сохранить жизнь и занимаемое экономическое положение. Они не приносили присягу заново и не считались новобранцами. Они просто меняли политическую ориентацию, но не юридическую принадлежность. Эта тонкая грань, анализируемая в данной статье, хорошо видна в контексте второй итальянской военной кампании 541-552 гг., которую мы характеризуем как «борьбу Восточной Римской империи за право владения провинцией Италия». В любом случае, война 541-552 гг., по своему правовому положению, была гражданской войной внутри Римской империи, которая развивалась по типичной формуле «преступления и наказания». Сначала был факт неповиновения императорской власти, а затем последовало наказание и применение силы. Нарушение закона повлекло за собой санкцию государственного аппарата. Статья опровергает 
суверенный статус Остготской Италии в рассматриваемый период.

Ключевые слова: Восточная Римская империя (Византия), личная собственность императора, византийская Италия, Юстиниан Великий, король Тотила, полководец Нарсес, правовой статус гражданской войны.

головний редактор Віктор Мельник (Київ, Україна)

\section{БОРОТЬБА ВІЗАНТІЇ ЗА ПРАВО ВОЛОДІННЯ ІТАЛІЕЮ: ІСТОРИКО- ЮРИДИЧНА ХАРАКТЕРИСТИКА ВІЙНИ 541-552 pp.}

Зміна військово-політичної приналежності, що часто практикувалася в війні 541552 рр., не виходила за рамки загальноприйнятого політичного процесу (враховуючи провінційний статус Італії в Візантії, йшлося про процес внутрішньополітичний). Знаттю і солдатами керувала, перш за все, спрага зберегти життя і займане економічне становище. Вони не складали присягу заново i не вважалися новобранцями. Вони просто змінювали політичну орієнтацію, але не юридичну належність. Ця тонка грань, проаналізована в даній статті, добре простежується в контексті другої італійської військової кампанії 541552 рр. Ми характеризуємо іiі як «боротьбу Східної Римської імперії за право володіння провінцією Італія». У будь-якому випадку, війна 541-552 рр., за своїм правовим положенням, була громадянською війною всередині Римської імперії, що розвивалася за типовою формулою «злочину і покарання». Спочатку був факт непокори імператорській владі, а потім настав час покарання і застосування сили. Порушення закону спричинило за собою санкцію державного апарату.

Ключові слова: Східна Римська імперія (Візантія), особиста власність імператора, візантійська Італія, Юстиніан Великий, король Тотила, полководець Нарсес.

* Мельник Виктор Мирославович - главный редактор научного журнала «Анналы юридической истории», ассистент кафедры политологии философского факультета Киевского национального университета имени Тараса Шевченко, ученый секретарь Международного центра гражданской политологии при КНУ им. Тараса Шевченко, преподаватель кафедры философии и общественных наук Винницкого национального медицинского университета имени Н. И. Пирогова, член American Society for Legal History, член Национального союза журналистов Украины, член Международного союза журналистов (IFG). E-mail: melnyk1996ethnology@gmail.com. 
DOI 10.38129/Ann.Yur.Ist.2019.3.1.2.105

УДК 352.075.1

\title{
УТВОРЕННЯ І ПОЧАТКИ ФУНКЦІОНУВАННЯ СЯНОЦЬОГО ГРОДСЬКОГО УРЯДУ ТА ІНТЕГРАЦІЯ СЯНОЦЬКОЇ ЗЕМЛІ ДО СКЛАДУ ПОЛЬСЬКОГО КОРОЛІВСТВА В XIV-XV ст.
}

\author{
МИХАЙЛО ТУПИЦЯ (Львів, Україна)*
}

Гродські суди - це система судово-адміністративних установ, що утворювались навколо головного їх урядника - старости (capitaneus)1, та початково були судами першої інстанції для неосілої шляхти. Уряд старости, за твердженнями дослідників, був для середньовічного Польського королівства характерним і звичним інститутом ${ }^{2}$, котрий набув значної політико-юридичної ваги у період правління династії Пшемисловичів. Старости зазвичай були намісниками короля на місцях. Місцем здійснення безпосередніх повноважень старости вважався місцевий (локальний) замок - грод (лат. castrum); звідси походить назва установи.

Історіографію генези та хронології початку розвитку гродських судовоадміністративних установ у Польському королівстві розглянув та узагальнив дослідник М. Павліковський ${ }^{3}$. Джерела до вивчення сяноцького гродського судочинства (вживається також термін «судівництво») зосереджено здебільшого у виданнях «Актів гродських і земських». Узагальнюючи відомості про гродське судочинство, М. Павліковський робить висновок, що у новоприєднаних землях Польської корони протягом XIV ст. ще не було такого самого здійснення судочинства, як на інших землях держави. Реформування судової гілки влади було покликане консолідувати, інтегрувати та певною мірою централізувати Королівство Польщу. Відтак, важливим інструментом та кроком для забезпечення королівського авторитету на місцях була приватна спадкова власність на землю.

Сяноцька земля, як юридична одиниця адміністративнотериторіального устрою, ввійшла до складу Польського королівства

${ }^{1}$ Bardach J. Historia państwa i prawa Polski. Warszawa, 1973. T. 1. S. 124.

${ }^{2}$ Kutrzeba S. Starostowie ich początki i rozwój w XIV wieku. Kraków, 1903. S. 92; Bardach J. Historia państwa i prawa... - S. 256.

3Pawlikowski M. Sąownictwo grodzkie w przedrozbiorowej Rzeczypospolitej. Strzałków, 2012. S. 12. 
набагато раніше інших земель колишнього Галицько-Волинського князіства (в окремі періоди також і королівства).

За даними писемних джерел, академік М. Грушевський припускає, що Сяноцьку землю було формально включено до територіальної юрисдикції Корони Польської ще в 40-х роках XIV ст. ${ }^{4}$.

Окрім суто політичного аспекту, вважаємо, що серед причин приєднання Сяноцької землі до Польського королівства, очевидно був i географічний фактор, який полягав у безпосередній близькості цієї землі до столиці Королівства Польського - Кракова. Сяноцька знать охоче сприймала та навіть ініціювала 5 політико-юридичні зміни. Це стосується не лише досліджуваного нами періоду часу. Як відомо, Сянок був заселений німецьким католицьким населенням ще за княжих (галицько-волинських) часів, а в 1339 р. отримав німецьке міське (магдебурзьке) право. Під впливом настроїв і культурно-політичних орієнтацій, які привозили із собою західні колоністи-католики, враховуючи подальше приєднання до складу Польщі не за «правом меча», сяноцька руська шляхта почувалась доволі впевнено і могла дозволити собі самоврядування без королівського дозволу, що дефакто було надзвичайно позитивним явищем для держави як політикоюридичного організму6.

Зауважимо, що за княжої доби всю актову документацію писали староукраїнською мовою, але впродовж цілого XV ст. всі документи Сяноцького самоврядування були писані вже виключно латинською мовою iз деякими незначними вкрапленнями польської7. Це також варто взяти до уваги при розгляді питання про культурно-правову інтеграцію.

Земельні наділи та система судівництва - це прямо пов' язані речі (як у минулому, так і сьогодні). Дуже часто вони ставали причинами звернення до суду. Володіння та випадки легального відчуження земельних наділів шляхтою залишались надзвичайно гострими соціальними питаннями у другій половині XIV - першій половині XV ст. Протягом цього періоду королі багаторазово видавали привілеї щодо непорушності права на

\footnotetext{
${ }^{4}$ Грушевський М. Історія Украйни-Руси. Київ, 1993. Т. IV. С. 31.

5 Дорошенко Д. Нарис історії Украйни. Львів, 1991. Т. 1. С. 136.

6 Przyboś K. Wstęp / / Urzędnicy Wojewódstwa Ruskiego XIV-XVIII wieku (Ziemie Halicka, Lwowska, Przemyska, Sanocka): Spisy. Wrocław, 1987. S. 11; Крикун М. Земські уряди на українських землях у XV-XVIII ст. // Записки Наукового товариства імені Шевченка. Том CCXXVIII. Праці Історико-філософської секції. Львів, 1994. С. 65.

${ }^{7}$ Akta grodzkie $i$ ziemskie $z$ czasów Rzeczypospolitej Polskiej $z$ archiwum tak zwanego bernardyńskiego we Lwowie (далі - AGZ). Lwów, 1886. T. XI. S. 1-488; Tam że. T. XVI. S. 1-424
} 
володіння маєтками, які повторювали та уточнювали одне одного.

У вказаний хронологічний відтинок часу бачимо активне змагання королівської влади із шляхетськими правовими апетитами на теренах цілого королівства. Від Кошицького привілею 1374 р. ${ }^{8}$ до Нєшавського 1454 p. можна прослідкувати чітку тенденцію - шляхта змогла задовольнити свою потребу в недоторканності приватної спадкової власності на землю9. У контексті цих подій сяноцька шляхта не могла стояти осторонь. Однак, ї̈ правове становище було набагато міцнішим, аніж в шляхетському середовищі решти територій Галицької Русі.

Джерела до розкриття теми можна умовно розподілити за хронологічним принципом на кілька етапів. Визначені нами періоди в історії становлення польського права на руських землях показують, яким саме чином проводились інтеграційні процеси, а також характер і форми впливу політичних еліт на процедури інтеграції.

Перший етап: 40-ві роки XIV ст. - 1423 р. Цей проміжок часу має досить малу кількість джерел, що лише частково розкривають процеси інтеграції, але побіжні згадки про уряди та урядників демонструють процес початку рецепції польської системи самоврядування та судівництва.

Другий етап: 1423-1434 pp. Його можна умовно назвати «старостинським». Цей період представлений актовими документами, що ілюструють елементи судівництва в Сяноцькому гроді. Тематика актів $є$ доволі різноманітною та абсолютно не диференційована за тематичним принципом. В архівному «портфелі» присутні судові, і майнові, і фінансові, і земельні справи.

Третій етап: 1434 р. - кінець XV ст. Цей етап є завершальним у процесі правової інтеграції Сяноцької землі. В 1434 р. було остаточно реалізовано адміністративну реформу. Проте вона не поклала край побутуванню елементів місцевої руської (княжої) системи судочинства.

До кінця XV ст. процес інтеграції завершився і Сяноцька земля мала доволі типовий для Польщі гродський уряд. Із місцевої специфіки залишився поділ на гродові повіти, проте він стосувався цілого Руського воєводства. Конкретно, Сяноцький гродський уряд мав повноваження на теренах Сяноцької землі та повітів: Сяноцького, Динівського і Тичинського. При цьому, гродський судовий повіт називався Сяноцьким незалежно від

${ }^{8}$ Matuszewski J. S. Przywileje i polityka podatkowa Ludwika Węgierskiego w Polsce. Łódź, 1983. S. $62-70$.

9 Goźdź-Roszkowski K. Z badań nad Nietykalnością majątkówą polskiej szlachty. Postanowienia przywilejów z lat 1386 - 1454 // Studia z Dziejów Państwa i Prawa Polskiego. T. 10. Kraków, 2007. S. 30-32. 
того де засідав уряд в той чи інший хронологічний період ${ }^{10}$.

Периферійні території мали певні відмінності у функціонуванні як інститутів влади, так i господарчих форм економіки. Найдавніші документи із Сяноцького гродського уряду, що дійшли до нашого часу демонструють типове поєднання давнього руського та польського права. Хоч, у співвідношенні до корінних польських земель, Сяноцька земля була периферією, однак чітке визначення повноважень старост турбувало місцеву знать настільки ж сильно, наскільки й шляхту цілого королівства ${ }^{11}$. Як відомо, край у соціальних непорозуміннях поклав Вартський статут 1423 р. Його головні постанови (так звані чотири гродські артикули) полягали в обмеженні повноважень старостинського суду. До розглядання у старостинських судах відтоді належали справи, що стосувалися гвалту, викрадення, розбою на дорогах, нападів на маєтки та підпалів ${ }^{12}$.

Правовий фронтир Галицької Русі сприяв поєднанню руської та польської систем права, з перевагою першої над другою до 1434 р. Для прикладу, у стольному воєводському місті Львові впроваджують дві посади старости: генеральний руський староста та староста львівський. Крім цього староство існувало і в самому Сяноку ${ }^{13}$. Новоутворене Руське воєводство було «земельним», так як поділялось на землі. Ці землі відповідали юрисдикційним округам, тобто це були земські та гродські судові повіти. При цьому, судово-адміністративна ієрархія копіювала всі уряди столиці воєводства (Львова). Відмінним було лише те, що для цілого воєводства був лише один воєвода ${ }^{14}$, а сяноцький воєвода мав статус гродського.

Адміністративні нововведення на руських землях до реформи $1434 \mathrm{p}$. стосувалися здебільшого введенням посад, які пізніше стали фігурувати у земських урядах. Свідченням доволі жвавої інтеграції Сяноцької землі до Польського королівства виступає згадка про каштелянію в Сяноку

${ }_{10}$ Купчинський О. А. Земські та гродські судово-адміністративні документальні фонди Львова // Прикладна архівістика та спеціяльні історичні дисиипліни. Вибрані статті та матеріали. Львів, 2011. Т. 2. С. 500.

${ }^{11}$ Kutrzeba S. Starostowie... S. 118.

${ }^{12}$ Hencel A. Z. Starodawne prawa polskiego Pomniki: Starodawne prawa polskiego Pomniki poprzedzone wywodem historyczno krytycznym tak zwanego Prawodawstwa Wiślickiego Kazimierza Wielkiego w texcie ze starych rekopism krytycznie dobranym. Warszawa, 1856. T. 1. S. 319 .

13Szyszka J. Kształtowanie się podziałów terytorialnych Rusi Czerwonej na przykładzie ziemi lwowskiej // Średniowiecze Polskie i Powszechne. Katowice, 2011. T. 3 (7). S. 125.

${ }^{14}$ Крикун М. Земські уряди... С. 87. 
(«castellania Sanocensi») вже в 1359 p. ${ }^{15 !}$ Але посада каштеляна та ім'я самого урядника згадуються аж 7 листопада 1433 р.! В цьому документі Петро Смоліцький (Petro Smoliczky) притягується до суду через сплату неповної суми боргу братам Миколаю (Nicolaus), Млечку (Mleczko) та Кжиштку (Krzisztek), синам пана Пшедслава (Przedslaw) ${ }^{16}$. Казімєж Пшибось припускає, що згадуваний в актах від 12 жовтня 1412 p. Миколай де Блочішов (Mikołaj de Bloczischow) імовірно був каштеляном ще при Владиславі Опольському17.

Зміна у судочинстві означала зміну в правах та обов'язках місцевого населення, властиво аристократії. Галицькі еліти у складі Польського королівства відчували себе дещо приниженими. Після завоювання Галицької Русі місцева знать мала статус особистих слуг короля і змушена була виконувати королівські розпорядження під загрозою втрати земель ${ }^{18}$. Після боротьби за галицьку спадщину частина місцевої знаті була позбавлена свого попереднього статусу а частина хотіла отримати нагороду за підтримку польського короля. Так, за бажанням, а не всупереч знаті було ініційовано адміністративну реформу 1434 р., що включала зміну в місцевому судівництві.

Вище ми вже з'ясували, що шляхта Сяноцької землі мала дещо інакшу систему самоврядування до реформи 1434 р. ніж решта Галицької Русі. Місцевий судово-адміністративний орган був за своєю природою земським, але судові рочки проводили в замку і називали його гродським. Збережені дотепер акти дозволяють підтвердити цей факт. Не було поділу не конкретно земельні та конкретно кримінальні справи. Усі судові провадження записували до єдиної системи книг, що називались «Рочки Сяноцькі» («Termini Sanocenses»)19.

Склад Сяноцького суду до реформи містив досить незвичайні поєднання посад та їх ієрархії. Так у Сяноцькому гроді присутні наступні посади: староста, суддя, воєвода, писар земський, асесори ${ }^{20}$. При цьому звичайний, типовий гродський уряд мав у своєму складі старосту головного урядника. Суддю і писаря зазвичай призначав староста. Крім

${ }^{15}$ AGZ... - T. III. S. 25.

16 AGZ... - T. XI. S. 82.

17 Przyboś K. Wstęp // Urzędnicy Wojewódstwa Ruskiego XIV-XVIII wieku (Ziemie Halicka, Lwowska, Przemyska, Sanocka): Spisy. Wrocław, 1987. S. 10.

18 Бойко I. Органи влади і право в Галичині у складі Польського Королівства (1349-1569 рр.). Львів, 2009. С. 144.

${ }^{19}$ AGZ... T. XI. S. 1-90.

${ }^{20}$ Pietruski O. Liske X. Przedmowa // AGZ. Lwów, 1886. T. XI. S. VII. 
суддівських повноважень староста був намісником короля та охоронцем замку і підпорядкованої йому адміністративної округи ${ }^{21}$. Сяноцький староста був земельним і підпорядковувався старості руському, що був воєводським 22 .

Персонал Сяноцького дореформенного уряду нагадує поєднання гродського та земського урядів. Це $є$ суд земський, але в значенні відмінному від того, яке надавала земським судам реформа $1434 \mathrm{p}$. Звичайно, тут ще домінувало руське право. Староста тут $є$ головним урядником та суддею в широкому розумінні. На час своєї відсутності староста призначав заступника (vice-capitaneus). Коли староста Миколай Хжонстовський (Mikołaj Chrząstowski) 1432 р. виїхав у справах до короля, призначив замість себе Петра Смоліцького (Piotr Smolicki), який титулував ceбе vice-capitaneus та навіть capitaneus ${ }^{23}$. Йому підпорядковувався земський суддя, що розглядав усі справи, які надходили до установи. При цьому, він був радником старости, а не самостійним суддею. Самостійно суддя вів менш важливі провадження у час відсутності старости або за його смерті. У час відсутності або смерті судді староста міг за своїм бажанням призначати на цю посаду будь яку людину. Посада воєводи також була заснована на старому руському праві, але в XV ст. їі вже сприймали на польський манір, називаючи його воєвода гродський 24 . Швидше за все, означення воєводи «гродським» базувалось на тому, що він виконував свої обов' язки при замку та підкорявся владі старости. Підлеглість воєводи старості демонструється поведінкою старости щодо уряду. Певний час староста міг призначати на цю посаду земських дворян, вони часом мали статус особистих слуг старости. Подеколи староста не призначав сталого воєводи. Цього урядника в актах титулують vice-voyevoda або voyevoda protunc.

Повноваження старости на цьому етапі розвитку судової системи Польського королівства залежали від особи, щзо носила иеей титул. Традиційно адміністративні посади надавали добре знаним шляхтичам. При цьому, від заможності та розгалуженості клієнтської мережі конкретного старости залежав вплив старости, а звідси і цілого гродського уряду. Гродський уряд, як і інші уряди у Польському королівстві, формували в першу чергу не як юридичну установу, а як громадське коло людей, що їх очолював головний

${ }^{21}$ Крикун М. Земсъкі уряди... С. 81-82.

22 Там само. С. 92.

23 AGZ... T. XI. S. 72-74.

24 Hejnosz W. Jus Ruthenicale. Przeżytki dawnego ustroju spolecznego na Rusi Halickiej w XV wieku // Studya nad Historya Prawa Polskiego. Lwów, 1928. T. 12, ż. 1. S. 29-31. 
урядник, у даному випадку староста. Це була звичайна практика, оскільки більшість урядів формували з метою реалізації практичних «комунальних» потреб, а не для того, щоб було більше можливості отримувати вищий статус у суспільстві через володіння тим чи іншим урядом.

Деякі зловживання з боку шляхти у володінні земськими урядами спостерігаємо вже у XVI ст.

Після реформи постали дві окремі судово-адміністративні установи. Так сталось і на інших територіях Польського королівства. Відтак, ієрархія гродського уряду від найвищого до найнижчого урядників виглядала так: староста, гродський суддя, воєвода (гродський) і писар. Земський уряд очолив воєвода. Крім нього були: каштелян, гродський староста, суддя, підсудок і писар. В Сяноцькій землі попередній земський писар став писарем при земському уряді 25 .

Питання про статус воєводи залишається в історико-правовій науці досить нечітким. У документах воєвода згадується від середини XIV ст. Його відповідником у XIV ст. виступає уряд бурграбія. Уряд «Burgravio de Sanok» вперше згадується у 1359 р.26, а згадку 1373 р. Томка Вашоти як «Palatino nostro Sanocensi» дослідники вважають за потрібне потрактувати як бурграбія 27. Джерела показують, що уряд бурграбія виступав в ролі відповідника гродському воєводі, але від середини до кінця XV ст. встиг витіснити останнього із титулування урядника. Цей процес показує, щзо елементи місиевої правової традиції залишалися у Сяноцькій землі щзе доволі довго після впровадження польського права.

Отже, інтеграційні процеси в Сяноцькій землі відбувалися поступово, протягом близько півтора століття. Виклики, що постали перед польськими королями в справі консолідації та централізації королівства передусім реалізовувались через принцип верховенства права. Їх найяскравішим проявом стали зміни в судовій системі. Самоврядування та судочинство, як гілки виконавчої та судової влади, в той час ще були досить слабо диференційовані.

Документальна спадщина Сяноцького старостинського, а згодом гродського і земського урядів дозволяє нам розділити процеси політичної інтеграції цієї землі. Протягом всього періоду XIV-XV ст., що представлений у джерелах досить нерівномірно та неповно, помітно сталу тенденцію ненасильницького насадження нових принципів

\footnotetext{
${ }^{25}$ Крикун М. Земські уряди... С. 80; AGZ... T. XI. S. IX.

${ }^{26}$ AGZ... T. III. S. 27.

27 Tam że. T.VII. S. 16.
} 
самоврядування та їх охочого прийняття місцевими елітами. При цьому, сяноцькій знаті, після боротьби за галицьку спадщину, не загрожувала настільки велика небезпека втрати земельних наділів як елітам інших територій Галицької Русі.

Найдавніші збережені документи сяноцького суду не носять конкретної назви, що б відповідали певному статусу цього уряду. Та все ж схиляемося до думки, що уряд, за принципами формування більш схожий на гродський. Проте документація цього суду за тематикою може відноситись як до гродського так і до земського. Але, враховуючи прийняття Вартського статуту 1423 р., уряд і далі приймав та розглядав справи, що не були передбачені сферою його безпосередніх повноважень.

Отож, інтеграція Сяноцької землі до складу Польського королівства, через призму формування старостинського, а згодом і гродського уряду показує: цей процес мав чітко виражений політичний характер, охопивши терени не тільки локальної землі, але й цілого королівства.

\section{ЛIТЕРАТУРА}

1. Akta grodzkie i ziemskie z czasów Rzeczypospolitej Polskiej z archiwum tak zwanego bernardyńskiego we Lwowie. Lwów, 1872. T. III (1872), VII (1878), XI (1886), XVI (1894).

2. Hencel A. Z. Starodawnego prawa polskiego Pomniki poprzedzone wywodem historyczno krytycznym tak zwanego Prawodawstwa Wislickiego Kazimierza Wielkiego w texcie ze starych rekopism krytycznie dobranym. Warszawa, 1856. T. 1. $428 \mathrm{~s}$.

3. Бойко І. Органи влади $і$ право в Галичині у складі Польського Королівства (1349-1569 рр.). Львів, 2009. 625 с.

4. Грушевський М. С. Історія України-Руси. Київ, 1993. Т. IV. 535 с.

5. Дорошенко Д. І. Нарис історії України. Львів, 1991. 576 с.

6. Крикун М. Земські уряди на українських землях у XV-XVIII ст. Записки Наукового товариства імені Шевченка. Том ССXXVIII. Праці Історикофілософської секиії. Львів, 1994. С. 65-122.

7. Купчинський О. А. Земські та тродські судово-адміністративні документальні фонди Львова. Прикладна архівістика та спеціяльні історичні дисципліни. Вибрані статті та матеріали. Львів, 2011. Т. 2. 755 с.

8. Bardah. J. Historia państwa i prawa Polski. T. I: Do połowy XV wieku. Warszawa, 1965. $587 \mathrm{~s}$.

9. Kutrzeba S. Starostowie: ich początki i rozwój w XIV wieku. Kraków, 1903. $120 \mathrm{~s}$.

10. Pawlikowski M. Sadownictwo grodzkie w przedrozbiorowej 
Rzeczypospolitej. Strzałków, 2012. 144 s.

11. Przyboś K. Wstęp. Urzędnicy Wojewódstwa Ruskiego XIV-XVIII wieku (Ziemie Halicka, Lwowska, Przemyska, Sanocka): Spisy. Wrocław etc., 1987. 415 s.

12. Matuszewski J. S. Przywileje i polityka podatkowa Ludwika Wegerskiego w Polsce. Łódź, 1983. 252 s.

13. Goźdź-Roszkowski K. Z badań nad Nietykalnością majątkówą polskiej szlachty. Postanowienia przywilajów z lat 1386-1454. Studia z Dziejów Państwa i Prawa Polskiego. T. 10. Kraków, 2007. S. 15-32.

14. Szyszka J. Kształtowanie się podziałów terytorialnych Rusi Czerwonej na przykładzie ziemi lwowskiej. Średniowiecze Polskie i Powszechne. Katowice, 2011. T. 3 (7). S. 120-140.

15. Hejnosz W. Jus Ruthenicale. Przeżytki dawnego ustroju spolecznego na Rusi Halickiej w XV wieku. Studia nad Historią Prawa Polskiego. Lwów, 1928. T. $12, \dot{z} .1$.

MA Mykhailo Tupytsia (Lviv, Ukraine)

\section{ESTABLISHMENT AND BEGINNING OF THE FUNCTIONING OF THE SANOK GOVERNMENT AND THE INTEGRATION OF SANOK LAND TO THE POLISH KINGDOM IN XIV-XV centuries.}

The article tells about the acquisition of traditional Polish law in the territory of Galicia. The historiography of the problem and sources that have already been published, but not involved in this kind of research, are considered. The legal traditions of the Middle Ages in Central-Eastern Europe thus were able in some way to unite the rights of the two civilizations - the Catholic West and the Eastern Orthodox. The merging of the Rus and Polish legal cultures is examined on the example of the history of institutions, and in this case the main attention was drawn to the castle court. The castle courtwas chosen to see how the process of introducing Polish legal institutions to the territory of the Sanok Land of the Rus province was proceeding. In order to track down the process of integrating the legal system of the Sanok Land, we analyze the sources and look for the first mentions of those or other offices that were not inherent in the local law before. The reasons for the course and consequences of the integration of the Sanok Land are represented by thinking about the role of the local and alien aristocracy. Understanding the integration process is facilitated by the proposed periodization of historical sources of research. For its establishment, the principle of the availability of the sources and the specificity of their separation after the administrative reform of 1434 is taken. At the same time, the general picture of the composition of the Sanok castle courtis presented before and after the reform. The territory of jurisdiction and the scope of authority of this institution are also presented in this article. At the same time, it must be said that often in medieval practices there was a significant personal factor that was associated with the economic and political influence of a particular official.

Key-words: Sanok Land, Sanok Castle, Sanok Government, Galicia, Polish Kingdom. 
магистр Михаил Тупиця (Львов, Украина)

\section{СОЗДАНИЕ И НАЧАЛО ФУНКЦИОНИРОВАНИЯ САНОЦКОГО ГРОДСКОГО ПРАВЛЕНИЯ И ИНТЕГРАЦИЯ САНОЦКОЙ ЗЕМЛИ В СОСТАВ ПОЛЬСКОГО КОРОЛЕВСТВА (XIV-XV вв.).}

Статья рассказывает о рецепции традиционного польского права на территории Галицкой Руси. Рассматривается историография проблемы и источники, которые уже были опубликованы, но не привлекались к такого рода исследованиям. Автор утверждает, что правовые традиции Средневековья в Центрально-Восточной Европе смогли объединить правовые культуры двух цивилизаций - католической западной и православной восточной. Слияние русской и польской правовых культур рассматривается на примере истории юридических учреждений, и, в данном случае, основное внимание автора привлек гродский суд. Саноцкий гродский суд избран для того чтобы посмотреть, каким образом протекал процесс внедрения польских правовых институтов на территории Саноцкой земли Руского воеводства. Чтобы

проследить процесс интеграции правовой системы Саноцкой земли, проанализированы и найдены первые упоминания о тех или иных должностях, которые не были свойственны здешнему самоуправлению ранее. Причины, ход и последствия интеграции Саноцкой земли представлены размышлением о роли местной и пришлой аристократии (шляхетства). Понимание процесса интеграции облегчает предлагаемая автором периодизация исторических источников для данного исследования.

Ключевые слова: Сяноцкая земля, Сяноцкий замок, Сяноцкое самоуправление, Галиция, Польское королевство.

магістр Михайло Тупиця (Львів, Україна)

УТВОРЕННЯ І ПОЧАТКИ ФУНКЦІОНУВАННЯ СЯНОЦЬОГО ГРОДСЬКОГО УРЯДУ ТА ІНТЕГРАЦІЯ СЯНОЦЬКОЇ ЗЕМЛІ ДО СКЛАДУ ПОЛЬСЬКОГО КОРОЛІВСТВА В XIV-XV ст.

Стаття розповідає про впровадження традиційного польського права на території Галицької Русі. Розглядається історіографія проблеми і джерела, які вже були опубліковані, але не залучалися до такого роду досліджень. Автор стверджує, що правові традиції Середньовіччя в Центрально-Східній Свропі змогли об'єднати правові культури двох цивілізацій - католицької західної і православної східної. Злиття руської та польської правових культур розглядається на прикладі історії юридичої установи - гродського уряду. Іродський уряд обраний автором для того, щоб подивитися, яким чином протікав процес впровадження польських правових інститутів на території Сяноцької землі Руського воєводства. Щоб відслідкувати процес інтеграції правової системи Сяноцької землі проаналізовані джерела та знайдені перші згадки про посади, які до того часу не були властиві тутешнім юридичним практикам. Причини, хід та наслідки інтеграції Сяноцької землі представлені роздумами про роль місцевої та прийшлої аристократії (шляхти).

Ключові слова: Сяноцька земля, Сяноцький замок, Сяноцьке самоврядування, 
Галичина, Польське королівство.

* Тупиця Михайло Васильович - магістр історичних наук історичного факультету Львівського національного університету імені Івана Франка. E-mail: mr.tupytsia@gmail.com. 
DOI 10.38129/ Ann.Yur.Ist.2019.3.1.2.116

УДК 342.156

\title{
РОЗВИТОК ІДЕЇ НАРОДНОГО СУВЕРЕНІТЕТУ ЗА ДОБИ СЕРЕДНЬОВІЧЧЯ: ДЕРЖАВНИЙ ТА ЦЕРКОВНИЙ ВИМІРИ
}

\author{
ВЛАДИСЛАВ САСІН (Київ, Україна)
}

Народний суверенітет - це один із базових принципів демократії, що $є$ предметом жвавих політико-юридичних дискусій та обговорень. Як i будь-яка теоретико-методологічна категорія юриспруденції, народний суверенітет має свою термінологічну історію й нероздільно пов' язаний із боротьбою за права і свободи людини, формуванням уявлень про громадянство й підданство, становленням демократичних режимів в європейському та загальносвітовому вимірі, багатьма іншими процесами, що відображають сутнісні характеристики демократичного дискурсу.

Європейське Середньовіччя зіграло чималу роль для розвитку категорії народного суверенітету, попри загальновизнану оцінку Раннього та Високого Середньовіччя як періодів, в яких про демократію та прояви народовладдя годі й говорити. Формування ідей народного суверенітету в епоху Середньовіччя, на думку відомого дослідника, випускника Імператорського університету імені Святого Володимира М. Палієнка, викликано багатьма чинниками: рецепцією римського права та правової спадщини Давнього Риму, особливостями становлення державності в германців, феодальним договірним характером відносин між сюзереном і васалом, князями і станами (верствами), уявленнями про початковий природний стан, де не існувало дуалістичного інституту пануванняпідкорення, аналізом спадщини Аристотеля та рефлексією античної демократії ${ }^{196}$.

Поговоримо більш детально про всі ці чинники.

Феодалізм став однією 3 характерних рис Раннього та Високого Середньовіччя, а вже за часів Пізнього розпочинаються процеси розладу феодальних відносин і постає етап формування національних держав у вигляді абсолютних монархій. Сутність феодалізму відображають відносини сюзерен-васал, які носили договірний характер. На своєму

196 Н. Палиенко. Суверенитет: Историческое развитие теории суверенитета и ее правовое значение. - Ярославль: Тип. Губ. правл., 1903. - 591 с. 
початку, феодалізм, в певній мірі, постав протилежністю ідеї єдиної імперії. Саме подолання феодалізму стало тим моментом, який дозволить в майбутньому (XVI ст.) говорити вже про категорію державного суверенітету. На перший погляд, здається, що феодальний лад за своєю суттю $є$ запереченням ідей народного суверенітету, адже пропонує нам лад, в якому «королі мали себе за сюзеренів - верхівку піраміди особистої залежності. Місцеві володарі привласнили собі право на особу та майно своїх підданих право чинити суд, карати, збирати податки, отримувати ренту і послуги» 197.3 цим важко не погодитися, але саме феодалізм, а точніше процеси його розладу, потягнули за собою розвиток самоврядування в місті й церкві, які фактично ознаменовували руйнування вертикальних зв'язків і натомість утвердження горизонтальних відносин у певній спільноті. 3 іншого боку, цей закономірний процес підтверджує теза відомого дослідника Середньовіччя Джона Гіттінгера про те, що «групове життя - це один із найголовніших внесків Середньовіччя. Місцеві групи й міські громади, комуни і гільдії,

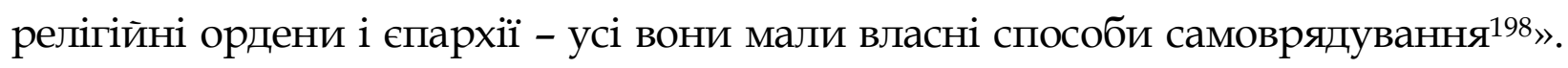
Енщиклопедія політичної думки Міллера також зазначає, що зі спробами кодифікувати і стандартизувати узвичаєну феодальну практику на всіх теренах усталювався корпоративний погляд на суспільство - його практичною основою стало утворення й розвиток ремісничих цехів, а теоретичною - узаконення римським правом самоврядних автономних громад ${ }^{199}$, що є фактичним підтвердженням думки Джона Гіттінгера.

Феодальні володарі намагалися підпорядкувати собі навколишні церкви і монастирі, розташовані на їхній території й призначати на місця єпископів і абатів «своїх людей» - людей, які дуже часто не дбали про свої обов'язки і служіння. У той же час, відбуваються процеси реформування в церковному житті, що призводять до докорінних змін в чернецтві, а надалі - у відносинах між місцевим феодалом і локальними монастирями. Так, у 910 році ченці монастиря в Клюні склали хартію, яка забороняла втручатися феодалу в справи монастиря і церкви, постановила їхню незалежність від будь-якої влади, окрім папської та надала їм право самостійно обрати абата зі свого кола, що перетворювало цю організацію середньовічного громадянського суспільства на юридично автономну громаду ${ }^{200}$.

197 Міллер Д. Енииклопедія політичної думки. - Київ: «Дух і літера», 2000 - С. 358.

198 Единбурзъкий погляд на історію демократії від давніх часів до майбутніх можливостей / за ред. Б. Айзехена та С. Стоквела. - Харків: Фоліо, 2017. - С. 193. 199 Міллер Д. Енциклопедія політичної думки. - Київ: «Дух і літера», 2000 - С. 358. 200 Там само. 
Тома Аквінський також захищав нові релігійні ордени і стверджував, що люди мають право об'єднуватися задля доброї справи, перетинаючи межі станів і класів.

Виходячи за межі усталеної традиції та привілеїв, Тома Аквінський захищає нові релігійні ордени за допомогою права на заснування «нових форм свободи об'єднань $201 »$. Такий спосіб релігійного життя апелював до первісного християнства, де життя членів громади зводилося до рівності, участі кожного вірного в житті спільноти та відсутності процесів панування-підкорення.

Утворення гільдій також постало взірцем самоуправління.

Як «професійна група», гільдія могла встановити власні стандарти допуску до професії. Гільдії не просто не підлягали контролю з боку політичної влади феодала-землевласника, а й ставали альтернативною моделлю спільного обговорення суспільно значущих питань. Вплив гільдії на процеси життєдіяльності усього суспільства (суспільство, як зазначалося раніше, являло собою «соттипіtas соттипіtatem», себто федеративну групу різних груn) полягав у їхній ролі в управлінні містом, а в деяких випадках наприклад, у Марселі - в безпосередньому здійсненні повноцінного міського самоврядування 202 .

Такого виду корпораціями можна вважати і феномен середньовічних університетів, які виникають наприкінці XI століття і стають достойною заміною церковним школам. Кожен член університетської спільноти (наприклад, в Парижі чи Оксфорді) отримував дозвіл на викладання від церкви. Так відбулося зростання кількості світського духовенства, яке мало монополію на писемність і систематизовану освіту. До університетських спільнот долучалися і представники жебрацьких католицьких орденів (бенедиктинці, францисканці, домініканці); університети ставали платформою, де виховувалися покоління королівських чиновників і радників. Саме за їхнього сприяння відбулася рецепиія римського світського права, ідей Цицерона про суспільство як організм, а надалі (XII cm.) постають концепиіі природного права, правових засад, lex regia (права управляти) та права справедливості 203 .

Рецепція римського права, яке стало сутнісною основою для просування ідей народного суверенітету, представництва, секуляризації в

${ }^{201}$ Hittinger R. Reasons for a Civil Society. T. Fuller and J. Hittenger (eds), Washington, DC: Catholic University of America Press, 2001. - pp. 11-23.

202 Единбурзький погляд на історію демократії від давніх часів до майбутніх можливостей / за ред. Б. Айзехена та С. Стоквела. - Харків: Фоліо, 2017. - С. 196. ${ }^{203}$ Міллер Д. Енциклопедія політичної думки. - Київ: «Дух і літера», 2000 - С. 358. 
Середньовіччі здійснювалася світськими правителями на противагу канонічному праву, що постало у результаті Григоріанської реформи XI ст., котра викликала за собою появу Граціанового систематичного зводу канонічного права. До складу джерел канонічного права увійдуть закони, відібрані з постанов багатьох церковних соборів, теологічних тверджень отців церкви та папських декретів, що їх видавало папство в намаганні реформувати та централізувати католицьку церкву. Водночас, германські імператори, особливо Фрідріх I (Барбаросса), заохочували усебічне рецепіювання римського права, адже воно, у сукупності 3 пізніше відкритими працями Аристотеля про етику і політику, стало засобом, за допомогою якого було докорінно змінено економічний, політичний та філософський лад Середньовіччя ${ }^{204}$. Як висновок, римське і канонічне право від кінця ХІ ст. стають антиномічною дихотомією, в якій розвивається імператорська i папська полеміка щодо розуміння співвідношення державної і церковної влади, сутності людини та соціального виміру природи загалом.

Принцип римського права - «те, що стосується усіх, має встановлюватися усіма» - відіграв важливу роль в обгрунтуванні ідеї народного суверенітету відомими англійськими правниками Джоном Солсбері та Генрі Бректоном.

У творах Солсбері, а особливо в трактаті «Policraticus» (1156-1159), відбулося відродження багатьох ідей изицеронового вчення про республіку, природний закон та справедливість; цей доробок вважається одним 3 найкращих до часів, коли європейцями були наново відкриті й рецепійовані твори Аристотеля.

Солсбері розмежовує поняття доброчесного правителя і тирана: «Між тираном і правителем є та одна чи головна відмінність, що останній кориться законові і править народом згідно з законом, вважаючи себе слугою народу. Саме завдяки закону стає добрим його намір посісти найвидатніше й найчільніше місце в керуванні справами держави ${ }^{205}$ ». I надалі підводить питання до того, чи є король підвладним тим законам, які існують у республіці. «Хай обілювачі правителів... трублять, що король непідвладний законові і що будь-які його воля й бажання, не лише в установленні законів відповідно до моделі рівності, а цілковито звільнені від усіх обмежень, мають силу закону... Я все-таки твердитиму, що королі підвладні цьому законові 206 ».

\footnotetext{
204 Міллер Д. Енциклопедія політичної думки. - Київ: «Дух і літера», 2000 - С. 358. 205 Себайн Джордж Г., Торсон Томас Л. Історія політичної думки. - К., 1997. - С. 237. 206 Міллер Д. Енциклопедія політичної думки. - Київ: «Дух і літера», 2000 - С. 358.
} 
Отже, з цих слів можна зрозуміти, що для Дж. Солсбері саме закон є тим важелем, який утримує державця від того, аби він скотився до рівня тирана. I установлення цього закону, з одного боку, лежить на Божому провидінні (закон - це дар Божий і саме на духовенстві лежить обов'язок навчати йому правителів), а з іншого - на народі, адже існує природне знання морального закону (aeguitas), подібне до поглядів Цицерона, яке людина може пізнати за допомогою власної розумової діяльності.

Погляди Генрі Бректона (пом. 1268 р.) ще глибше пронизані розумінням народу як джерела влади у державі. У його творі «Про закони і звичаї Англії» зазнчається, що королівська влада має реалізовуватись, насамперед, у судочинстві, а не в законотворчості. Творення законів, у свою чергу, лежить на усьому суспільному загалі: король лише висловлює згоду 3 тими законодавчими актами, які є ухваленими народом 207.

Ідеї народного суверенітету огортали не тільки світську сферу тогочасних правників, але були наявні і серед церковних мислителів. Так, наприклад, ще під час боротьби за інвеституру (XI століття) німецький монах Манегольд Лаутенбазький зазначав, що влада світських правителів, імператора і короля, має делегований характер (vocabulum officii). Тому у випадках порушення умов цієї угоди про делегування повноважень, народ навіть наділяється правом позбавити монарха його титулу: «тирана народ може позбавити корони як негідного пастуха».

Упродовж XII століття література також досліджує питання про підвалини імператорської влади та про ï відносини з народом. Юристи Болонської школи, на основі римського права, визнали верховну владу германських імператорів абсолютною та отриманою внаслідок законної спадкоємності від римських імператорів. У літературі зазначаються i демократичні ідеї, що народ не передає саму владу імператорові, а лише передає право здійснювати цю владу, залишивши саме право на владу в себе. Влада імператора має делегований характер. Звідси випливало право народу видавати закони, які були б обов' язковими, як для імператора, так і для народу. Також противники папства, спираючись на норми римського права, виводили світську владу з початкової влади народу, щоб у такий спосіб заперечити вчення папства та їхніх каноніків про те, що земна влада встановлюється духовним чином і, відповідно, папою208.

Сама ідея про папу як представника Христа сприяла появі паралельного

${ }^{207}$ Міллер Д. Енциклопедія політичної думки. - Київ: «Дух і літера», 2000 - С. 42.

208 Н. Палиенко. Суверенитет: Историческое развитие теории суверенитета и ее правовое значение. - Ярославль: Тип. Губ. правл., 1903. - С. 68-69. 
уявлення про політичного лідера як представника народу. Це стало причиною того, що упродовж ХІІІ ст. постали два дихотомічні підходи щодо розуміння держави і суверенності у ній. Перша з них зазначала, що джерелом усієї земної влади є Бог, а отже, монарх є помазаником Божим, він є єдиним каналом влади у державі. Натомість другий підхід мав демократичний характер і наголошував на «суверенності народу, яка розглядалася у рамках системи комунального, гільдійного чи міського самоврядування або делегування вихідної колективної влади довіреній особі, що уособлює рішення корпоративної більшості 209 ». Джерелами такого підходу, з одного боку, є звичаї давньогерманського народу, який залишав за групами індивідів правовий інститут протистояння самодержавству короля, який згодом був легітимізований через норми рецепійованого римського права; 3 іншого боку, цей підхід став наслідком розвитку тих урбаністичних регіонів, де формувалася торговельна й ремісницька буржуазія, - спершу для забезпечення просування торгівлі та пов'язаною 3 нею практик, але згодом вона розвинулася до рівня автономного самоврядування, а врешті і до колективного управління спільнотою та містом, як, наприклад, це відбувалося у Франції (Марсель) та Італії (Генуя, Венеція тощо).

В тогочасних справах церкви також спостерігалися процеси, які вказують на інститути представництва та народного суверенітету. Так, абатства, соборні збори каноніків та жебрацькі ордени, про які зазначалося вище, продовжували проводити вибори абатів, єпископів і представників відповідних об'єднань; вся власність вважалася колективною, тож єпископ чи навіть папа діють лише як розпорядники майна 210.

Німецький юрист, професор Отто фон Гірке вважав, що таке громадське i духовне представництво походить також від звичаїв германських племен: вождь представляє плем'я, отже, вождь представляє громаду своїх підданих ${ }^{211}$. Отже, право громади перетворилося на доктрину народного суверенітету. Збори представників також могли стати суб'єктом реалізації права громади. «Персоніфікація громади, - як доцільно вказує Джон Гіттінгер, - стає для неї інструментом колективної дії212».

У XIII столітті європейцями було наново відкрито твори Аристотеля і саме поняття аристотелівського «спільного блага», разом із

209 Міллер Д. Енииклопедія політичної думки. - Київ: «Дух і літера», 2000 - С. 359.

210 Там само.

211 Hattersley A. F. A Short History of Democracy. Cambridge: Cambridge University Press, 1930. - P. 96.

212 Единбурзъкий погляд на історію демократї від давніх часів до майбутніх можливостей / за ред. Б. Айзехена та С. Стоквела. - Харків: Фоліо, 2017. - С. 198. 
вищезазначеними чинниками, сприяло утвердженню римського приниипу публічного права, відповідно до якого король є слугою народу, щзо керує задля спільного блага.

Праці Аристотеля, а особливо «Політика», стали переломним моментом у формуванні політичної філософії XIII-XV століть та продемонстрували різність поглядів на феномен народного суверенітету та місця народу у здійсненні влади у державі. Одна частина філософів, яких визнавала ортодоксальна католицька церква, на чолі яких стояв Тома Аквінський намагалися пов'язати античну спадщину Аристотеля 3 середньовічною дійсністю католицької церкви. Тома Аквінський спромігся пов'язати віру і розум в одну всеохопну систему знань, у якій чіткого розмежування світської і духовної сфери не відбувалося. У його концепті суспільство уявлялося як сукупність відносин панування-підкорення. Перевагу Тома Аквінський надає монархії і зазначає, що вона має бути обмеженою, але, на жаль, не вказує в який саме інституційний спосіб відбувалося обмеження влади короля. Про демократію і ідею народного суверенітету Томою сказано небагато, але він допускав існування демократії, тобто встановлення закону народом, у випадку відсутності законодавця «висвяченого Богом ${ }^{213}$ ».

Натомість тлумачі Аристотеля в аверроїстській 214 традиції (Дунс Скот, Вільям Оккам, Марсилій Падуанський та інші), розглядали крізь призму філософії Аристотеля незалежність та самодостатність двох мечів (за концепцією папи Геласія I). Сфери віри і розуму були розрізненими, чітко визначалися функціональні обов'язки держави як світського початку, i церкви як духовного. Це стимулювало і інший погляд на демократію й народний суверенітет.

Найбільшим загостренням суперечки між духовною і світською владою стали конфлікти між королями Франщії й правителями Німеччини 3 римськими папами. Перш за все, слід згадати полеміку Боніфація VIII 3 Філіпом IV Вродливим з приводу суверенітету влади. Надалі ця полеміка постала знову, коли папська курія почала чинити вплив у непростій ситуації королівських виборів у 30-х рр. XIV ст. У цій суперечці прихильники обох сторін за допомогою аристотелевого вчення і Святого Письма намагалися обгрунтувати верховенство влади папи, 3 боку прихильників «папського

213 Н. Палиенко. Суверенитет: Историческое развитие теории суверенитета и ее правовое значение. - Ярославль: Тип. Губ. правл., 1903. - С. 69.

214 Аверроїзм - від імені арабського філософа Ібн-Рушда, що транскрибувалося латиною як «Аверроес». 
імперіалізму» (Гілезій Римський «Про владу церкви» 1301 р.), та короля, з боку тих, хто віддавав перевагу імператору та розмежовував духовну і світську сфери (Йоанн Паризький («Про владу короля і папи»), Марсилій Падуанський («Захисник миру»)). Саме в працях прихильників другого шляху постають ідеї народного суверенітету і тих принципів, які заклали підвалини розвитку політичної філософії наступних епох - Відродження та Нового часу.

Так, наприклад, публіцист-домініканець Иоанн Паризький стверджував, що держава виникла в природний спосіб, і періоду заснування держави передувало винайдення приватної власності.

Бог наділив усіх людей спільною землею, згодом люди за допомогою розвитку праці розподілили ії на приватну власність, а правителі постають, як запобіжник виникнення розбрату між власниками цієї землі. Власність підданих державця підпадає під його юрисдикцію і без передання ними своїх прав на приватну власність. Саме тому правителі обираються 3 народної згоди. У випадку, якщо відносини між підданими і правителем втрачають довіру через те, що правитель дбає не про загальні інтереси, а про свої власні, народ може скинути такого правителя як негідного своєї служби «спільному благу» 215 . Тобто Йоанн Паризький наголошував на понятті права індивіда на приватну власність, яку він має ще до встановлення будь-якої світської чи духовної влади.

Його думки продовжив i поглибив Марсилій Падуанський, сформувавши контекстуальну концепцію політичної спільноти аристотелівського взірця.

Марсилій пише: законодавець, або перше й по-справжньому ефективне джерело закону, - це народ, або всі громадяни, або переважна частина їх, який наказує або ухвалює згідно зі своїм вибором чи волею на загальних зборах і в усталених виразах, що певні громадянські дії людей бажані або їх слід уникати під загрозою штрафу чи земного покарання 216 ». Причиною дії станів $є$ законодавець, legislator humanus, який теоретично визначає та підтримує їх, навіть якщо передає урядові власні владні повноваження. Народ необмежений носій державної влади. «У цьому вислові, - як зазначає німецький дослідник Гайнц Рауш, - Марсилій визнає себе причетним до ідеї народного суверенітету - вчення, яке постало з часів боротьби за інвеституру; завдяки йому воно дістало найвідоміше формулювання (хоча саме поняття

215 Міллер Д. Енциклопедія політичної думки. - Київ: «Дух і літера», 2000 - С. 153.

216 Себайн Джордж Г., Торсон Томас Л. Історія політичної думки. - К., 1997. - С. 237. 
як таке ще не оформилося)» 217. Марсилій вирішив показати, що папи і духовенство мають бути підвладні не тільки у світських справах, але й в духовній сфері усьому народові і світському володареві, який діє в інтересах цього народу. Одна 3 тез політичної теорії Марсилія проголошувала єдиним законним джерелом будь-яких політичних перетворень та владних повноважень тільки народ. Народові відводилася місія розробляти закони або власноруч, або через обраних ним представників, і саме народ має обирати «належний уряд, а за необхідності і розпускати його»218. Отже, Марсилій Падуанський проголошує ідею народного суверенітету та початки теорії представництва, адже тільки народ може обирати тих, хто володарюватиме над ним. Управлінці мають бути відповідальним перед народом і діяти відповідно до його інтересів.

Також до розвитку ідеї народного суверенітету долучився й англієць Вільям Оккам, хоча його доктрина дещо поступається розвитку народовладдя в політичній теорії М. Падуанського. Оккам стверджував, що джерелом будь-якого верховенства $є$ народ, саме члени спільноти мають природну владу створювати закони і призначати правителів. Але через недосконалість світської сфери мирське верховенство має бути законним навіть у тому разі, якщо воно є тиранією. У політичній сфері він по суті ігнорував владу народу, який від початку має дати свою згоду суверену, стверджуючи, що одного разу призначений правитель перебирає на себе усю владу до тих пір, поки його правління залишається корисним і сприятливим для загального добробуту 219 . Натомість Вільям Оккам більше доклав зусиль до розвитку ідей народного суверенітету та демократизму в тогочасній римо-католицькій церкві. Він $є$ одним 3 авторів, так званої «соборної теорії». Оккам порушує проблему папського абсолютизму та догмату про непогрішимість папи римського. На його думку, генеральний собор, тобто збори де б були представлені духовенство і миряни, має стати взірцем в управлінні римо-католицької церкви, а отже, саме таке управління мало здійснюватися на демократичних ідеях представництва та суверенності усіх. Вільям Оккам трансформував норму римського права «те, що стосується усіх, має примайтися усіма» - в норму канонічного права, адже тільки в такий спосіб можна було б зупинити початок розколу церкви, сучасником якого був Оккам.

217 Класики політичної думки від Платона до Макса Вебера: Пер. 3 нім. - Київ: Тандем, 2002. - C. 127.

218 Міллер Д. Енциклопедія політичної думки. - Киӥв: «Дух і літера», 2000 - С. 232. 219 Там само. С. 264. 
Великий розкол, який тривав в католицькій церкві протягом 1378-1417 років відзначився протиборством двох течій - консиліаристської, яка відстоювала ідею пріоритету рішень собору над рішеннями папи римського та абсолютистської, що наполягала на верховенстві та абсолютності влади папи римського відносно духовної сфери.

Цікавою для розвитку ідеї народного суверенітету в епоху Середньовіччя $є$ перша лінія, адже фактично вона породила вчення про конституційне обмеження духовної і світської влади папи римського собором. Ідеї консиліаризму зародилися ще в Ранньому Середньовіччі, але свого розвитку i вивершення набули в період Високого i Пізнього Середньовіччя. Так, цікавим для нас є те, що чотири Латеранські собори, які проводилися відповідно 1123 р., 1139 р., 1179 р., 1215 р., продемонстрували, що собор має владу скасовувати рішення навіть самого папи римського. Останній Латеранський собор 1215 р. за папи Інокентія III, в свою чергу, забезпечив демократичне обрання пасторів та доступ до освіти для бідних студентів 220.

Надалі відображення цих ідей бачимо і в ідеях Йоанна Паризького (визначав умови, за яких можна було б усунути папу римського та відстоював право церковного собору як верховного органу влади, якщо він складається 3 усіх членів церкви), Марсилія Падуанського (вибори місцевого духовенства та єпископів народом, засудження олігархічної тиранії папства), Вільяма Оккама (ідея про Генеральний собор як про модель урядування в римо-католицькій церкві, розробка інституційних обмежень сваволі папства).

Вагомою постаттю в консиліаристському русі був Микола Кузанський. Саме в його апеляціях до папства акцентується увага на тезі про необхідність існування собору як органу, який має в дискурсивний спосіб вирішувати вектор розвитку, догматику й місце церкви. Його демократизм щодо церковного життя римо-католицького християнства пронизаний ідеєю народного суверенітету, ба навіть початками теорії суспільної угоди.

У творі «De concordatia catholica», який М. Кузанський представив на Базельському соборі 1431 р., він зазначає: Таким чином, оскільки за природою всі люди вільні, будь-яка влада, що перешкоджає підвладним чинити зло, обмежуючи їхню свободу колом добрих вчинків через страх покарання, йде лише від гармонії й від згоди підвладних, незалежно від

220 Единбурзъкий погляд на історію демократї від давніх часів до майбутніх можливостей / за ред. Б. Айзехена та С. Стоквела. - Харків: Фоліо, 2017. - С. 198. 
того, закріплена влада писаним законом чи живим законом, яким є правитель. Бо якщо за природою люди однаково сильні чи однаково вільні, то справжня й усталена влада одного над іншим, коли правитель має таку саму природну владу, могла бути встановлена лише завдяки вибору й за згодою інших, власне як закон запроваджується через згоду»221. Звідси можна зробити висновок, що Кузанський вважає, що королем править певний договір, який пов'язує його з народом, і тільки слідування йому робить цю особу королем. Ця ідея перегукується 3 тезою англійського правника Бректона про те, що саме закон уможливлює існування короля.

Хоча консиліаризм зазнав поразки на межі XV-XVI століть, його ідеї стали наріжним каменем, на якому вибухне Реформація 3 іï ідеями демократизму та поділу церковної влади між усіма членами християнської спільноти ${ }^{222}$.

Отже, ідея народного суверенітету в епоху середньовіччя формувалася у суперечливих умовах. 3 одного боку - через перехід феодалізму до стадії абсолютизму в державному вимірі, а 3 другого шляхом антиномічного дискурсу державно-церковних відносин, у яких дві сторони намагалися легітимізувати власні інтенції та посягання на суверенітет - і державний, і церковний.

\section{ЛITEPATУРА}

1. Единбурзъкий погляд на історію демократї від давніх часів до майбутніх можливостей / за ред. Б. Айзехена та С. Стоквела. - Харків: Фоліо, 2017. - 639 с.

2. Класики політичної думки від Платона до Макса Вебера: Пер. 3 нім. - Київ: Тандем, 2002. - 584 с.

3. Міллер Д. Енщиклопедія політичної думки. - Київ: «Дух і літера», 2000 - 472 c.

4. Палиенко Н. Суверенитет: Историческое развитие теории суверенитета и ее правовое значение. - Ярославль: Тип. Губ. правл., 1903. - 591 с.

5. Рассел Бертран. Історія західної фрілософіï. - К., 1995. - 759 с.

6. Себайн Джордж Г., Торсон Томас Л. Історія політичної думки. - К., 1997. 838 c.

7. Hattersley A. F. A Short History of Democracy. Cambridge: Cambridge University Press, 1930.

8. Hittinger R. Reasons for a Civil Society. T. Fuller and J. Hittenger (eds). Washington, DC: Catholic University of America Press, 2001.

BA Vladyslav Sasin (Kyiv, Ukraine)

221 Себайн Джордж Г., Торсон Томас Л. Історія політичної думки. - К., 1997. - С. 237.

222 Міллер Д. Енциклопедія політичної думки. - Київ: «Дух і літера», 2000 - С. 185. 

AGES: STATE AND CHURCH VIEWS

The article deals with the political and historical development of popular sovereignty in the Middle Ages. The reasons of revival of interest were analyzed according to the idea of popular sovereignty. Also were analyzed the characters of feudalism relations between suzerain and vassal, reception of Roman law as well as the works of Aristotle, customary law of German tribes have been used in the understanding of idea of popular sovereignty. A lot of works of medieval lawyers and philosophers (John of Salisbury, Henry de Bracton, Marsilius of Padua, William of Ockham, John of Paris, Thomas Aquinas) were analyzed in the article.

Keywords: Democracy, Popular Sovereignty, Middle Ages, Two-Swords Theory, Conciliarism, Roman law.

бакалавр Владислав Сасин (Киев, Украина)

\section{РАЗВИТИЕ ИДЕИ НАРОДНОГО СУВЕРЕНИТЕТА В СРЕДНИЕ ВЕКА: ГОСУДАРСТВЕННОЕ И ЦЕРКОВНОЕ ИЗМЕРЕНИЯ}

Статья посвящена историко-политологическому анализу развития категории «народный суверенитет» в эпоху европейского средневековья. Проанализировано возрождение интереса к идее народного суверенитета. Указано на развитие идеи народного суверенитета через призму государственной и церковной жизни. Определены места феодальных отношений (сюзерен-вассал), рецепции римского права и аристотелевского теоретического наследства, обычного права варварских племен в процессе формирования идеи народного суверенитета. Также проведен комплексный анализ работ известных средневековых юристов (Джон Солсбери, Генри Бректон) и философов (Фомы Аквинского, Марсилия Падуанского, Иоанна Парижского, Вильяма Оккама, Гилезия Римского и других) и характер описания ими народовластия. Исследованы различные социально-политические феномены в жизни европейских средневековых городов, государств и церкви, повлиявшие на становление идеи народного суверенитета в эпоху средневековья. Сделан общий вывод о влиянии средневековых подходов понимания народного суверенитета на формирование раннемодерной теории суверенитета и демократии.

Ключевые слова: демократия, народный суверенитет, эпоха Средневековья, «теория двух мечей», консилиаризм, римское право.

бакалавр Владислав Сасін (Київ, Україна)

РОЗВИТОК ІДЕЇ НАРОДНОГО СУВЕРЕНІТЕТУ ЗА ДОБИ СЕРЕДНЬОВІЧЧЯ: ДЕРЖАВНИЙ І ЦЕРКОВНИЙ ВИМІРИ

У статті наводиться історико-політологічний аналіз розвитку категорії «народний суверенітет» в епоху європейського середньовіччя. Проаналізовано причини відродження інтересу політиків та юристів до ідеї народного суверенітету. Вказано на розвиток ідеї народного суверенітету крізь призму державного і церковного життя й основних віх державно-церковних відносин в епоху 
середньовіччя. Визначено місце феодальних відносин (сюзерен-васал), рецепції римського права та аристотелевої теоретико-методологічної спадщини, звичаєвого права варварських племен у формуванні ідеї народного суверенітету. Також проведено аналіз творчого доробку правників (Джона Солсбері, Генрі Бректона) і філософів (Томи Аквінського, Марсилія Падуанського, Йоанна Паризького, Вільяма Оккама, Гілезія Римського та інших), охарактеризовано місце народовладдя в їхніх творах. Досліджено соціально-політичні феномени життя середньовічних європейських міста, держави й церкви, що спричинили вплив на дефініцію ідеї народного суверенітету в означену епоху. Зроблено загальний висновок про вплив середньовічних політичних підходів щодо народного суверенітету на формування новочасного i ранньомодерного розуміння суверенітету й демократії.

Ключові слова: демократія, народний суверенітет, епоха середньовіччя, «теорія двох мечів», консиліаризм, римське право.

* Сасін Владислав Олександрович - бакалавр політології філософського факультету, бакалавр юриспруденції юридичного факультету Київського національного університету імені Тараса Шевченка. E-mail: vladyslav.sasin@gmail.com. 


\title{
НАУКОВИЙ ЖУРНАЛ \\ «АННАЛИ ЮРИДИЧНОЇ ІСТОРЇ̈»
}

Том 3, Випуск 1-2, січень-червень 2019 р.

\section{ANNALI URIDICNOI ISTORII \\ ISSN 2520-2553}

\author{
Головний редактор - В. М. Мельник \\ Колективний керівний орган - Наукова редакційна рада \\ Контактна електронна адреса: annali.yur.istorii @gmail.com \\ Сайт: http://legalhistoryjournal.com.ua
}

Рекомендовано до опублікування Міжнародним центром громадянської політології при

Київському національному університеті імені Тараса Шевченка, протокол №2 від 28.06.2019

Підписано до друку 28.06.2019 p.

Журнал видається за сприяння

Міжнародного центру громадянської політології

при Київському національному університеті імені Тараса Шевченка та

Львівського медієвістичного клубу

при Львівському національному університеті імені Івана Франка

Всі рукописи, зауваження та пропозиції приймаються в електронному вигляді.

Контактна адреса - annali.yur.istorii@gmail.com. 